\title{
Dél-alföldi regionális ifjúsági helyzetelemzés 2005
}




\section{JANCSÁK CSABA - TARNAY IsTVÁN - VAJDA ÁRPÁD - ZÁVOGYÁN MAGDOLNA}

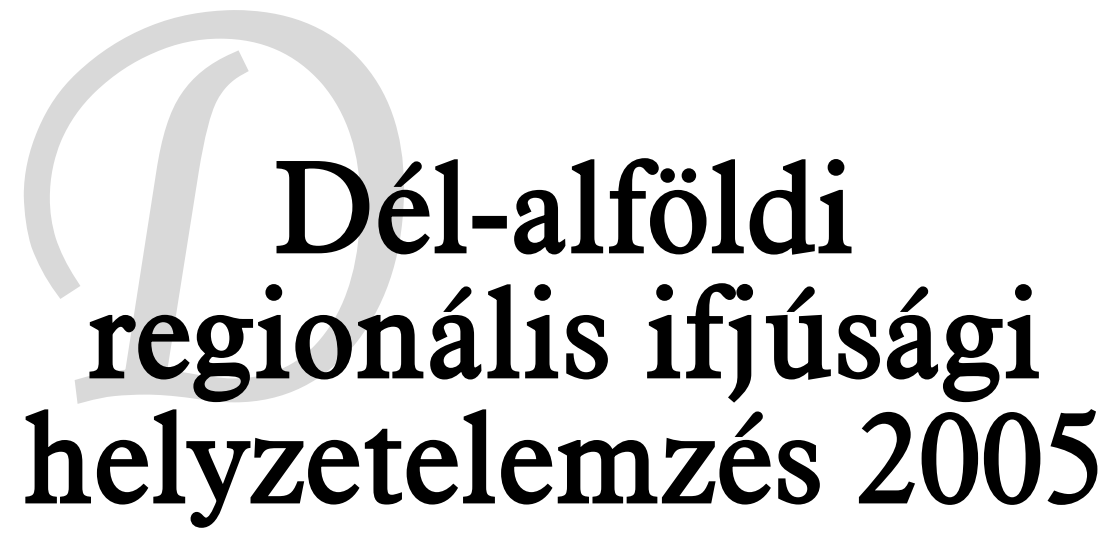

- kutatás közben -

HÁLÓZAT A SZABAD INFORMÁCIÓÉRT ALAPÍTVÁNY SZEGED, 2005 
A kötet megjelenését támogatták

Duna-Körös-Maros-Tisza Eurorégió Ifjúsági Szövetsége

Európai Ifjúsági Kutató-,

Szervezetfejlesztő és Kommunikációs Központ

Ifjúsági, Családügyi, Szociális és Esélyegyenlőségi Minisztérium

Mobilitás Dél-alföldi Regionális Ifjúsági Szolgáltató Iroda

Nemzeti Civil Alapprogram

\author{
Lektorálta \\ BENE TAMás \\ GÁBOR KálmáN \\ KÁTAI GÁBOR \\ Matiscsák AtTila \\ A fejezeteket irták \\ JANCSÁK CSABA II. \\ TARNAY ISTVÁN I., II.2 \\ VAJDA ÁRPÁD III, IV \\ Závogyán Magdolna III, IV \\ A boritót Pacsika Rudolf alkotásának felhasználásával \\ MAJZIK ANDREA tervezte \\ Kiadta

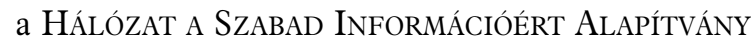 \\ Felelős kiadó: DöBÖR ANDRÁs \\ Tipográfia: FORRÓ LAJOS \\ Nyomta: BÁBA NYOMDA \\ Felelős vezető: Dr. MAJZIK IsTVÁN
}

ISBN 9632196562

(c) Jancsák Csaba, Tarnay István, Vajda Árpád, Závogyán Magdolna szerzók, 2005

(C) Hálózat a Szabad Információért Alapitvány, 2005 


\section{Tartalom}

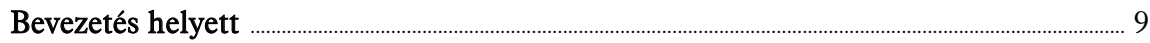

I. A dél-alföldi régióban élő fiatalok helyzete ……………………………………………………...... 12

1.1 Népességszám …….............................................................................................................. 12

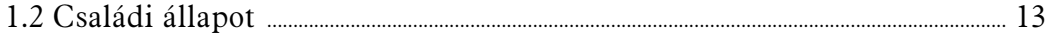

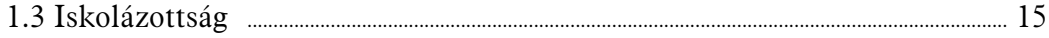

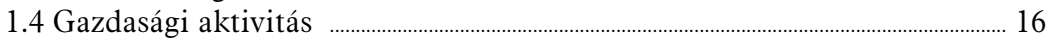

1.5 Anyagi helyzet ................................................................................................................. 18

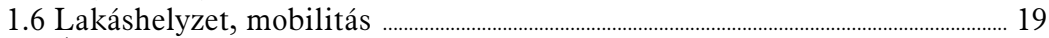

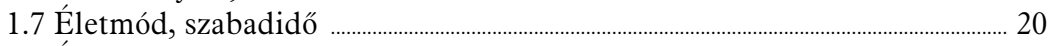

1.8 Értékrend, jövőkép ............................................................................................................ 22

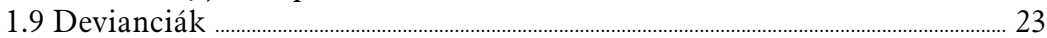

2. Civil szervezetek, közélet .................................................................................................................. 24

2.1 Információs társadalom ........................................................................................................... 25

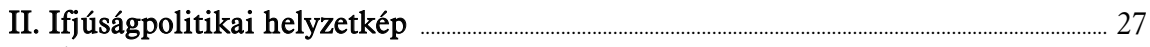

1. Intézményrendszer, szolgáltatások (régió-megye-település) ……………………....... 27

1.1 RISZI tevékenységei, szolgáltatásai, fejlesztési lehetőségei .............................. 27

1.2 HISZI-k tevékenységei, szolgáltatásai, fejlesztési lehetőségei ........................ 34

1.3 Közösségi terek (Ifjúsági házak, teleházak, klubok, ifjúsági fesztiválok) .......... 36

1.4 Drogprevenciós szolgáltatások, intézmények .......................................................... 39

1.5 A régió településszerkezete, regionális jellemzők .................................................... 42

2. A dél-alföldi régió önkormányzatainak ifjúságpolitikája ................................................ 48

2.1 Ifjúsági intézményrendszer ............................................................................................. 50

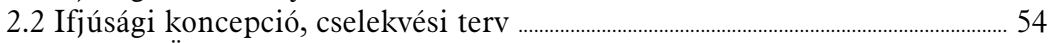

2.3 Ifjúsági Önkormányzat .............................................................................................................. 55

3. A régió civil szervezeti adottságai (régió-megye-település) ...………………………... 56

3. 1. Az ifjúsági civil szervezetek (számosságuk, tevékenységük, kapcsolataik, lehetőségeik), illetve az ifjúságot segítő civil szervezetek: tevékenységük, kapcsolataik, lehetőségeik ........................................................................ 56

4. A régió forrásfelvétele az ifjúsági munka területén 2000-2004 .................................... 61

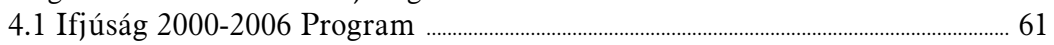

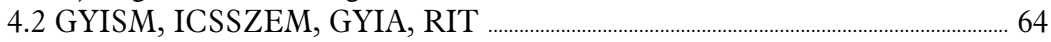

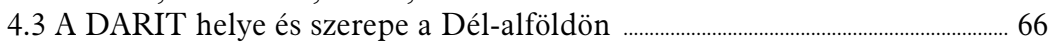

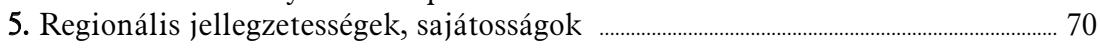

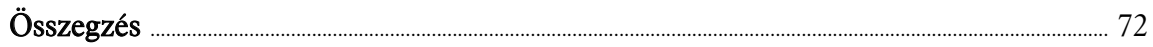

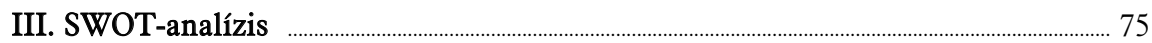

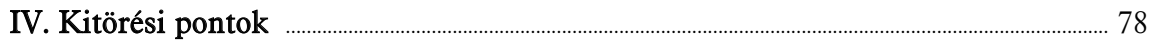

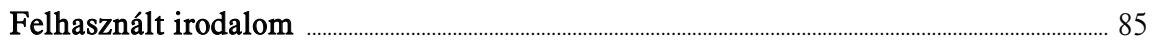

A kötet szerzői ………………………………………………………………………………………………….. 86

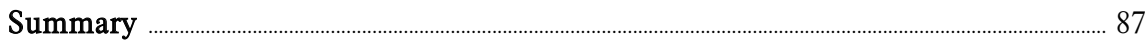




\section{Ajánlás}

A 2007-2012 időszakra vonatkozó, második Nemzeti Fejlesztési Terv részeként számos nagy jelentőségű tervezési folyamat zajlik, melyek részeként a Hálózat a Szabad Információért Alapítvány, a Duna-Körös Maros-Tisza Eurorégió Ifjúsági Szövetsége, az Európai Ifjúsági Kutató-, Szervezetfejlesztő és Kommunikációs Központ, valamint a Mobilitás Dél-alföldi Regionális Ifjúsági Szolgáltató Irodája kutatási konzorciumot hozott létre, és a régió ifjúsági szakembereinek együttmúködésével regionális ifjúsági helyzetelemző munkába fogott.

A kutatás egyik legfontosabb további célja, hogy a helyzetelemzés során feltárt problémák és lehetőségek rendszerezve jelenjenek meg a tervezési folyamatokban. Mindezzel tehát - tágabb értelemben - azt kívánjuk elérni, hogy ifjúsággal foglalkozó civil szervezetek, önkormányzatok, intézmények és szakemberek segítséget és forrásteremtési lehetőséget kapjanak a jövőben ahhoz a munkájukhoz, amely során a felnövekvő generációt képessé teszik, saját jövőjének felelős alakítására.

Az e kötetben publikált (kutatás közbeni) helyzetelemzés részben a releváns szakirodalmak, adatbázisok és statisztikák másodelemzésével, továbbá az Ifjúság 2000, illetve Ifjúság 2004 nagymintás ifjúságkutatás eredményeinek felhasználásával történt (melyért köszönettel tartozunk a Bauer Bélának, Gábor Kálmánnak, Kádár Péternek, Máder Miklósnak és Pilloch Péternek), míg a települési ifjúsági munkát és ifjúsági civil szcenáriót felmérő kérdőíves vizsgálat az EIKKA és a DARISZI munkatársainak segítségével folyik (szintén köszönjük Alattyányi István, Árvai Mara, Földvári Ágnes, Kökény Szabolcs, Sinkó Zsuzsanna, Szkalák István, Török László, Váry Éva és Vincze fózsef munkáját). A kutatási program lezárultakor eredményeinket zárókötetben jelentetjük meg.

Az volt a szándékunk, hogy a szociológiai elemzésen túl, már a kezdet kezdetén megfogalmazódjanak az ifjúsági szakma számára fontos problémák, alapelvek, és a szakemberek véleménye, elképzelései, ezért a helyzetelemzést kiegészítettük a régió mindhárom megyéjéből érkező mintegy 50 szakember (önkormányzati munkatársak, ifjúsági referensek, KEF képviselők, szabadidőszervezők, regionális tervezők, kutatók) részvételével elkészített régiós ifjúsági SWOT-elemzéssel, a megfogalmazott főbb problémákkal, és kitörési pontokkal. 
Hiszünk abban, hogy a kötet további közös gondolkodást hoz létre és gazdagítja az ifjúságról, illetve az ifjúsági szektorról való ismereteket, sőt hiszünk abban is, hogy javaslatokat, előterjesztéseket sarkall, valamint abban, hogy a Nemzeti Civil Alapprogram támogatásával zajló kutatás egységeként, majd a dél-alföldi régió ifjúsági civil szervezeteit felmérő kutatás további eredményeit is beépítve, a regionális tervezési folyamatok részévé válhat.

Kívánjuk, hogy forgassák haszonnal!

A Szerzók 


\section{Bevezetés helyett}

A regionális ifjúsági helyzetelemzés rámutat arra, hogy az ifjúságot érintő folyamatok hasonlóak az Európai Unióban e téren zajló társadalmi változásokhoz. Az öregedő társadalom, az elhúzódó tanulóidő, a tanuló fiatalok megnövekedett aránya, ezzel együtt az aktív, dolgozó fiatalok arányának csökkenése, a munkaerôpiac elvárásai, az ifjúság oktatás, munkaerôpiac és szabadidő tekintetében fennálló sebezhetősége, az intézményi rendszerbe vetett bizalom megrendülése, a határozott elfordulás az aktív, alakító közéleti részvételtől arra ösztönözte az Unió tagállamait, hogy újrafogalmazzák a fiatalokkal kapcsolatos kormányzati cselekvéseket az „Ifjúsági Fehér könyv”-ben.

Az elemzésekből kirajzolódó dél-alföldi jellemzők az ország többi régiójával összehasonlítva több területen is figyelmeztetően rosszabb helyzetben mutatják a régió ifjúságát.

A munka a régió ifjúsági helyzetét bemutatva rávilágít a tanuló fiatalok arányának növekedésére, amely tény kihatással van a többi vizsgált dimenzióra is. Ebből következik, hogy csökkent az aktív, dolgozó fiatalok aránya és növekedett a tanuló fiatalok aránya. Általánosságban elmondható, hogy a fiatalok helyzete rosszabbodott, mert anyagilag és a lakáshelyzet tekintetében rosszabb helyzetben vannak, mint négy évvel ezelőtt. Ezt tetézi még a növekvő munkanélküliség is. A lakáshelyzetben bekövetkezett változás mutatja, hogy a fiataloknak egyre nehezebb a lakáshoz jutás, azonban a tanuló fiatalok arányának növekedése is előidézhette a változásokat. Főleg a felsőfokú tanulmányok folytatásához sok esetben el kell költözni egy másik városba, ez magyarázhatja azt, hogy csökkent a lakással rendelkező és a szülőknél lakó fiatalok aránya is.

A fiatalok nem rendelkeznek több szabadidővel annak ellenére, hogy a tanuló fiatalok aránya növekedett. Ez azt mutatja, hogy olyan versenyhelyzet alakult ki az oktatásban, és a munkaerőpiacon, amely megköveteli, hogy a formalizált oktatási rendszeren kívül is képezzék magukat a fiatalok, ezt pedig a szabadidejükben teszik meg.

A szektort megcélzó pályázatokkal kapcsolatos tapasztalok alapján összességében elmondható, hogy kiemelt igény jelentkezik a programfinanszírozás, illetve a tárgyieszköz-fejlesztés, de ugyanakkor a programok közül a speciális, illetve táboros témakörökben. A legnagyobb igény e célokkal kapcsolatban mutatkozott, illetve valószínúleg fog is mutatkozni a gyermek és ifjúsági korosztállyal foglalkozó szervezetek részéról.

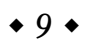


Elmondható, hogy általában a dél-alföldi régió civil bázisa nagyon erős és motivált, amit megerősítenek a Mobilitás és az NCA múködésének és pályázatainak információi és adatai is, természetesen a regionális különbségek itt is jellemzőek. Ugyanakkor a megoldást önmagában egy regionális cselekvésifejlesztési terv, az ifjúsági szcenárió szolgáltató rendszerének szorosabb, hálózat-szerû́ együttmúködése és komolyabb állami források hiányában nem hozhat. Ezen együttmúködésben az úgynevezett hazai és nemzetközi mintaprojektek által (és alapján) történő fejlesztés, de serkentés és lendületbe hozás időszerűsége megkérdőjelezhetetlen. A „felnőtt világnak” a fejlesztési tervek kidolgozásába komolyabban be kell vonni az ifjúsági szcenárió résztvevőit, tulajdonképpen magát az ifjúságot. (E tematikában nem szúkíthetők le a fejlesztés irányai a turizmus és a szabadidő szcenárióra.)

A regionális ifjúsági szolgáltató feladatokat ellátó iroda (DARISZI) jelenlegi infrastruktúrája nagy vonalakban kielégítőnek mondható, a kubatúra azonban felvet némi problémát, elsősorban a helyigény (helyiségigény) megoldása a sürgető feladat (képzőtér, megfelelően kialakított tájékoztató-ügyféltér nincs, s a jelenlegi irodai térszerkezet mellett azokat szinte lehetetlen létrehozni).

Az ifjúsági szolgáltató irodák (helyi és regionális) múködésének szakmai fejlesztési irányait meghatározhatják az úgynevezett Civil Szolgáltató Központokkal, a Teleházakkal és a települési önkormányzatokkal való fokozott kapcsolati rendszer kialakítása, így a helyi ifjúsági munka koordinációs szereplőjévé válás (katalizátor szerep). Mindehhez azonban az önkormányzatoknak (bizottsági, közgyúlési és polgármesteri szinten) és a politikai szereplőknek (egységesen) fokozott figyelmet kell fordítania a szervezett és a szervezeten kívüli ifjúságra egyaránt, a megfeleló és állandó források, tervezhetô és kiszámítható pályázati lehetőségek biztosítására és ugyanakkor a hiányzó közösségi terek megteremtésére, fejlesztésére.

Az önkormányzatok ifjúságpolitikai szervezeti felépítését vizsgálva megállapítható, hogy nagy különbség mutatkozik a településtípusok szerint. A nagyobb településeken sokkal jobban ki vannak építve az ifjúságpolitika szervezeti keretei. Megdöbbentő volt azonban azoknak a településeknek a magas aránya, akik nem is tervezik ifjúságpolitikai koncepció kialakítását. Az gyanítható, hogy az önkormányzatok a forráshiányos finanszírozás miatt nem tudnak energiát és pénzt fektetni az ifjúságpolitika szervezeti keretének kialakítására, ifjúsági koncepció kidolgozására. Ezt mutatja az a tény is, hogy azoknak az önkormányzatoknak a fele sem támogatja pénzzel az ifjúsági önkormányzatokat, amelyek múködési területén múködnek ilyenek. Általános- 
ságban elmondható, hogy az ifjúságpolitika szervezeti kereteinek, koncepcióinak kiépítettsége még nem érte el a nyugat-európai szintet.

A régió ifjúsági szakemberei az ifjúsági szakma problémáját két fő problémakörre osztották. Egyfelől hiányzik az önkormányzatok ifjúsági feladatellátásának szabályozását a jelenleginél határozottabban leíró rendelet, másfelől az ifjúsági szakma ismertsége és elismertsége nagyon alacsony, a szakma érdekérvényesítő képessége nem jelentős.

A helyzetelemzésben megfogalmazott kitörés pontok közül külön hangsúlyozzuk a fiatalok, fiatalokkal foglalkozók bevonását a helyi társadalomfejlesztési folyamatokba, az iskolarendszeren kívüli tanulás, a nemzetközi mobilitás serkentő környezetét megteremtő szervezetek, szakemberek támogatásának fontosságát.

Speciális területe a régiónak a szuburbanizálódó települések-, tanyasi, valamint a Duna alsó szakaszának fiataljai. A dél-alföldi régió legmarkánsabb kitörési pontjához csatlakozva az ifjúsági szakma számára is fontos a DunaKörös-Maros-Tisza Eurorégiós együttmúködések katalizálása. 


\section{A dél-alföldi régióban élő fiatalok ${ }^{1}$ helyzete}

\subsection{Népességszám}

Bár a dél-alföldi régióban az elmúlt tíz évben csökkent a népességszám, még így is az ország harmadik legnépesebb régiója. 2001. február 1-én 1.377.177 fó lakott a térségben. Ebből 232.675 fó a 0-14 éves gyermek és 292.088 fó a 15-29 éves fiatal; összesen 524.763 fó.

2005-re a régió népessége 1.354 .938 főre csökkent, a fiatalok száma (0-29 év) pedig 496.118-ra. A négy év természetes fogyása 22.239 fó, a fiatalok korcsoportjában ez a szám még megdöbbentőbb: 28.645 fó.

Az 1. számú ${ }^{2}$ grafikonból látható, hogy fogy a népesség, egyre kevesebben vannak a fiatalabb korosztályokban. A népességfogyásból adódóan a régió korfájának az összetétele egyre kedvezőtlenebb képet mutat. (2. grafikon)

\section{A dél-alföldi régióban élő fiatalok korcsoport szerint (fó)}

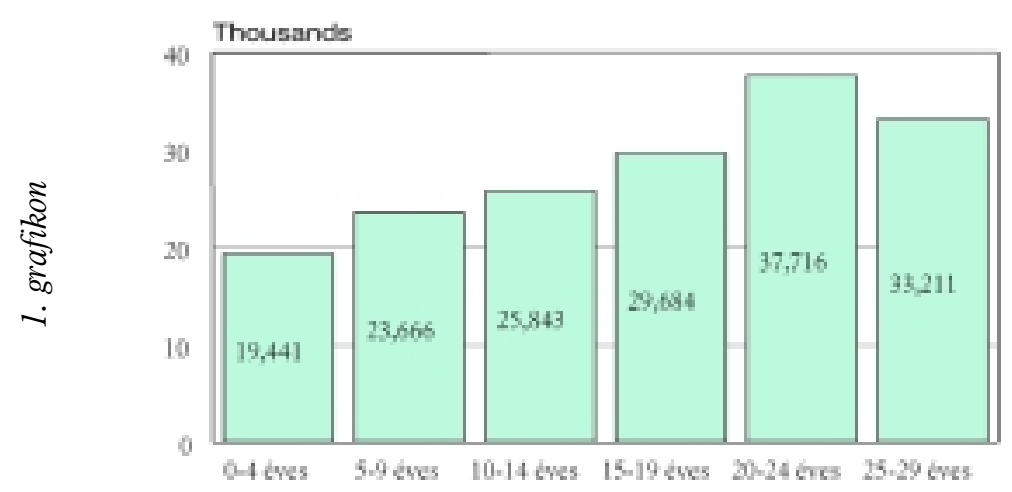

\footnotetext{
${ }^{1}$ 1995. évi LXIV. törvény a Gyermek és Ifjúsági Alapról, a Nemzeti Gyermek és Ifjúsági Közalapítványról, valamint az ifjúsággal összefüggő egyes állami feladatok ellátásának szervezeti rendjéról szóló törvény 8. \szerint „gyermek: a 0-14 éves korosztályokhoz tartozó személy; fiatal: a 15-26 éves korosztályokhoz tartozó személy.” Az Európai Unióban országonként más és más a fiatalokhoz köthető korosztályi besorolás. Erről bővebben Bodor András-Gabreille Lara: az ifjúságpolitikák jogi és szervezeti keretei: az európai gyakorlat áttekintése in: Új ifjúsági szemle 8. (III. évf. 3.szám 5-33)

${ }^{2}$ A 2001-es népszámlálás adatai (KSH)
} 


\section{A természetes fogyás régiónként (ezrelékben)}

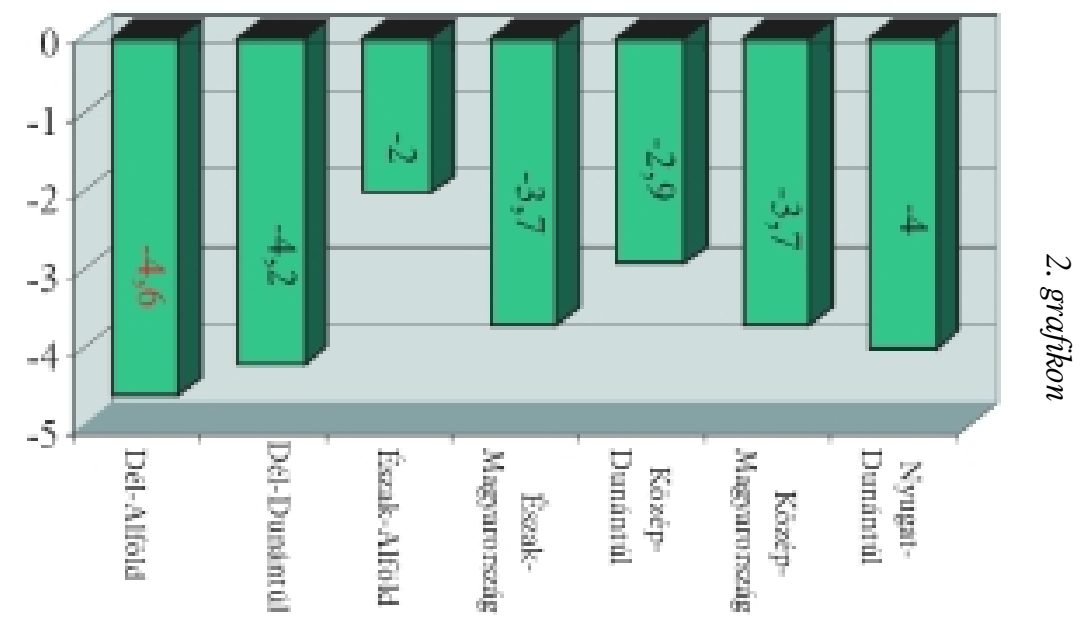

A korfa is mutatja (14. oldal), hogy egyre öregedik a régió lakossága, amely a későbbikben fokozott gazdasági terhet fog róni a most fiatal korosztályra. A mai kirovó-felosztó szociálpolitikai rendszer stabilitása is veszélybe kerülhet, mert sokkal kevesebb aktív ember lesz, mint eltartott.

1990-ben a régió lakosságának 20\%-a volt 15 év alatt, ez 2004-re visszaesett 16\%-ra. Mindeközben a 64 éven felüliek aránya 14\%-ról 16\%-ra növekedett.

A 0-29 éves korosztály körében elmondható, hogy több fiú van, mint nő. A legnagyobb eltérés a nemek tekintetében a 10-14 éves korosztálynál található 945 lány jut ezer fiúra. A legkisebb eltérés pedig a 20-24 éves korosztálynál található itt 984 lány jut ezer fiúra.

\subsection{Családi állapot}

A dél-alföldi fiatalok nagy része nőtlen/hajadon (88,4\%), csak 10,4 százalékuk házas. A 20-24 éves korosztálynál is magas a nőtlenek/hajadonok aránya (88,5\%) és alacsony a házasságban élőké. (10,6\%) A 25-29 éves korosztályt vizsgálva megállapítható, hogy több mint a felük (54.2\%) még nem kötött házasságot, házastársi viszonyban él 40,7\% és már elvált a korosztály 3 százaléka. 


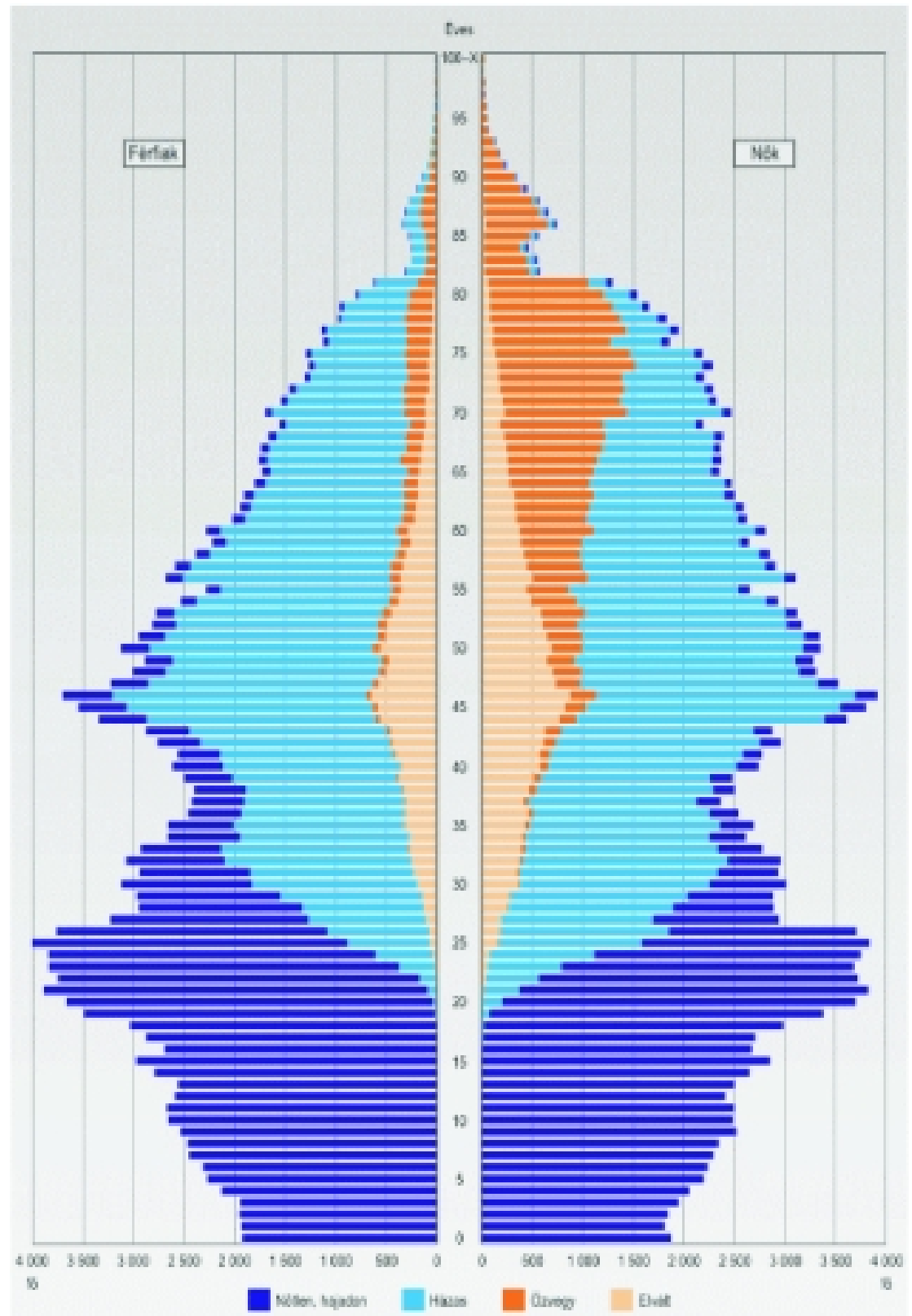

$-14$ 


\subsection{Iskolázottság}

A dél-alföldi fiatalok 31\%-a végzete el az általános iskola 8 osztályát, 23,4\% szakmunkásképzőt végzett 36,1\% érettségivel rendelkezik és a régióban élő fiataloknak 9,4\%-a diplomával rendelkezik. ${ }^{3}$ A 14 évnél idősebb fiataloknak 97,8\%-a végezte el az általános iskolát. A 19 éves vagy idősebb fiatalok 61,1 \%a szerzett érettségit, és a 24 évesnél idősebb fiatalok $23,2 \%$-a végzett felsőfokú iskolát. ${ }^{4}$ (3. grafikon)

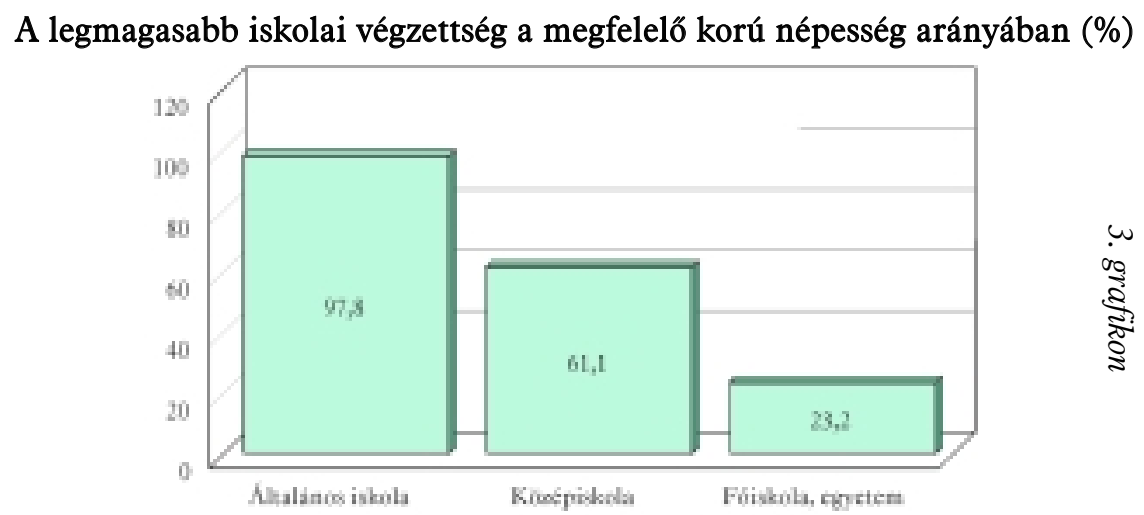

Ezek az arányok a jövőben várhatóan emelkedni fognak, mert a megkérdezetteknek a $65,8 \%$-a mondta azt, hogy még szeretne tovább tanulni. A megkérdezettek 48,6\%-a szeretne felsőfokú iskolában továbbtanulni és a 28,5\%-a szeretne érettségit szerezni.

Az iskolázottság tekintetében nincs nagy eltérés az országos átlaghoz képest. A régióban kicsivel magasabb a szakmunkásképzőt végzettek aránya (országos átlag 21,6\%) és kicsivel alacsonyabb az egyetemet/föiskolát végzettek aránya (országos átlag 10,1\%).

Az Ifjúság 2000 adataival összehasonlítva látható, hogy csökkent az általános iskolát végzettek (32\%) és a szakmunkásképzőt végzettek (27,5\%) aránya, viszont nőtt az érettségivel rendelkezők (33\%) és a felsőfokú képesítéssel rendelkezők (6,5\%) aránya. Ez azt mutatja, hogy átlagosan növekedett a régióban élő fiatalok iskolázottsága. (4. grafikon)

\footnotetext{
${ }^{3}$ Ifjúság 2004 kutatás adatai

${ }^{4}$ A 2001-es népszámlálás adatai
} 


\section{A dél-alföldi régió fiataljainak iskolázottsága (\%)}

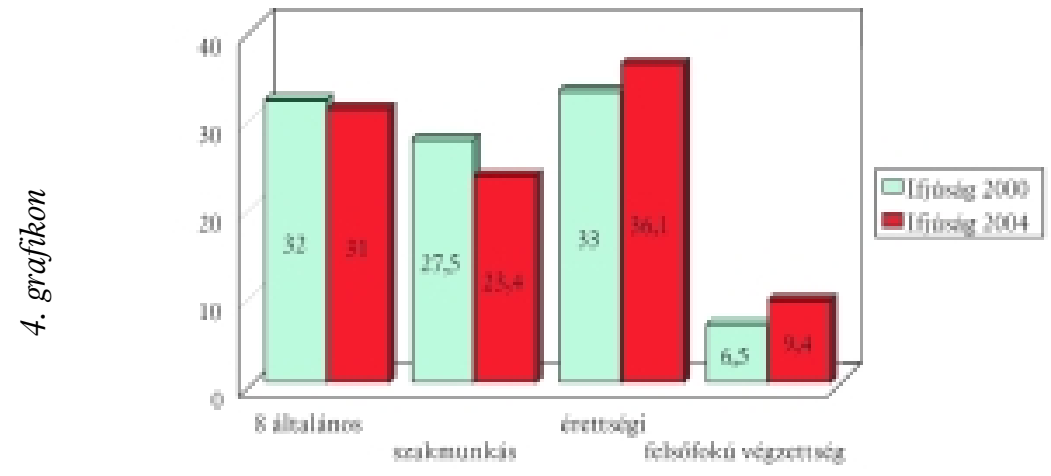

\subsection{Gazdasági aktivitás}

A régióban élő fiataloknak a 38,6 százaléka dolgozik, 38,9 százalékuk pedig még tanul. A munkanélküliség jelenleg 8 százalékos. De elmondható, hogy a régió fiataljai közül 31,2 százalék már volt munkanélküli. Az országos összehasonlítás szerint elmondható, hogy valamivel kevesebben dolgoznak (országos átlag 39\%), de valamivel többen tanulnak (országos átlag 37,9\%). Azonban a munkanélküliség magasabb a régióban, mert országos átlagban a 7,3\% a munkanélküliek aránya, és országosan kevesebben voltak valaha munkanélküliek. (28,4\%) 2000-hez képest 12 százalékponttal csökkent az aktív, dolgozó fiatalok aránya. (5. grafikon)

Gazdasági aktivitás (\%)

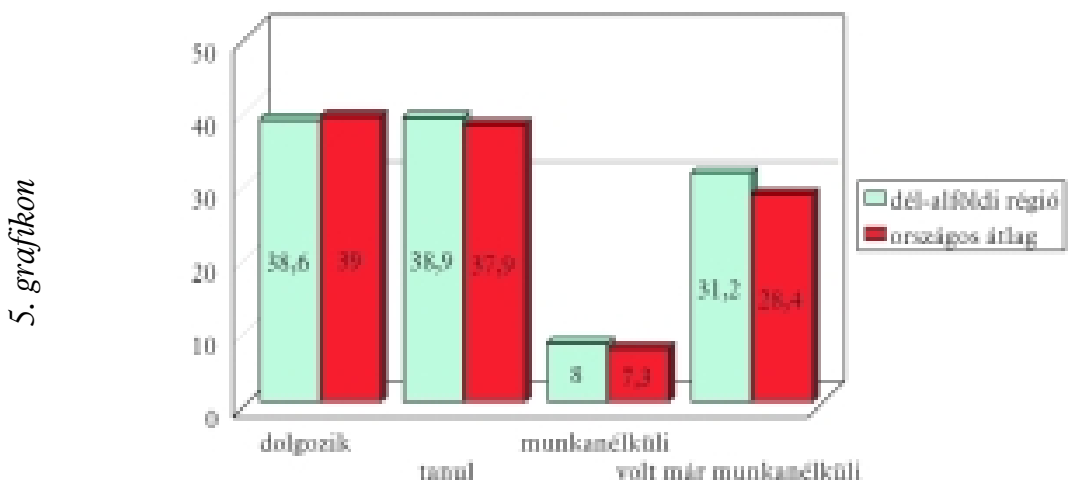


Míg 2000-ben a fiatalok 46,8\%-a dolgozott, addig 2004-ben csak a 38,6\%uk. Azonban nőtt a tanuló fiatalok aránya 33,5\%-ról 38,9-ra. De csak ezzel nem lehet magyarázni, az aktív népesség arányainak csökkenését. A munkanélküliség is növekedett az elmúlt négy évben 7,4\%-ról 8\%-ra. (6. grafikon)

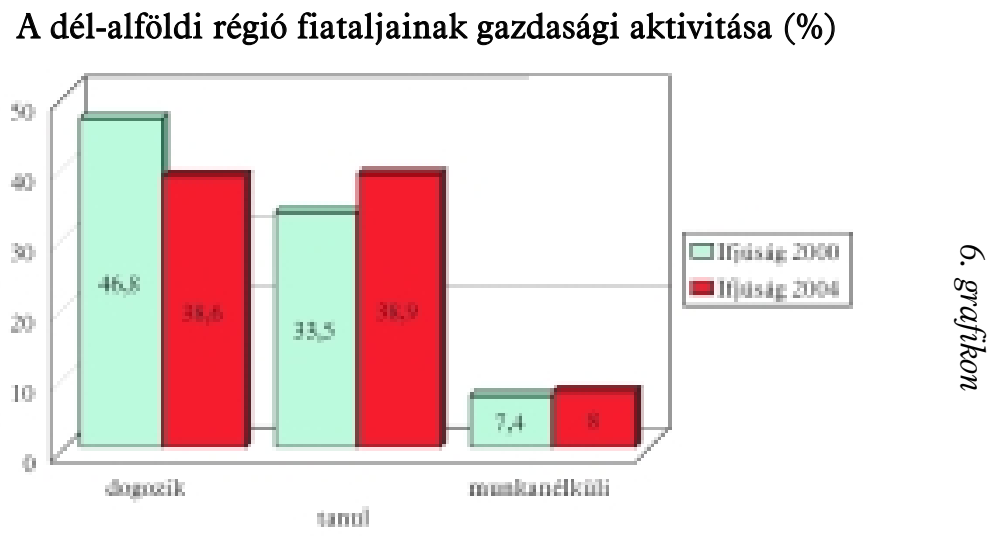

A munkavállalásról általában a következőket mondhatjuk el. Fokozódik a verseny a minőségi munkahelyekért a már diplomával rendelkező fiatalok és a mindenkori végzősök között, mindeközben a kevésbé képzettek, kevesebb bizonyítvánnyal, vagy kevésbé „tekintélyes” papírral rendelkezők nehézségei megsokasodnak, melynek következtében a munkavállalás során kialakul egyfajta bizonytalanság és esetlegesség: az iskolából a munkába átmenetet káosz jellemzi. Sok esetben egy bizonyos ideig tartó munkanélküliség mára normális része az iskolából a munkába való átmenetnek még azok számára is, akik komoly szakmai képesítéssel rendelkeznek. Az önfoglalkoztatás jelentősége éppen ezért növekszik, annak ellenére, hogy itt az üzleti kudarcok mértéke azonban magas, a nyereség pedig alacsony. A fiatalok élete ekkor a próbálkozások, kudarcok és újrakezdések sorával írható le. Az önfoglalkoztatást ugyanakkor egyfajta túlélési stratégiának, nem pedig valamiféle pozitív választási lehetőségnek fogják fel.

Az általános ismeretek, állampolgári ismeretek, kulturális ,ismeretek” többsége háttérbe szorul az úgynevezett szakismeretekkel (skill) szemben. „A munkanélküliség szcenáriója azzal jár, hogy potenciálisan már nagyon korán kialakul azon fiatalok csoportja, akik nagyon kis eséllyel integrálódhatnak a társadalomba, létrejön a társadalom alatti osztály reprodukciója. A ro- 
ma fiatalok iskolázottsága rendkívül alacsony, mely összekapcsolódik regionális egyenlőtlenségekkel. A globalizáció következményeként növekszik a nemzetközi munkaerőpiac kihívása, mely különösen az alacsony iskolázottsággal rendelkező csoportokat érinti. A munkanélküliségi forgatókönyvet mélyíti az alacsony iskolázottsággal rendelkezők, illetve az alacsony jövedelmú réteg újratermelődése, a szegénység reprodukciója.” (Ifjúságpolitikák, 37)

Mindezek mellett azt mondhatjuk, hogy a munkaerőpiacon különösen sérülékenyek: az oktatási rendszerből az alsóbb középiskolai szint körül kikerülők, az alapvetô írás-olvasási és számtani készség nélküliek, az átképző-továbbképző programokon részt vevő szakmunkástanulók, a nyugati munkaadók által elvárt tudással (pl. nyelvtudás, informatikai ismeretek) nem rendelkezők, a fiatalkorú bűnözők, az otthontalanok, a fogyatékkal élők, az egyedülálló anyák, az állami gondozásban fölnőttek, és a roma fiatalok.

\subsection{Anyagi helyzet}

Az országos adatokkal összehasonlítva kiderül, hogy a régióban élő fiatalok rosszabb anyagi körülmények között élnek, mint az ország más területein éló fiatalok. A megkérdezett fiatalok 23,2 százaléka említette, hogy havonta elfogy a család pénze. Ez az arány országosan csak 20,4 százalék volt. A fiatalok 43,8 százaléka mondta azt, hogy soha nem fordul elő, hogy a hónap vége előtt elfogyna a pénzük, ezzel szemben az országos átlag ennél kevesebb 41,3 százalék. A régióbeli fiatalok családjai közül 15,3\% tud havonta félrerakni pénzt, ez országosan csak kicsivel magasabb 16 százalék. (7. grafikon)

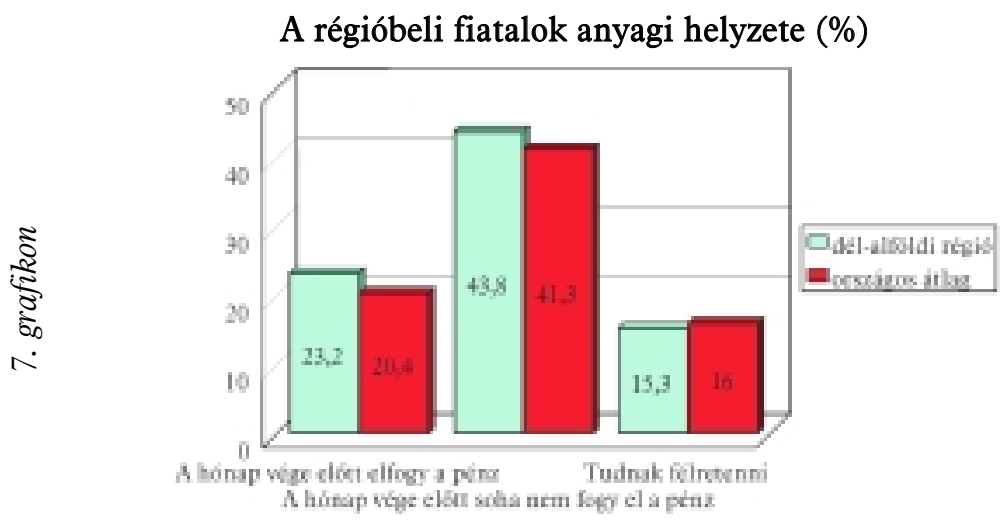


$\mathrm{Az}$ anyagi helyzet mérésére a kutatásban rákérdeztek arra is, hogy milyen értékes fogyasztási cikkekkel rendelkeznek a fiatalok. A régióban a legtöbben CD-lejátszóval rendelkeznek (41\%), ezt követi a saját videomagnó (38\%) és a saját hifi torony (37,2\%). Az országos átlag a hifitornyok tekintetében 40,7\%. A tartós fogyasztási cikkekkel való rendelkezés aránya a régióban alacsonyabb, mint az országos átlag. Személygépkocsival a régióban élő fiatalok 27,5 százaléka rendelkezik, míg itt az országos átlag $28,5 \%$.

2000-hez képest romlott a régió fiataljainak az anyagi helyzete. 2000-ben csak a háztartásoknak a 17,8\%-ból fogyott el a hónap vége elótt a pénz, addig 2004-ben ez már 23,2\% volt. Csökkent azoknak az aránya is, akiknél soha sem fogyott el a pénz a hónap vége előtt. 2000-ben a fiatalok családjainak a 47,6\%a minden hónapban kijött a pénzéből, 2004-ben pedig már csak a 41,3\%-uk. Azonban meg kell jegyezni azt is, hogy 2000-hez képest 6 százalékponttal nôtt azon családok aránya, ahol havi rendszerességgel tudnak pénzt félretenni. (2000-ben 10\%, 2004-ben 16\%). Ez azt valószínűsíti, hogy kialakult egy szúk anyagi értelemben elitréteg, azonban a távolság az elitréteg és a többség között növekedett.

\subsection{Lakáshelyzet, mobilitás}

A dél-alföldi fiatalok lakáshelyzetéről elmondható, hogy hasonló képet mutat, mint az országos átlag. A fiataloknak a 63 százaléka lakik a szüleinél és mindösszesen 10 százalék lakik saját lakásban. Összességében a fiatalok 83,3\%-a meg van elégedve a jelenlegi lakásviszonyaival, amely magasabb, mint az országos átlag. (80,1\%). Ennek ellenére mégis $42 \%$ tervezi, hogy változtat majd a jelenlegi lakásviszonyán. A régió fiataljai átlagosan 3,7 fős háztartásokban élnek.

A fiataloknak több mint az egyharmada tervezi azt, hogy elköltözik abból a településből, ahol jelenleg él (36,1\%)

2000-hez képest $(66,6 \%)$ csökkent azoknak a fiataloknak az aránya, akik otthon laknak a szülóknél. Ez egyrészről azért is meglepő, mert azoknak a fiataloknak az aránya is csökkent, akik saját lakásban élnek. (2000-ben 18,8\%, 2004-ben 10\%). Ennek egyik magyarázata, hogy a saját lakáshoz jutás nehezebbé vált. De egy lehetséges ok lehet, hogy a felsőoktatásban tanuló fiatalok aránya növekedett, akik ezáltal a nagyobb városokban kollégiumba, vagy albérletbe költöztek. 


\section{7 Életmód, szabadidő}

A fiataloknak csak egy kicsi hányada nem rendelkezik szabadidővel egy átlagos hétköznap (5,1\%). Azoknak az aránya is alacsony, akik csak napi 1 óra szabadidővel rendelkeznek. (12,3\%). A fiatalok legnagyobb (45,5\%) része napi 1-3 óra szabadidővel rendelkezik. Ezek az arányok teljesen megfelelnek az országos átlagnak. A régióban élő fiatalok negyedének legalább az egyik hétvégi napja szabad és további 24,8\%-nak mindkét hétvégi napja szabad. Ez az arány is megfelel az országos átlagnak. A szabadidő nagy részét a fiatalok az otthonukban töltik el, mivel a megkérdezettek 90,4 százaléka jelölte be ezt a válaszlehetőséget. Ez mutatja azt, hogy a szabadidót passzívan töltik a fiatalok. A második helyen a „barátokkal találkozás” áll, de sokkal kevesebben jelölték be ezt a válaszlehetőséget. (27,9\%). A harmadik leggyakoribb szabadidős tevékenység a rokonlátogatás. (15,7\%). A szabadidő eltöltésének módjában nagyobb eltérést találunk az országos átlaghoz képest. Országos szinten is az otthon eltöltött szabadidő jelenti a leggyakoribb kikapcsolódást, de ez országosan valamivel alacsonyabb: 87 százalékot jelent. A barátokkal 26,3 \% találkozik országosan, de a harmadik leggyakoribb szabadidős tevékenység a rokonlátogatás helyett a partnerrel való találkozás, amely a fiatalok $13,2 \%$-át érinti.

A fiatalokról általában gyakran azt gondolják, hogy bőségesen rendelkeznek szabadidôvel, ugyanakkor azt kell mondjuk, hogy annak mértéke valójában folyamatosan csökken, mivel a fiatalok egyrészt az ,iskolai tudás” kiegészítését is a szabadidő rovására teszik (különórák, nyelvtanulás), másrészt - fóként az oktatási életszakasz későbbi részében - részmunkaidőben munkát is végeznek.

A fiatalok szabadidejüket gyakran és szívesen töltik olyan készségek fejlesztésével, amelyeket életük sikerességéhez fontosnak tartanak (ezek nagy része olyan készség, amelyek alapja a kötetlen csoportos oktatás). Mindez arra enged következtetni, hogy fokozott igény áll elő az úgynevezett iskolán kívüli oktatási-nevelési intézmények és a nem formális neveléssel kapcsolatban.

A fiatalok mai generációi egy sajátos társadalmi környezetben szocializálódnak, ahol a legfontosabb tájékozódási pont a média által „megcsinált” sztárok, a diszkók és a presztízsfogyasztásra épülő áruvilág által alkotott, és folyamatosan múködtetett, fejlesztett, behatárolt tér. Az úgynevezett piaci szabadidő-eltöltési forma mintái egyre inkább elterjednek, azonban ebból - mivel számos fiatal rekesztődik ki a pénzforrások hiánya miatt - új és új sebezhetôségek nőnek ki. Azok számára, akik a fentebb leírtak miatt nem tudnak bekapcsolódni a piaci 
alapú elfoglaltságokba, egyre kevesebb lehetőség adódik a szabadidő hasznos eltöltésére, hiszen a mindenkori pénzügyi megszorítások az ifjúsági intézmények ingyenes szabadidős szolgáltatásait folyamatosan gyengítik és csökkentik.

A tendenciák szisztematikusan így írhatók le: „A bekövetkező változások alapja az, hogy a szórakoztatóipar képviselői hisznek abban, hogy a felhasználóik természete változik, úgy látják őket, mint akik rendelkeznek olyan tulajdonságokkal, amelyek korában egyértelműen a középosztály tagjait jellemezték, mint például a tehetősség, a mobilitás és a képesség arra, hogy a számukra felkínált szórakozási lehetőségek között »racionális« alapon tudnak választani. Ez a változás jelenik meg abban, hogy a hangsúly a »szórakoztatóiparban« tapasztalható »versenyen « van, de megragadható abban is, hogy a vásárlót már nem a »tagnak«, hanem a »fogyasztónak« tekintik"

Elmondhatjuk, hogy mivel a szabadidő kihasználásának megtanulása és gyakorlása a személyes elégedettség központi kérdése, azok a fiatalok, akiknek a fentiek szerint nem jut ki változatos szabadidős életstílus, később felnőttként sem tudják kielégítóen eltölteni szabadidejüket, s feltételezhetôen nehezen fognak megbirkózni egy esetleges gazdasági inaktivitás nehézségeivel, majd a peremléten tengődő outsiderekké válnak. S míg a napos oldalon mozgó insider saját előrehaladását egyenes ívűnek, önmagát pedig a siker példájának tartja, a „kívülállót” az örökké árnyékos oldal rabjává teszi a számára elérhető és elérhetetlen társadalmi kapcsolatok hálózata. ${ }^{6}$

\section{8 Értékrend, jövőkép}

A jövóképet tekintve megállapítható, hogy a fiatalok nagyobb része optimista, mint pesszimista. Külön kiemelendő az a tény, hogy a saját helyzetüket jóval optimistábban ítélik meg, mint az ország gazdasági helyzetét, vagy az emberek életszínvonalának változását. Ez arra utalhat, hogy bíznak saját magukban, bíznak abban, hogy az ország gazdasági helyzetének változásától függetlenül előre tudnak lépni. A saját jövőbe vetett hitet támasztja alá az a tény is, hogy a fiatalok nagyon nagy részének $(93,1 \%)$ vannak konkrét elképzelései, tervei a jövőre nézve, amiket 5 éven belül meg szeretnének valósítani. A személyes ter-

${ }^{5}$ Clarke, J. - Jefferson, T:: A munkásosztály ifjúsági kultúrái. In. Gábor Kálmán: A középosztály szigete. 2001, 115-117

${ }^{6}$ Tamás Pál: Gyökerek és szárnyak. Avagy a szolidaritás átrendezódése. In. Ifjúságpolitikák, 2005 
vek tekintetében a dél-alföldi régióban éló fiatalok ambiciózusabbak, mint az országos átlag. (89,3\%) (8. grafikon)

\section{A dél-alföldi fiatalok jövőképe (\%)}

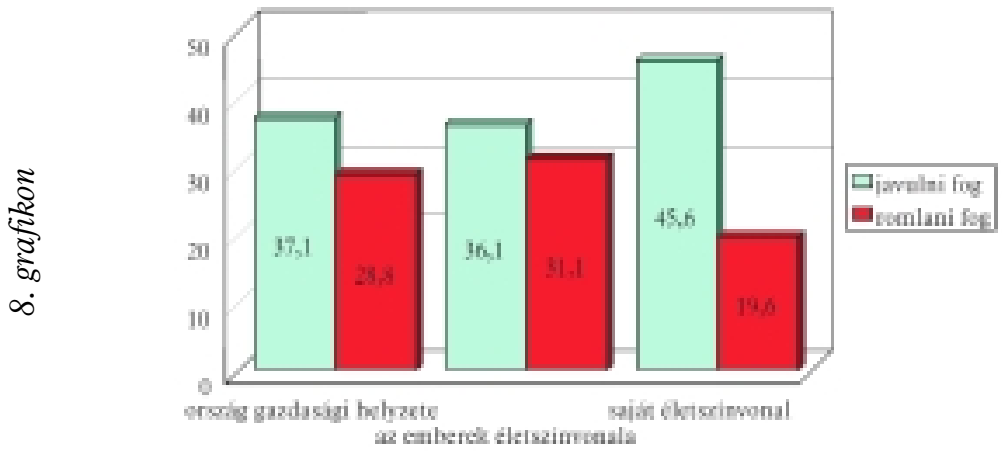

2000-hez képest bizakodóbbá váltak a fiatalok, mind az ország gazdasági helyzetét (2000-ben optimista 32,8\% pesszimista 30,9\%, 2004-ben optimista $37,1 \%$, pesszimista $28,8 \%$ ), az emberek életszínvonalát (2000-ben optimista $29,5 \%$ pesszimista $37,2 \%$ 2004-ben optimista $36,1 \%$ pesszimista $31,1 \%$ ) és a saját jövőjüket tekintve. (2000-ben optimista 29,8\% pesszimista 21,8\% 2004ben optimista 45,6\% pesszimista 19,6\%) (9. grafikon)

\section{A dél-alföldi régió fiataljainak jövőképe (\%)}

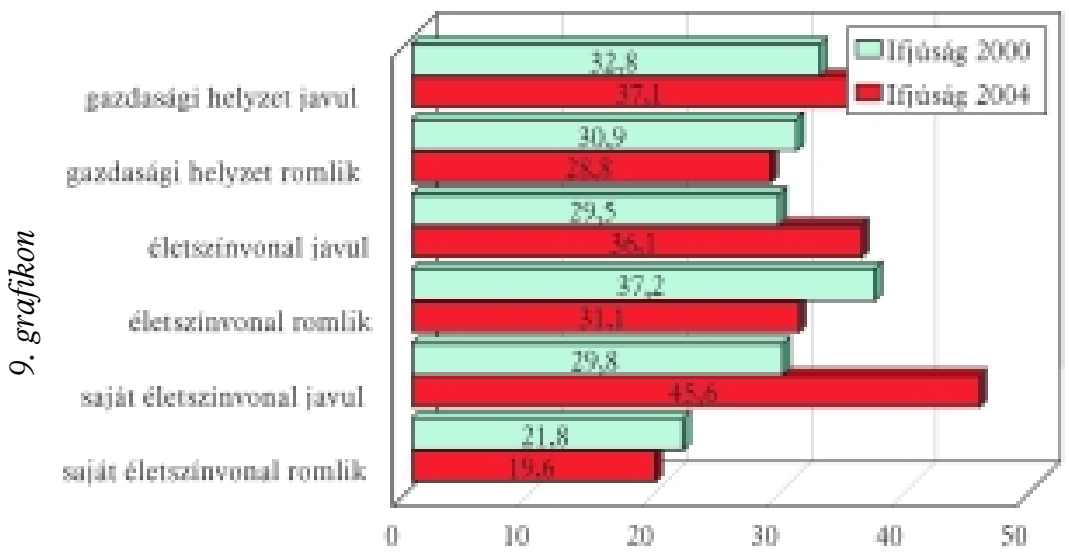


Az értékeket vizsgálva megállapítható, hogy a családi biztonságot tartják legfontosabbnak a fiatalok (86,6\%), ezt követi a szerelem (82\%), a harmadik legfontosabb érték az igaz barátság (79,5\%). Ezeken az értékeken kívül nagyon fontos még a békés világ (77\%) és a belső harmónia is. (72,8\%) A legkevésbé fontos értéknek a hatalmat tartották (7,2\%), amelyet a vallásos hit követet (14\%). Az országos átlaggal összehasonlítva megállapítható, hogy valamivel magasabb azoknak az aránya a dél-alföldi régióban, akik a családot tartják a legfontosabbnak. (országos átlag 84,9\%)

\subsection{Devianciák}

A dél-alföldi régióban élő fiataloknak kicsivel több, mint az egyötöde egyáltalán nem fogyasztott alkoholt az elmúlt egy évben, 34,8 százalékuk pedig ritkábban, mint havonta. Országos szinten a teljesen absztinens fiatalok aránya magasabb (24,2\%). A dél-alföldi fiataloknál egy kicsivel magasabb az alkoholfogyasztás, mint az országos átlag, míg a dél-alföldi fiatalok 1,7\%majdnem minden nap iszik alkoholt, addig az országos arány csak 1,5\%. Azonban az alkoholfogyasztás mennyiségében már jelentős eltérést tapasztalható, míg a dél-alföldi fiatalok 39,1 százaléka nyilatkozott úgy, hogy előfordult, hogy többet ivott a kelleténél, addig az országos átlag csak 25,1\%. (10. grafikon)

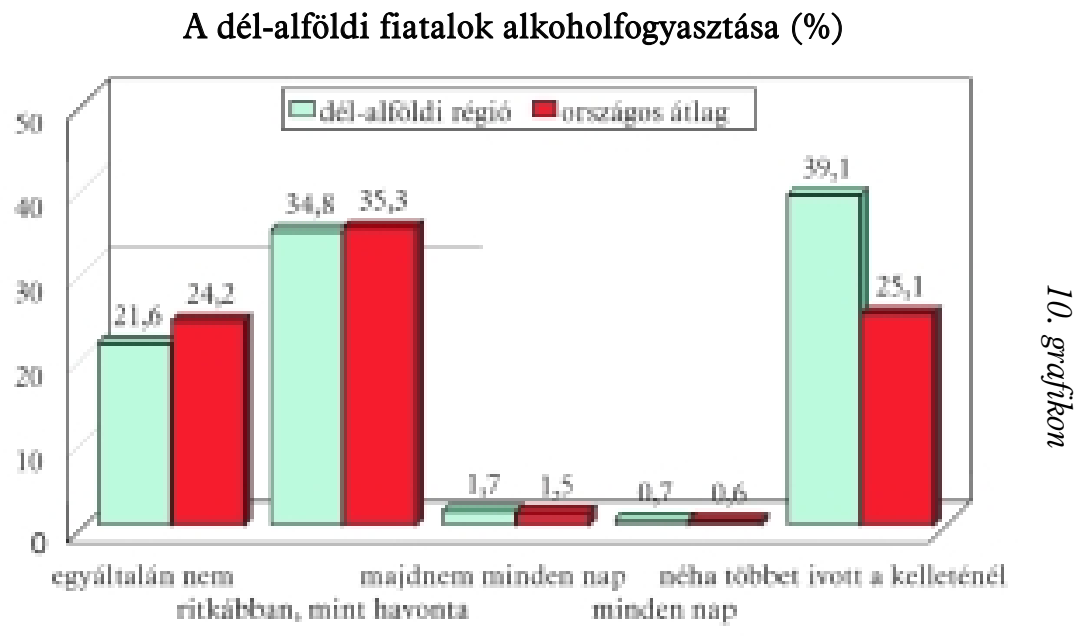


A drogfogyasztás tekintetében valamivel magasabb a drogot valaha is használtak aránya (44,2\%) a dél-alföldi régióban, mint az országban. (42,7\%)

A dél-alföldi fiatalok 62 százaléka egyáltalán nem dohányzik 18,2\% fél dobozzal szív el egy nap, 17,1\% egy dobozzal szív el egy nap és 2,7\% több mint egy dobozzal szív el egy nap. Ezek az arányok nagyon hasonlítanak az országos átlaghoz.

\section{Civil szervezetek, közélet}

A dél-alföldi régióban alacsony azoknak a fiataloknak az aránya, akik tagjai valamilyen civil szervezetnek vagy politikai pártnak. (15,2\%) Ez az arány pontosan megfelel az országos átlagnak is.

A kutatás során vizsgálták azt is, hogy a fiatalok mennyire bíznak meg a különböző állami intézményekben. Az első helyen a bíróság végzett: a fiataloknak a 20,6\%-a bízik meg teljesen a bíróságokban. A második helyen a rendőrség áll a fiatalok 17,7\%-a bízik a rendőrökben.

A legkevésbé a kormánypártokban bíznak a fiatalok, csupán 4\% azoknak az aránya, akik teljesen megbíznak bennük. Az ellenzéki pártokban is csak a fiataloknak a 6,3\%-a bízik meg. Az egyházakban közepesen bíznak meg a délalföldi fiatalok $16,8 \%$, teljesen megbízik bennük, viszont nagyobb azoknak az aránya, akik egyáltalán nem bíznak meg bennük. (33\%) A közszolgálati média bizalmi szintje is nagyon alacsony, mert csupán a fiataloknak valamivel több, mint az egytizede bízik meg benne, ennek az aránynak a duplája azoknak az aránya, akik egyáltalán nem bíznak meg benne.

\subsection{Információs társadalom}

A dél-alföldi fiataloknak több mint a fele $(52,8 \%)$ rendelkezik számítógéppel. Kicsivel több, mint egyharmaduk (37\%) Internettel is rendelkezik. Ezek az arányok országos átlag alatt maradnak. (számítógép 57\%, Internet 43\%). (11. grafikon)

A fiatalok számítógép, illetve Intenet-használatát vizsgáljuk, abból indulunk ki, hogy egyfajta digitális szakadék áll fenn a fiatalok és a felnőttek között. A fogalmat Margarett Mead 1978-ban Culture and Commitment (The New Relationship between the Generations in the 1970's) címú munkájában 
Dél-alföldi fiatalok és az információs társadalom (\%)

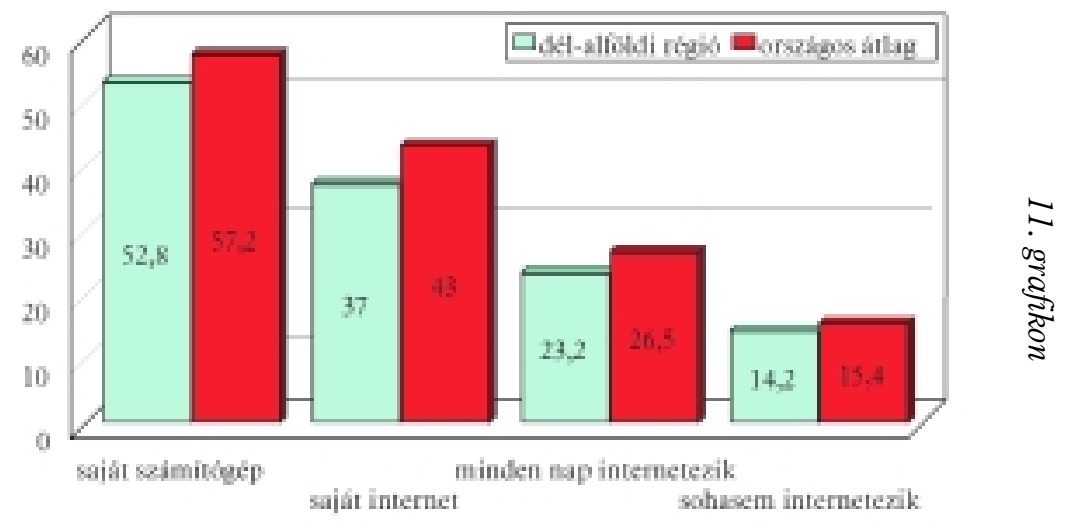

fejtette ki először, megállapította, hogy a fiatalok a technikai eszközök időbeli fejlődésével az informatikai és a kommunikációs eszközöket természetes módon alkalmazzák.

A fiatalok számítógép- és Internet használatának értelmezésekor azonban mindig figyelembe kell venni azt is, hogy a fentebb leírt szakadék része egy nagyobb, a magyar társadalmat jellemző digitális egyenlőtlenségi rendszernek ${ }^{7}$, mindezért tehát a dél-alföldi fiatalok helyzetét vizsgálva szükséges, volna egyfajta, a fogyasztói státusz mintájára kialakított úgynevezett kommunikációs státusz kategória kialakítása. Ennek összetevői pedig a számítógéppel való rendelkezés, otthoni Internet-hozzáféréssel való rendelkezés, más Internet hozzáférés (általánosan: otthon, iskolában, munkahelyet, stb), de itt vizsgálhatjuk a saját, illetve családi mobilhasználatot (sms, wap, gprs, $\mathrm{mms}$ ). A Dél-alföldi régióban további munkát igényelnek a fiatalok kommunikációs státuszára vonatkozó kutatások. E helyütt az alapadatok bemutatására volt lehetőségünk.

A megkérdezetteknek a legnagyobb része leggyakrabban az iskolában internetezik (34,6\%), második helyen az otthoni internetezés áll (25,3\%) és ennél sokkal alacsonyabb azoknak az aránya, akik a munkahelyükön vagy Internetkávézókban neteznek (10-11\%).

2000-hez képest nagy előrelépés mutatkozik az Internet-használat és a számítógép-használat tekintetében is. 2000-ben a fiataloknak csak 20\%-a rendel-

${ }^{7}$ Gábor - Matiscsák - Kabai: Információs társadalom és az ifjúság. 2003, 54 
kezett számítógéppel, addig ez az arány 2004-ben már 52,8\%. Az otthoni Internettel rendelkezők aránya még nagyobb mértékben növekedett, amíg 2000-ben csak a háztartások 5,8\%-ában volt Internet hozzáférés, addig 2004ben már a háztartások 37\%-ában. (12. grafikon)

\section{A dél-alföldi fiatalok Internet és számítógép-ellátottsága (\%)}

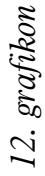

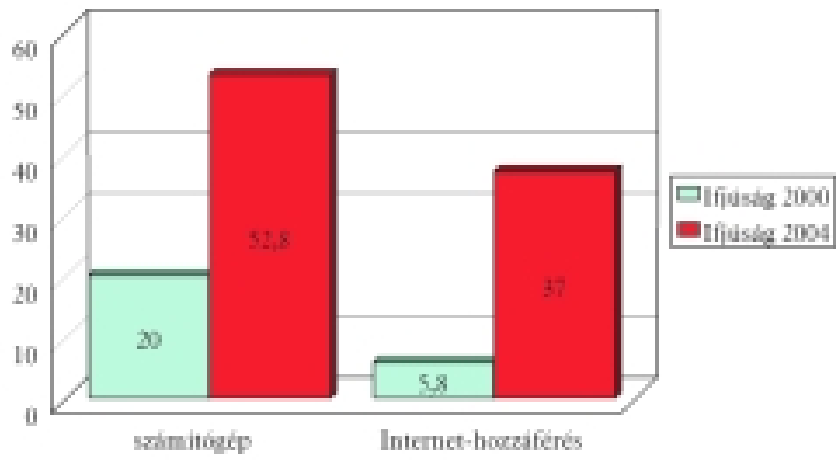




\section{Ifjúságpolitikai helyzetkép \\ 1 Intézményrendszer, szolgáltatások (régió-megye-település)}

\subsection{RISZI tevékenységei, szolgáltatásai, fejlesztési lehetőségei}

A regionális ifjúsági irodák országos hálózatát a 2/1999 (IX. 24). Ifjúsági és Sportminisztériumi (ISM) rendelet hozta létre. A Gyermek és Ifjúsági Alapprogram (GYIA) és a regionális ifjúsági irodák múködéséről rendelkező rendelet határozza meg a Dél-alföldi Regionális Ifjúsági Szolgáltató Iroda (DARISZI) fó feladatait. ${ }^{8}$

A DARISZI alakulásakor Kecskemét székhellyel kezdete meg a múködését, majd 2003 végén költözött Szegedre. E tényező befolyással bírhat a regionális színtű múködésre, hiszen Szegeden újra kellett szervezniük-indítaniuk a munkát, ám a székhelycsere a szolgáltatói célközönség számára néhány technikai probléma (telefonos elérhetőség, e-mailek) esetében és kizárólag az első egy-két hónapban jelentkezett. Mindez - azt gondoljuk - a munkatársak, illetve a székhelycserét koordinálók munkáját dicséri. Az iroda jelenlegi infrastruktúrája kielégítőnek mondható, a kubatúra azonban felvet némi problémát, elsősorban a helyigény (helyiségigény) megoldása a sürgető feladat (képzőtér, megfelelően kialakított tájékoztató-ügyféltér nincs, s a jelenlegi irodai térszerkezet mellett azokat szinte lehetetlen kialakítani).

A DARISZI, fennállása óta - a rendeletben megfogalmazottak mellett - folyamatos tanácsadást nyújt az önkormányzati ifjúsági programok, helyi és tér-

\footnotetext{
${ }^{8}$ A DARISZI feladatai: a) kezdeményezi regionális fejlesztési programok, alprogramok indítását, közremúködik tervezésükben és megvalósításukban, $b$ ) közremúködik a Gyermek és Ifjúsági Alapprogramból támogatott, illetve felkérés alapján más projektek értékelésében, szakmai és pénzügyi ellenőrzésében, c) segíti az Európai Unió, az Európa Tanács és más nemzetközi szervezetek programfejlesztési és projekt-tervezési követelményeinek megismertetését és teljesítését, $d$ ) gyújti és feldolgozza az ifjúságra vonatkozó regionális információkat, ennek érdekében kutatásokat, felméréseket kezdeményezhet, illetve támogathat, e) javaslatokat tesz a fiatalok részvételének fejlesztésére a helyi, a térségi, a regionális, a régiók közötti és az euro-regionális együttmúködésekben, $f$ ) az erre a célra rendelkezésre álló pénzügyi keret terhére biztosítja a Regionális Ifjúsági Tanács múködésének feltételeit, és ellátja a Regionális Ifjúsági Tanács múködésével összefüggő feladatokat
} 
ségi programok tervezéséhez és megvalósításához; képzéseket szervez a regionális programok, a térségi és a helyi projektek eredményes megvalósítása érdekében; részt vesz az ifjúsági közösségek, illetve projektek vezetőinek, az ifjúságsegítő szakembereknek a képzésében, valamint önkormányzati tisztségviselők és köztisztviselők továbbképzésében és információkat szolgáltat az ifjúsággal kapcsolatos döntések megalapozásához.

Ki kell emelnünk a DARISZI szolgáltatói tevékenységei közül a regionális, valamint a Duna-Körös-Maros-Tisza Eurorégióban (Triplex Régió) is fejlesztő hatással bíró projektek tervezéséhez való információs tanácsadást (ICSSZEM, GYIA, Ifjúság 2000-2006 Program, DARIT pályázatok), valamint közremúködést a megvalósításában, a nemzetközi pályázatokhoz való partnercsoport keresést, illetve a közösségek vezetőinek, projektvezetôknek, ifjúságsegítő szakembereknek és önkénteseknek nyújtott információ és adatszolgáltatást, valamint tájékoztató napok, tanulmányutak, képzések, szemináriumok és konferenciák szervezését. Az iroda új tevékenységi területeként szerepel a települési ifjúsági koncepciók kidolgozásában való közremúködés.

A DARISZI nyomtatott információs kiadványt (Róna) és elektronikus hírlevelet (Péntek) jelentet meg, melyek szerkesztési elvét az aktualitásra való törekvés (információk belföldi és nemzetközi pályázati lehetőségekről, hírek ifjúsági szervezetek részére) és a regionális ifjúsági tér szereplőit és eseményeit bemutató anyagok közlése, dokumentálás alkotják (tudósítások a régióban történó rendezvényekről, képzésekről, programokról). Mindkét médiaterméknek a célközönséghez való eljutatását az iroda végzi, az olvasói visszajelzések pozitívak.

A nemzetközi területen a DARISZI elsősorban az Európai Bizottság és az Európai Parlament által létrehozott Ifjúság 2000-2006 Programmal és a minisztérium által kiírt pályázatokkal foglalkozik. A nemzetközi programokkal kapcsolatban információs és tanácsadói napokat, illetve szakmai képzéseket szervez. Az iroda célja, hogy a jövőben minél több sikeres pályázat szülessen a régióban, illetve a pályázatok által minél több ifjúsági szervezet, és fiatal kapjon lehetőséget nemzetközi kapcsolatok építésére, az Európai Unió megismerésére és az Európai Unión belüli érvényesülésre.

Az iroda 2005. évi prioritásaiként a következóket emeli ki: az ifjúsági demokrácia erősítése a régióban; forrásteremtés az ifjúsági és civil szervezetek részére; Ifjúság 2000-2006 Program minél jobb kihasználása a dél-alföldi ifjúsági és civil szervezetek részére; HÍD (határmenti együttmúködés) elősegítése. Fontos fejlesztési irány az úgynevezett eDARISZI kialakítása, ami az iroda informatikai- és médiaismeretekkel rendelkező munkatársainak részvételével 
folyhat; jelenleg a Dél-alföld Portál (www.del-alfold.hu) és az információs hírlevél (Péntek) keretén belül.

A RISZI pályázatkezelő tevékenységéról a következőket mondhatjuk el. A dél-alföldi ifjúsági civil szervezetek az információszolgáltató, tanácsadó, képző tevékenységén kívül a leginkább a pályázatok kezelésén keresztül kerül kapcsolatba a DARISZI-vel. Az Európai Unió tagjaként Magyarország decentralizált támogatási rendszert alkalmaz az ifjúsági szcenárióban is. (13. grafikon)

A DARIT-pályázatokmegoszlása

(Összehasonlító adatok, db)

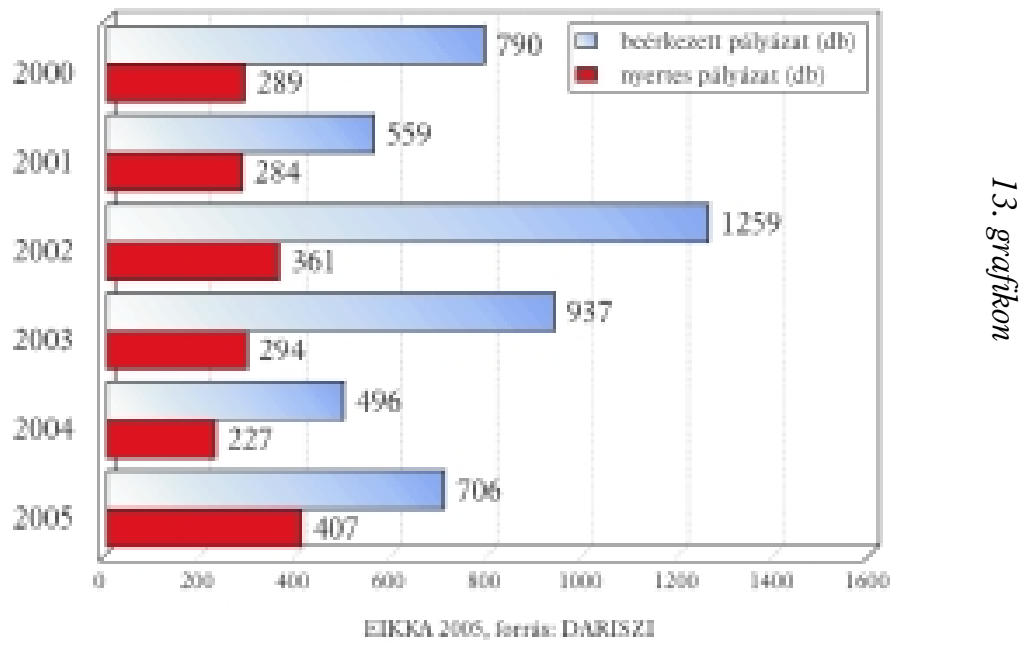

A DARISZI által kezelt pályázatok általában éves programokat támogatnak, projekttámogatással, utólagos finanszírozással. A DARIT által meghirdetett múködési, program és eszköztámogatási pályázatok jellegének megoszlását és egymáshoz viszonyított súlyát jól megfigyelhetjük a pályázati keretösszegeken. Múködési támogatásra 2,7 millió Ft-os, eszköztámogatásra 11,5 millió Ft-os és programfinanszírozásra 194,9 millió Ft-os keret kiosztása történt meg.

Az iroda feladata a döntésre való előkészítés (szakértőkkel való kapcsolattartás, anyagok rendezése, statisztikai és tartalmi elemzése) mellett az ellenorzés, a lezárás, az archiválás, a pályázati dokumentációk elkészítése és ôrzé- 
se. Az iroda legnagyobb pályázati munkaterületét a Dél-alföldi Regionális Ifjúsági Tanács (DARIT) felhívásaira beérkezett pályázatok adják. (14., 15. grafikon)
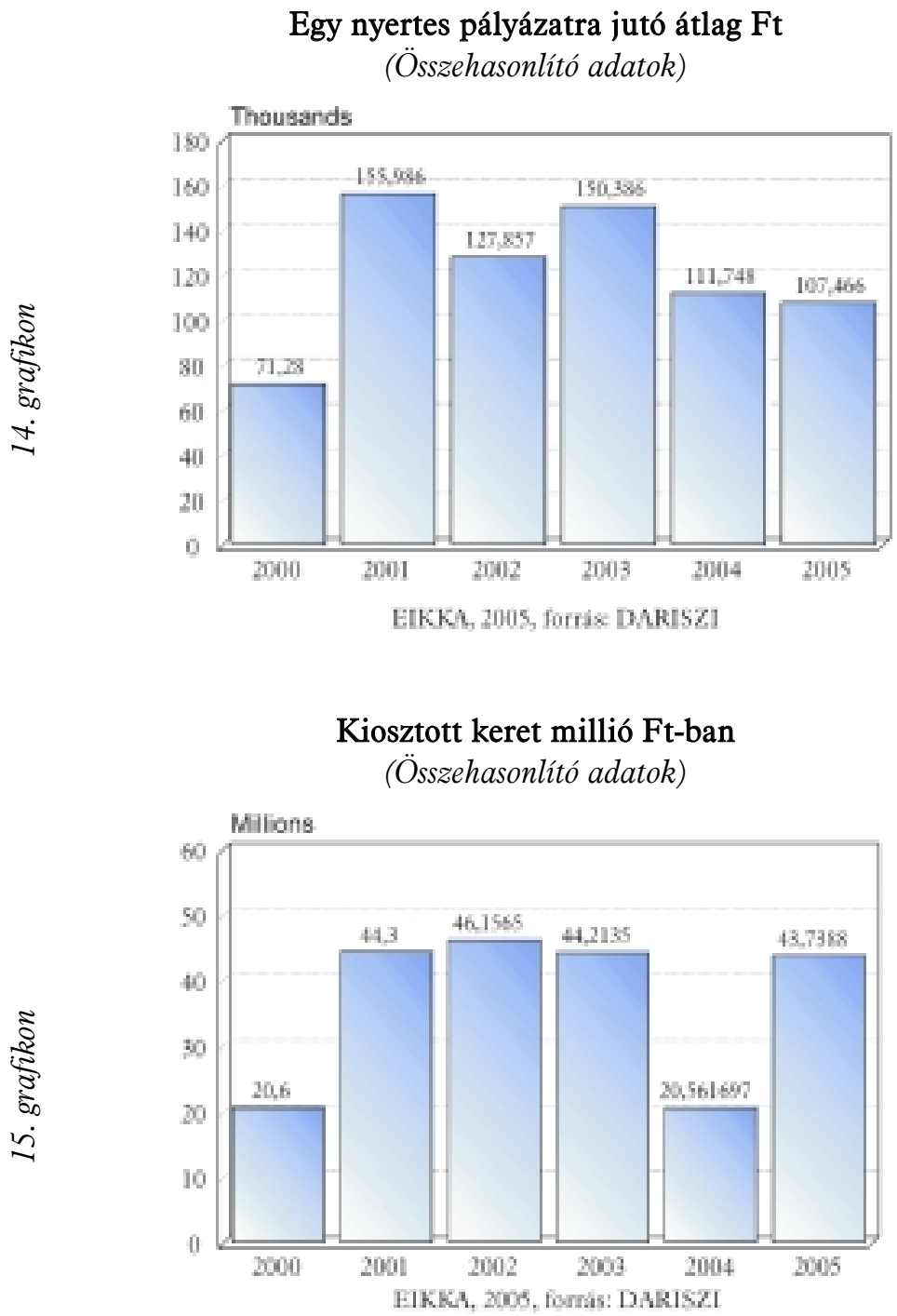

- 30 • 
A DARIT e pályázati rendszeren keresztül segíti, támogatja a települési önkormányzatok, a lokális és területi társadalmi szervezetek, alapítványok, intézmények és közösségek gyermek-, és ifjúsági munkáját. Az iroda eddigi múködése alatt összesen 4.747 RIT-pályázatot gondozott. Mindebből a nyertes pályázatok száma 1.862 volt, melyekre összesen 219.570 .247 forintot fordított. A DARIT-pályázatok időbeli megoszlását a következő ábra szemlélteti. Elmondhatjuk, hogy a pályázati aktivitás (a 2002. évi kiugró adatok mellett is) ingadozó, ugyanakkor a nyertes pályázatok száma 2005-re csaknem kétszerese az előzó évinek. Mindez arra engedne következtetni, hogy a nyertes pályázati összegek aprózódásának lehetünk tanúi, azonban a keretek éves változását vizsgálva mást állapíthatunk meg (d 16., 17. grafikon és 1. táblázat). A DARIT-pályázatok keretei a következőképpen alakultak (kerekített adatok, M Ft) 2000: 20,6; 2001: 44,3; 2002 46,1; 2003: 44,2; 2004: 20,5; 2005: 43,7. Az iroda eddigi múködése alatti egy nyertes pályázatra eső összeg: $117.000 \mathrm{Ft}$.

A regionális kiírásokra pályázók jogi státuszát vizsgálva azt mondhatjuk, hogy arányaiban az önkormányzati szektorból érkező pályázatok visszaesése, és az úgynevezett civil szféra, a klasszikus civil szerveződési formák (alapítványok, egyesületek) erősödése jellemző.

\section{A nyertes pályázók jogi státusz szerinti megoszlása}

(Az összes felosztott keret százalákában)

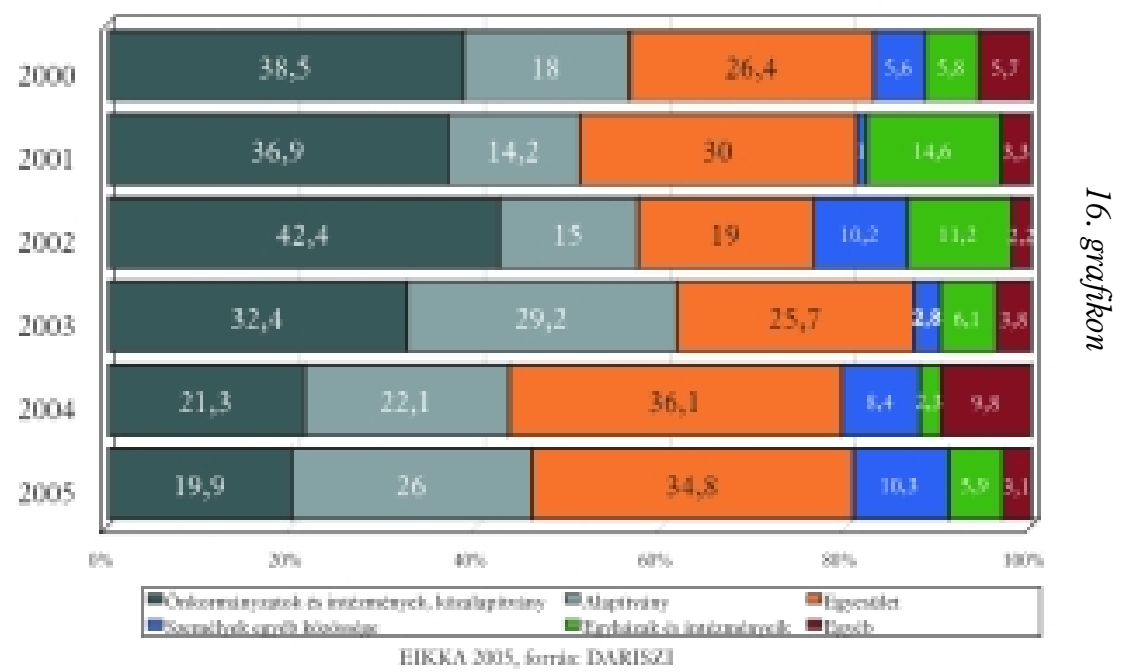




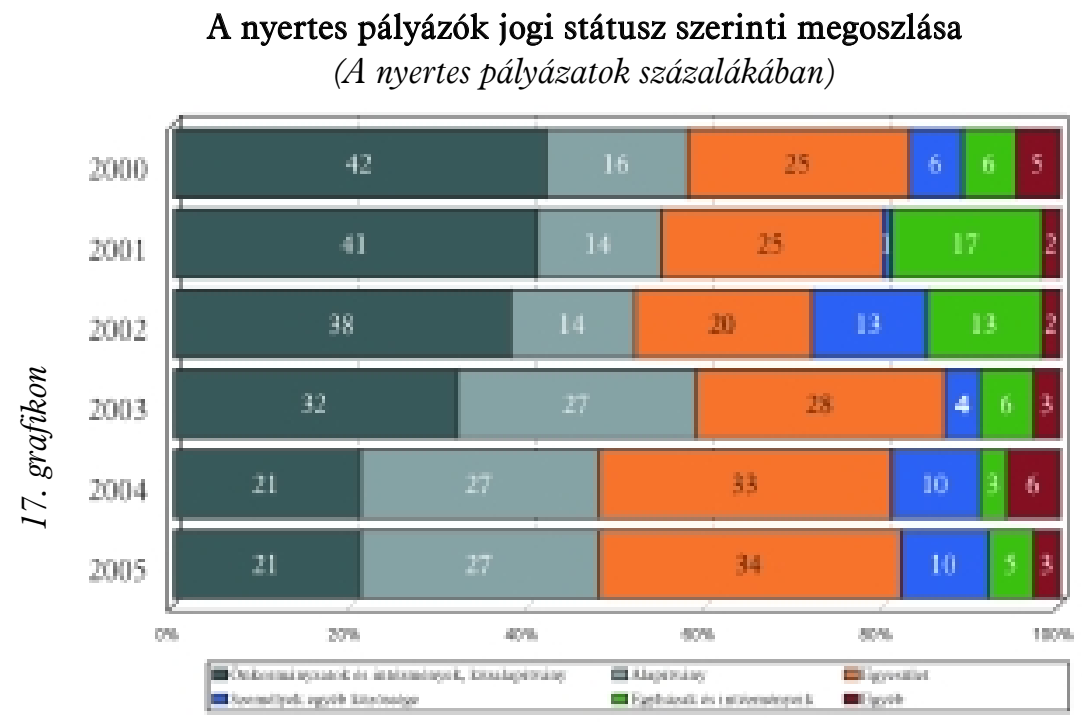

EIKKA 2005, forris: DARISZI

1. táblázat

\begin{tabular}{|l|c|c|c|c|c|c|}
\hline \multirow{2}{*}{ jogi státusz } & \multicolumn{2}{|c|}{2000} & \multicolumn{2}{c|}{2001} & \multicolumn{2}{c|}{2002} \\
\cline { 2 - 8 } & $\begin{array}{c}\text { Nyertes } \\
(\mathrm{db})\end{array}$ & $\begin{array}{c}\text { Megítélt } \\
\text { támogatás } \\
\mathrm{Ft}\end{array}$ & $\begin{array}{c}\text { Nyertes } \\
(\mathrm{db})\end{array}$ & $\begin{array}{c}\text { Megítélt } \\
\text { támogatás } \\
\mathrm{Ft}\end{array}$ & $\begin{array}{c}\text { Nyertes } \\
(\mathrm{db})\end{array}$ & $\begin{array}{c}\text { Megítélt } \\
\text { támogatás } \\
\mathrm{Ft}\end{array}$ \\
\hline $\begin{array}{l}\text { Önkormányzatok és } \\
\text { intézmények, } \\
\text { közalapítvány }\end{array}$ & 122 & 7944500 & 117 & 16341000 & 139 & 19570250 \\
\hline Alapítvány & 46 & 3710000 & 40 & 6307000 & 50 & 6927000 \\
\hline Egyesület & 71 & 5430000 & 72 & 13309000 & 73 & 8775000 \\
\hline $\begin{array}{l}\text { Személyek egyéb } \\
\text { közössége }\end{array}$ & 18 & 1145500 & 2 & 410000 & 46 & 4685000 \\
\hline $\begin{array}{l}\text { Egyházak és } \\
\text { intézményeik }\end{array}$ & 17 & 1205000 & 47 & 6468000 & 47 & 5180000 \\
\hline Egyéb & 15 & 1165000 & 6 & 1465000 & 6 & 1019000 \\
\hline \multicolumn{1}{|c|}{ ÖSSZESEN } & 289 & 20600000 & 284 & 44300000 & 361 & 46156250 \\
\hline
\end{tabular}




\begin{tabular}{|l|c|c|c|c|c|c|}
\hline \multirow{2}{*}{ jogi státusz } & \multicolumn{2}{|c|}{2003} & \multicolumn{2}{c|}{2004} & \multicolumn{2}{c|}{2005} \\
\cline { 2 - 8 } & $\begin{array}{c}\text { Nyertes } \\
(\mathrm{db})\end{array}$ & $\begin{array}{c}\text { Megítélt } \\
\text { támogatás } \\
\mathrm{Ft}\end{array}$ & $\begin{array}{c}\text { Nyertes } \\
(\mathrm{db})\end{array}$ & $\begin{array}{c}\text { Megítélt } \\
\text { támogatás } \\
\mathrm{Ft}\end{array}$ & $\begin{array}{c}\text { Nyertes } \\
(\mathrm{db})\end{array}$ & $\begin{array}{c}\text { Megítélt } \\
\text { támogatás } \\
\text { Ft }\end{array}$ \\
\hline $\begin{array}{l}\text { Önkormányzatok és } \\
\text { intézmények, } \\
\text { közalapítvány }\end{array}$ & 94 & 14322500 & 38 & 4369750 & 85 & 8705000 \\
\hline Alapítvány & 80 & 12890850 & 49 & 4552812 & 108 & 11367000 \\
\hline Egyesület & 81 & 11352000 & 62 & 7425500 & 137 & 15238800 \\
\hline $\begin{array}{l}\text { Személyek egyéb } \\
\text { közössége }\end{array}$ & 11 & 1256700 & 19 & 1727135 & 41 & 4505000 \\
\hline $\begin{array}{l}\text { Egyházak és } \\
\text { intézményeik }\end{array}$ & 19 & 2716450 & 5 & 461500 & 22 & 2563000 \\
\hline Egyéb & 9 & 1675000 & 11 & 2025000 & 14 & 1360000 \\
\hline \multicolumn{1}{|c|}{ ÖsSZESE N } & 294 & 44213500 & 184 & 20561697 & 407 & 43738800 \\
\hline
\end{tabular}

\section{A DARISZI főbb együttmúködő partnerei}

- Ifjúsági, Családügyi, Szociális és Esélyegyenlőségi Minisztérium

- MOBILITÁs

- Dél-alföldi Regionális Ifjúsági Tanács

- Dél-alföldi Regionális Területfejlesztési Tanács

- DKMT Eurorégió Ifjúsági Szövetsége

- AGORA irodák

- Ifjúsági Információs és Tanácsadó Irodák (HAYICO)

- Teleházak, Civil Házak, Esélyek Háza

- Gyermekekkel és Ifjúsággal foglalkozó szervezetek (egyesületek, alapítványok, egyházi fenntartású ifjúsági szervezetek)

- Települési önkormányzatok, ifjúsági referensek

- Kistérségi Önkormányzati Társulások (kistérségi megbízottak és kistérségi menedzserek)

- Ifjúsági közösségek (HÖK, DÖK, GYIÖK, ifjúsági klub, cserkészcsapat, egyházi ifjúsági csoport)

- A pályázatokat értékelő szakértők

- A régió oktatási-képzési szakemberei

- Önkormányzati fenntartású intézmények (múvelődési házak, ifjúsági házak, iskolák, óvodák) 


\subsection{HISZI-k tevékenységei ${ }^{9}$, szolgáltatásai, fejlesztési lehetőségei}

A helyi ifjúsági szolgáltató irodák (HISZI) létrehozását, azok országos lefedettséget mutató hálózata kialakításának szándékával, 2003-ban pályázat meghirdetésével támogatta a kormányzat. A települési ifjúsági szolgáltató iroda létrehozásának céljára meghirdetett támogatási felhívásra pályázatot a 2003. évben kizárólag önkormányzatok nyújthattak be. A dél-alföldi régióból három nyertes pályázat érkezett, mindhárom megyeszékhelyről. A pályázati feltételt (az iroda létrehozását) mindegyik pályázó teljesítette. Az azonban már megmutatkozott, hogy az iroda létéhez, a projektek fenntartható fejlődésének biztosításához, illetve a továbbéléshez hosszú távú fejlesztési és múködési forrásokat kell biztosítania a fenntartónak.

2004-re azzal, hogy civil szervezetek is beletartozhattak a pályázók közé, a pályázók köre kiszélesedett. A régióban Békéscsabán és Kecskeméten jött létre új iroda, a pályázaton elóbbit a Diáktanya Közalapítvány, utóbbit a HELPI

${ }^{9}$ A HISZIK tevékenységének bemutatásakor nem hagyhatjuk figyelmen kívül az első ilyen célú magyarországi civil szövetséget a HAYICO-t, amely az ifjúsági információs tanácsadó irodák hálózatát kívánja összefogni . „Hisszük, hogy a szabadság az emberi élet teljességének egyik alapfeltétele. Szabadon élni az életet azt is jelenti; az embereknek fenntartások nélkül joguk van hozzájutni a teljes, érthető és megbízható információkhoz kivétel nélkül minden őket érintő problémában és szektorban, hogy ezáltal a választás teljes szabadságát élvezhessék diszkrimináció, ideológiai vagy más befolyásolás nélkül. A fiataloknak hétköznapi problémáik megoldásában, életútjuk, jövőjük tervezésében és sorsukat befolyásoló döntéseik meghozatalában csakis akkor van valódi szabadságuk, ha széles körben rendelkeznek információkkal az őket körülvevő világról.” (HAYICO Szakmai-etikai Kódex) A Magyarországi Ifjúsági Információs és Tanácsadó Irodák Szövetsége (Hungarian Association of Youth Information and Counselling Offices) a fentiekben leírtak szellemében jött létre 1990-ben. Az alapítók - a magyarországi ifjúsági információs és tanácsadó irodák - szándéka szerint a HAYICO múködésének elsődleges céljai: - Az aktív szerepvállalás az ifjúság problémáinak feltárásában, nyilvánosságra hozatalában, a problémák megelőzésében és kezelésében,

- az ifjúsági információs és tanácsadó irodák támogatása abban, hogy a fiatalokat érdeklő és érintő információkat hatékonyan, eredményesen gyüjtsék, kezeljék és szolgáltassák ügyfeleik számára,

- az ifjúsági információs és tanácsadó irodák tevékenységének összehangolása, olyan hálózati szolgáltatások nyújtása, amelyek a kölcsönös segítségnyújtás elvén múködnek, - az ifjúsági információs és tanácsadó irodák érdekképviseletének ellátása hazai és nemzetközi viszonylatokban. 
nyerte. Szegeden az Ifjúsági Ház (IH) mellett a SZITI Egyesület indított irodát a program támogatásával.

Mindeközben a HISZI-k szerepköre is átalakult, a korábbi szolgáltató feladatok mellett egyre inkább hangsúlyt kaptak az úgynevezett tanácsadó szerepek, feladatok. A tanácsadások közül az életvezetési és életszervezési, valamint a pályaorientációs tanácsadás, illetve a pszichológiai- és mentálhigiénés tanácsadások mellett, megmaradtak a "hagyományos” információszolgáltató feladatok is (helyi, regionális és országos kulturális és sportprogramokról, ifjúságot, ifjúságsegítóket, pedagógusokat érintő képzésekről, helyi sportolási lehetőségekről, közoktatási és felsőoktatási információkról, egészségügyi és szociális ellátásokról, a korosztályt érintő törvények és jogszabályokról és az érdekérvényesítési lehetőségekről (személyiségi és oktatási jogok), valamint a közigazgatási szervek és egységek munkájáról, és az ifjúsági korosztályt érintő stratégiai és más önkormányzati döntésekről-tervezetekről, valamint különféle európai, országos és helyi pályázatokról)

A regionális iroda munkatársai helyesnek tartják, hogy a helyi irodára pályázók köre kibővült és már civil szervezetek is pályázhatnak.

A jelenlegi négy iroda pótolhatatlan tanácsadó és fejlesztő feladatokat is vége ${ }^{10}$, hatásuk helyi szinten erőteljes lehet, ám egy regionális hálózat kialakításához erősebb alapot jelentene, ha minden városban (megyei jogú városok száma: 4, 20.000 fó feletti városok: $9 \mathrm{db}$, városok: $31 \mathrm{db}$ ) létrehozásra kerülne helyi ifjúsági szolgáltató iroda, és a hosszú távú fenntarthatóság feltételei biztosítottak lennének.

A HISZI-k múködésének szakmai fejlesztési irányait meghatározhatják az úgynevezett Civil Szolgáltató Központokkal és a települési önkormányzatokkal való fokozott kapcsolati rendszer kialakítása, így a helyi ifjúsági munka koordinációs szereplőjévé válás (katalizátor szerep). Mindehhez azonban az önkormányzatoknak (bizottsági, közgyưlési és polgármesteri szinten) és a politikai szereplőknek (egyaránt és egységesen), tehát a „felnőtt világnak” foko-

\footnotetext{
${ }^{10}$ A célközönség alatt természetesen a felsőoktatási életszakasz kezdetéig értjük a fiatalokat, ugyanis ott, tehát az egyetemeken-főiskolákon kiterjedt, ugyanakkor megfelelő anyagi és emberi erőforrásokkal rendelkező tájékoztató, tanácsadó és szolgáltató irodák működnek intézményi fenntartással, illetőleg civil (HÖK, Alapítvány, Egyesület, Kht.) múködtetéssel, és Oktatási Minisztériumi támogatással, melyeknek országos ernyőszervezetük a HASZOSZ (Hallgatói Szolgáltatók Országos Szövetsége) is létrejött az évezred elején. Ez persze nem zárja ki, hogy az adott fiatal (már mint felsőoktatási hallgató) visszajárjon a HISZI tájára, s van is erre példa.
} 
zott figyelmet szükségeltetik fordítani „az ifjúság helyzetének jobb megértése” - mint Európai Uniós tétel - tartalmára is, a megfelelő állandó források, tervezhető és kiszámítható pályázati lehetőségek biztosítására és ugyanakkor a sok helyütt hiányzó közösségi terek megteremtésére, fejlesztésére.

\subsection{Közösségi terek (Ifjúsági házak, teleházak, klubok, ifjúsági fesztiválok)}

Ifjúságpolitikai helyzetkép

\begin{tabular}{|c|c|c|c|c|}
\hline $\begin{array}{c}\text { Közigazga - } \\
\text { tási szint }\end{array}$ & Bács-Kiskun & Békés & Csongrád & Dél-alföldi régió \\
\hline Ifjúsági ház & 3 & 4 & 4 & 11 \\
\hline Ifjúsági klub & 44 & 31 & 31 & 106 \\
\hline $\begin{array}{l}\text { Fesztivál, } \\
\text { rendezvény }\end{array}$ & $\sim 28$ & $\sim 329$ & $\sim 24$ & $\sim 381^{11}$ \\
\hline
\end{tabular}

\section{Ifjúsági házak ${ }^{12}$}

A dél-alföldi régióban Bács-Kiskun megyében 3, Békés és Csongrád megyében pedig 4-4 - kifejezetten a fiatalok számára létesített - ifjúsági ház múködéséről van tudomásunk. Természetesen ennél lényegesen több azoknak a

\footnotetext{
${ }^{11}$ A Bács-Kiskun Megyei Közmúvelődési Intézet és a Csongrád Megyei Közmúvelődési Tanácsadó Központ honlapja nem tartalmazott értékelhető információt a megyében megrendezésre kerülő rendezvényekrôl, ezért a NKÖM-IStAR idevonatkozó adatait használtuk. A Békés megyei adatokat a Békés Megyei Múvelődési Központ honlapján található rendezvénynaptárban összegyüjtött és folyamatosan frissített rendezvénytárból nyertük, melyben az összes települési szintû rendezvény megtalálható, amik többsége minden korosztálynak - így az ifjúságnak is - szóló esemény.

${ }^{12}$ Ifjúsági házakkal kapcsolatos felmérés 2002-ben jelent meg: Szabó Andrea - Kovács Szilvia - Bitter Brúnó - Bauer Béla: Gyermek-, múvelődési és ifjúsági házak 2001 címmel. A kötet definiálja az ifjúsági ház fogalmát: „az ifjúsági ház egy olyan nyitott, mindig a fiatalok rendelkezésére álló kulturális intézmény, amelyben öntevékeny közösségek múködnek, és ahol a látogatók legnagyobb részét az ifjúsági korosztály teszi ki.”, 91 Bár a felmérés és adataik országosak, a tendenciákat jól mutatják: „az ifjúsági házak száma visszaesett a '80-as évekbeli fénykorszakhoz képest (4000); ennek elsősorban a szórakoztató-piacon megjelenő új szereplők az oka (klubok, diszkók, fesztiválok és a '90-es évek közepétől a plázák is). Ma így körülbelül az 1970-es évek elejének szintjére esett vissza az ifjúsági klubok száma (1970 - 2200 db; 1997 - 2500 db ifjúsági klub)”. (Szabó et.al. 2002, 29)
} 
közmúvelődési intézményeknek a száma, ahol a fiatalok számára is szerveznek programokat. Ennek ellenére úgy gondoljuk, hogy kiemelkedő fontossággal bírnak ezek a házak, hiszen a legtöbb településen ez az egyetlen, az ifjúság számára biztosított közösségi színtér.

Az ifjúsági házak szolgáltatásai között megtalálható az ingyenes internetezési lehetőségen és a programszervezésen túl az önszerveződő ifjúsági csoportok (pl. amatôr zenekarok) tevékenységéhez szükséges helyiségek biztosítása, a különböző klubok üzemeltetése (pl. filmklub, színjátszóklub). A fentiekből következik, hogy ezek az ifjúsági színterek alkalmasak lehetnek az ifjúság informálására olyan formában, hogy a rendelkezésre álló tájékoztató anyagokat az intézménybe látogatók számára elérhetővé teszik.

\section{Ifjúsági klubok}

Az összefoglaló táblázatban szereplő számadatok kizárólag azokat az ifjúsági klubokat tartalmazzák, melyek az NKÖM-IStAR adatfelvétele során e besorolás alá estek. Így nem tartalmazza azokat a klubokat, melyek közönségének jelentős része szintén fiatal, de konkrét szervezőelv alapján múködnek (pl. táncklubok, olvasókörök, képzómúvészeti csoportok, stb.) A fent említett kutatásban az összes közművelődési intézmény adatai szerepelnek, de természetesen nem csak e kereteken belül múködnek klubok, így a tényleges számuk nem meghatározható. ${ }^{13}$

\section{Fesztiválok, rendezvények}

$\mathrm{Az}$ adatgyújtés során meglehetősen nagy gondot okozott a régióban megrendezésre kerülő fesztiválok számszerúsítése, hiszen nem áll rendelkezésre egyetlen adatbázis sem, ahol egy teljes év - vagy akár egy régió, egy megye programterve megtalálható lenne. Így, a teljesség igénye nélkül, csak megközelítő adatot tartalmaz a táblázat a régiós fesztiválokkal kapcsolatban ${ }^{14}$.

\footnotetext{
${ }^{13}$ A klubok legfóbb szervezőelve a fiatalok szabadidejének hasznos eltöltése; mert szívesen töltik idejüket informális csoportokban, barátaik között. Ezek a klubok kiváló lehetőséget ad(hat)nak az öntevékeny közösségi élet (ki)alakítására, hiszen a rendszeres találkozások alkalmat adnak a részvételre, az önkéntességre. Ha ezt felismerve van egy olyan hely, ahol ki tudják képességüket, tehetségüket bontakoztatni, az a fiatalok közösségi tevékenysége a helyi közösség, település javát szolgálhatja.

${ }^{14}$ Pedig a fiatalok hasznos szabadidő-eltöltésének fontos, és hasznos közösségépítő teret biztosítanak a különböző ifjúsági fesztiválok. Ezek a rendezvények nemcsak azért fontosak, mert megyei, regionális szinten vonzzák az érdeklődőket, hanem országos
} 
A fesztivál ifjúsága témakörben a régióban is szükséges volna egy komplex kutatási program elindítása.

\section{Teleházak}

A Teleházak hálózata az 1990-es évek első harmadától sajátságos hatással van a Dél-alföldi ifjúsági szcenárióra. Azt a törekvést, hogy az adott Teleház egyfajta közösségi térként (sőt ifjúsági közösségi térként) is múködjön jól kifejezi a szövetségük által meghatározott szolgáltatási minimum, amely egyúttal „Teleház” név használatának feltételrendszere is: „Internet-használat biztosítása; elektronikus levelezés (e-mail cím) biztosítása; számítógép-használat biztosítása; számítógépes munkák végzése (szövegszerkesztés, nyomtatás, scannelés, gépelés, szórólapplakát-készítés, névjegykártya készítés); számítógépes játék; faxküldés és fogadás; ügyintézéshez segítségnyújtás és közremúködés; civil szervezetek kiszolgálása, civil központi funkciók; közhasznú tájékoztatás; prospektustár, tájékoztató lapok szolgáltatása; helyi hirdetési és hírközpont; pályázatfigyelés, -írás és pályázati tanácsadás; oktatás és képzések szervezése (nem csak számítógépes)"'15. Az ifjúsági szektorban speciális feladatokat ró a Regionális Ifjúsági Szolgáltató Irodára a régióban létező 25 kistérség, úgy véljük e téren nélkülözhetetlen a szoros együttmúködés a Teleházakkal. (2. táblázat)

\begin{tabular}{|c|c|c|c|c|c|c|c|c|c|c|}
\hline \multirow[b]{3}{*}{ Regionális Ifjúsági } & \multicolumn{3}{|c|}{$\begin{array}{l}\text { Bács-Kiskun } \\
\text { megye }\end{array}$} & \multicolumn{3}{|c|}{$\begin{array}{l}\text { Békés } \\
\text { megye }\end{array}$} & \multicolumn{3}{|c|}{$\begin{array}{c}\text { Csongrád } \\
\text { megye }\end{array}$} & \multirow{2}{*}{$\begin{array}{l}\text { Dél-alföldi } \\
\text { régió }\end{array}$} \\
\hline & $\mathrm{k}$ & $\mathrm{V}$ & $\mathrm{mjv}$ & $\mathrm{k}$ & \begin{tabular}{l|l}
$\mathrm{V}$ & $\mathrm{r}$ \\
\end{tabular} & $\mathrm{mjv}$ & $\mathrm{k}$ & $\mathrm{v}$ & $\operatorname{mjv}$ & \\
\hline & - & - & - & - & - & - & - & - & 1 & 1 \\
\hline $\begin{array}{c}\text { Helyi Ifjúsági } \\
\text { Szolgáltató Iroda }\end{array}$ & - & - & 1 & - & - & 1 & - & - & 2 & 4 \\
\hline Teleház & 16 & 5 & 1 & 12 & 2 & - & 31 & 3 & 3 & $73^{16}$ \\
\hline
\end{tabular}

k=község, $v=$ város, mjv=megyei jogú város

- sőt, nemzetközi szinten is. Nagyon jó példa régiónkból a Szegedi Ifjúsági Napok, a Kelebiai Kárpát Fesztivál, az Erkel Diákünnepek, a Garabonciás napok és a számtalan egyetemi, főiskolai fesztivál. Külön említést érdemel a Dél-alföldi Regionális Ifjúsági Tanács immáron harmadjára kiírt pályázati lehetősége, amely a dél-alföldi régió gyermek és ifjúsági együttműloödési fóruma és kiállítása. A fesztiválozó ifjúságról ld. még Gábor Kálmán az irodalomjegyzékben szereplő publikációit.

${ }^{15} \mathrm{http}: / /$ www.telehaz.hu/hosted/pagel/telehazminimum_2005.pdf

${ }^{16}$ Forrás: www.telehaz-del-alfold.hu 


\subsection{Drogprevenciós szolgáltatások, intézmények ${ }^{17}$}

Az 1998-óta folyó kutatások ${ }^{18}$ (kutatásvezetô: Gábor Kálmán) alapján általánosságban elmondhatjuk, hogy a fiatalokat érintő kihívások és a növekvő kockázatok, a fokozódó verseny, a korai önállósodás (a gyermekkor elvesztése) és a későbbi felnőtté válás jelentősen megnöveli a fiatalok veszélyeztetettségét a dohányzás, az alkohol- és a drogfogyasztás területén. Az úgynevezett feszültségoldó technikák alkalmazása (alkoholfogyasztás, droghasználat) egyrészt kapcsolódik egy sajátos életformához (például lehetnek az intenzív szabadidő eltöltés velejárói), vagy adódhatnak olyan életformaminták átvételéből, amiket a szórakoztatóipar kínál (techno, rave, trance), de adódhatnak azokból a feszültségekből is, amiket a fiatalok saját identitásuk kialakítása során keletkeznek, másrészt bizonyos elkülöníthetô rétegekben gyakoribb az előfordulásuk. Ugyanakkor sajnos azt kell mondanunk, hogy akik kipróbálják a drogot, azt egyre fiatalabb korban próbálják ki.

Mindemellett fontos tényező az, hogy a saját identitás kialakításának folyamata a kortárscsoportban zajlik, ezért tehát a fiatalok számára felértékelődik a kortárscsoport szerepe (ugyanakkor gyengülnek a hagyományos állami és családi ráhatások). Azt látjuk, hogy kortárscsoport mintaadó szerepe pedig olyan körülmények között erősödött fel, amikor a fiatalok identitáskeresése közben egyre kevesebb szerepet játszanak az iskola, az ifjúsági szervezetek és az ifjúsági intézmények. Vizsgálataink azt mutatják, hogy a fiatalok egy része mintegy menekül a feszültségoldó technikák alkalmazásába, és

\footnotetext{
${ }^{17}$ Felismerve a drogproblémából fakadó társadalmi és gazdasági veszélyeket az Ifjúsági és Sportminisztérium megalkotta a Nemzeti stratégiát a kábítószer-probléma visszaszorítása érdekében címú dokumentumot, melyet a Kormány 2000. július 4én, az Országgyúlés 2000. december 5-én fogadott el. (96/2000. [XII. 11.] OGY határozat a kábítószer-probléma visszaszorítása érdekében készített nemzeti stratégiai program elfogadásáról) A Nemzeti stratégia nem csupán drogellenes program, hanem szándéka és szemlélete alapján ennél lényegesen több: egy egészségében tudatos, azt megtartani, sőt továbbfejleszteni képes és kész Magyarország jövőképe is. Ebben a vonatkozásban nemcsak a településeknek (NUTS V. szint) hanem a kistérségeknek (NUTS IV.) és megyéknek (NUTS III.) is óriási lehetőségük és természetesen felelősségük van.

${ }^{18}$ Gábor Kálmán: Társadalmi átalakulás és ifjúság - A szabadság mint esély. 2000; Gábor Kálmán: A középosztály Szigete. 2002; Gábor Kálmán: Fesztiválok ifjúsága és a drog. 2005.
} 
ők pedig azok, akik a szabadságot, az érdekes változatos életet preferálják, azt is mondhatjuk, hogy azok alkalmazása számukra egyet jelent a szabadság élményével. ${ }^{19}$

$\mathrm{Az}$ igen súlyos és terebélyesedő társadalmi (és elsősorban az ifjúsági szcenáriót érintő) problémával kapcsolatban összehangolt kormányzati lépésekre, a civil szférával és a települési önkormányzatokkal szoros együttmúködésre van szükség. E körben a Regionális Ifjúsági Tanács és a települési ifjúságüggyel foglalkozó önkormányzati bizottságok szerepvállalása fokozottan szükséges. A régió érintettségét erősít a hármashatár közelsége és az úgynevezett tranzitútvonalak érintése, noha adatok nincsenek e tárgykörben, mégis feltételezhető, hogy ezek miatt a dél-alföldi fiatalok könnyebben kerülnek kapcsolatba a kábítószerekkel.

2005. márciusi adatok szerint a Dél-alföldi régióban 13 Kábítószerügyi Egyeztető Fórum (KEF) létezik. Ezek mindegyike kizárólag a városokban található, melyek helyi szinten múködnek, így ezek kistérségi hatása csekély. (3. táblázat)

Területi eloszlásban Bács-Kiskun megye vezeti a KEF-ek listáját, a megyében 6, Békésben 4, Csongrád megyében $3 \mathrm{KEF}$ múködik.

A Kábitószerügyi Egyeztető Fórumok megoszlása ${ }^{20}$

\begin{tabular}{|c|c|c|}
\hline \multirow{4}{*}{$\begin{array}{l}\text { Baja, Kalocsa, Kecskemét, Kiskunfélegyháza, } \\
\text { Kiskunhalas, Kiskunmajsa } \\
\text { Békés, Békéscsaba, Gyula, Orosháza } \\
\text { Hódmezóvásárhely, Szeged, Szentes }\end{array}$} & Bács-Kiskun megye & 6 \\
\hline & Békés megye & 4 \\
\hline & Csongrád megye & 3 \\
\hline & A régió összesen & 13 \\
\hline
\end{tabular}

„Nincs - a szenvedélybeteg és hajléktalan ellátást kivéve - társadalmi reintegrációt biztosító intézményi háttér és e célból a szektoron belüli, valamint szektorok közötti szolgáltatói együttmúködés sem, és minimális az utógondozás és a hatékony alternatív megoldások lehetősége. Kevés azoknak a szolgáltatóknak is a száma, akik szektorközi együttmúködésekre alapozott társadalmi re-integrációt szolgáló programokkal, illetve tapasztalattal rendelkeznek. [...] A gyermekvédelmi gondoskodásból (korábban állami gondoskodásból)

\footnotetext{
${ }^{19}$ Gábor Kálmán 2005:38

${ }^{20}$ Forrás: Mobilitás, Kutatási Iroda
} 
kikerülő fiatalok önálló életkezdési esélyei tekintetében a hátrányuk nem megfelelően kezelhető a mai gyakorlat szerint." ${ }^{\text {¹ }}$ A régió civil közösségének (és azon belül az ifjúsági szervezeteknek) azonban e területeken is fokozott szerepvállalására volna szükség, a természetesen hiányzó állami forintokon kívül, és azok mellett.

Azzal együtt, hogy az elmúlt években a kábítószert kipróbálók száma lassú arányban ugyan, de folyamatosan növekedett, ezért egyre nagyobb figyelem irányult a drogfogyasztás problémakörére. Tudjuk, hogy e szempontból a legveszélyeztetettebb a középiskolás korosztály ${ }^{22}$, ám a kipróbálók köre egyre fiatalabb generációkat érint.

Az elsö drogfogyasztás idôpontja ${ }^{23}$ :

A táblázat adatait megvizsgálva az mondható el, hogy a fiatalok nagy részének (88\%) elsó drogfogyasztása 14-15 éves kor környékén történik. Megdöbbentô az az adat, hogy a fiatalok 6\%-a 12 éves korában próbált ki elöször valamilyen drogot.

\begin{tabular}{|c|c|c|c|c|}
\hline \multirow{2}{*}{ A drog kipróbálásának idöpontja } & \multicolumn{5}{|c|}{} \\
\cline { 2 - 5 } & Idén & $1-2$ éve & $3-4$ éve & 5 éve \\
\hline 13 év & 0 & 0 & 0 & 0 \\
\hline 14 év & $100 \%$ & 0 & 0 & 0 \\
\hline 15 év & $50 \%$ & $50 \%$ & 0 & 0 \\
\hline 16 év & 0 & $100 \%$ & 0 & 0 \\
\hline 17 év & $22 \%$ & $67 \%$ & 0 & $11 \%$ \\
\hline \multirow{2}{*}{}
\end{tabular}

A kormányzat a legutóbbi években fokozott támogatási figyelmet szentelt a kábítószer-használattal kapcsolatos kutatások, szakmai anyagok és egyéb projektek finanszírozására, melyeknek a dél-alföldi régióra eső vetületét az alábbi összehasonlító táblázatokban tekintjük át. (4., 5. táblázat)

${ }^{21}$ Dél-alföldi Régió Helyzetelemzés. 2005.05 .06 (2. számú munkaanyag)

${ }^{22}$ Kecskemét város középiskolai felméréséről bővebben: Nagy Lászlóné: Önpusztító szenvedélyek veszélye a középiskolások között mért kutatási adatok tükrében. 2000.

${ }^{23}$ Manda Eszter: Alkohol-, nikotin és drogfogyasztás alakulása a fiatalok körében Szegeden In: www.mave.hu 
$A z$ úgynevezett $K A B$ pályázatok megoszlása

\begin{tabular}{|c|c|c|c|c|c|c|c|c|}
\hline \multicolumn{9}{|c|}{2000} \\
\hline & & \multicolumn{2}{|c|}{ pályázók száma } & \multicolumn{3}{|c|}{ nyertes pályázók száma } & \multicolumn{2}{|c|}{ nyert összeg } \\
\hline \multicolumn{2}{|c|}{ Bács-Kiskun } & \multicolumn{2}{|c|}{115} & \multicolumn{3}{|c|}{56} & \multicolumn{2}{|c|}{17.325 .000} \\
\hline \multicolumn{2}{|c|}{ Békés } & \multicolumn{2}{|c|}{85} & \multicolumn{3}{|c|}{30} & \multicolumn{2}{|c|}{7.950 .000} \\
\hline \multicolumn{2}{|c|}{ Csongrád } & \multicolumn{2}{|c|}{160} & \multicolumn{3}{|c|}{86} & \multicolumn{2}{|c|}{24.446 .000} \\
\hline \multicolumn{9}{|c|}{2001} \\
\hline & & \multicolumn{2}{|c|}{ pályázók száma } & \multicolumn{3}{|c|}{ nyertes pályázók száma } & \multicolumn{2}{|c|}{ nyert összeg } \\
\hline \multicolumn{2}{|c|}{ Bács-Kiskun } & \multicolumn{2}{|c|}{331} & \multicolumn{3}{|c|}{106} & \multicolumn{2}{|c|}{34.591 .200} \\
\hline \multicolumn{2}{|c|}{ Békés } & \multicolumn{2}{|c|}{243} & \multicolumn{3}{|c|}{74} & \multicolumn{2}{|c|}{22.096 .400} \\
\hline \multicolumn{2}{|c|}{ Csongrád } & \multicolumn{2}{|c|}{345} & \multicolumn{3}{|c|}{119} & \multicolumn{2}{|c|}{38.489 .800} \\
\hline \multicolumn{9}{|c|}{2002} \\
\hline \multirow{2}{*}{\multicolumn{2}{|c|}{ Bács-Kiskun }} & \multicolumn{2}{|c|}{ pályázók száma } & nyertes pá & lyázók számc & & nyer & tösszeg \\
\hline & & 33 & & & 147 & & 75. & 372.800 \\
\hline & Békés & 28 & & & 103 & & 40. & 97.154 \\
\hline & ongrád & 37 & & & 134 & & 70. & 551.050 \\
\hline & $\begin{array}{c}\text { pályáźḱ } \\
\text { szzma } \\
\text { (országos, } \\
\text { db) }\end{array}$ & $\begin{array}{c}\text { pályázók } \\
\text { száma } \\
\text { (Dél-alföld, } \\
\text { db) }\end{array}$ & $\begin{array}{c}\text { kért } \\
\text { osszeg } \\
\text { (országos, } \\
\text { Ft) }\end{array}$ & $\begin{array}{l}\text { kért össszeg } \\
\text { (Dél-alföld, } \\
\text { Ft) }\end{array}$ & $\begin{array}{c}\text { elnyert } \\
\text { támogatás } \\
\text { (orszagoss, } \\
\text { Ft) }\end{array}$ & & $\begin{array}{l}\text { yert } \\
\text { gatás } \\
\text { alföld, } \\
\text { t) }\end{array}$ & \begin{tabular}{|c} 
dél-alfö̈ldi \\
nyertes \\
pályázók \\
száma (db)
\end{tabular} \\
\hline 2000 & 3099 & 360 & 2.725 .815 .842 & 280.874 .349 & 726.970 .305 & & 1.000 & 172 \\
\hline 2001 & 6726 & 919 & 4.702 .580 .042 & 601.875 .023 & 766.788 .000 & & 7.400 & 229 \\
\hline 2002 & 6720 & 998 & 4.920 .103 .301 & 689.792 .917 & 129.1242 .838 & & 21.004 & 384 \\
\hline
\end{tabular}

\subsection{A régió településszerkezete, regionális jellemző ${ }^{24}$}

\section{A régió földrajzi jellemzői, sajátosságai röviden}

A Dél-alföldi Régió Kelet-Közép Európában, a Kárpátok által körülhatárolt medencében fekszik. A régió az ország délkeleti és déli területén, a Bács-Kiskun, Békés és Csongrád megye által lefedett területen helyezkedik el, az ország legnagyobb kiterjedésủ térsége. A régió északi, északnyugati területe az

\footnotetext{
${ }^{24}$ Alapvető forrásaink: www.nepszamlalas.hu; www.ksh.hu; www.del-alfold.hu; www.dkmt.hu; www.bacskiskun.hu; www.bekesmegye.hu; www.csongrad-megye.hu; Csatári - Lengyel - Nagy - Nagy (2005): A Dél-alföldi Régió Területfejlesztési koncepció felülvizsgálata. 2005.
} 
ország középső részéhez kapcsolódik, Békés és Bács-Kiskun megye egyes határ menti területei viszont az ország középpontjához képest meglehetősen periferikus területet képeznek. A régió délen Szerbia-Montenegróval határos, keleten Romániával. A régió területe $18.339 \mathrm{~km}^{2}$, az ország összterületének 19,7\%-a, az ország lakosságának 13,4\%-a él itt.

A régióban közel 1.400 .000 fő a lakosságszám, mely a régiók között közepesnek tekinthetó, azonban a 74 fó $/ \mathrm{km}^{2}$-es népsürüség lényegesen elmarad az országos átlagtól $\left(109 \mathrm{fő} / \mathrm{km}^{2}\right)$. A Dél-alföld 25 statisztikai kistérsége közül 7 tartozik az ország 48 leghátrányosabb kistérsége közé. A régión belüli térszerkezet vázát nem a statisztikai kistérségek, hanem más rendezőelvek mentén kialakuló, viszonylag homogén településcsoportok képezik. Ilyenek: a megyeszékhelyek (illetve részben Baja), szomszédos városaik és szuburbanizálódó övezeteik együtteséból formálódó városrégiók (illetve agglomerációk), melyek a régió legnagyobb kiterjedésű, összefüggő, dél-alföldi viszonylatban fejlett, erősen urbanizálódó, dinamikus pólusai. A régióra az egykori mezővárosok túlsúlya jellemző, de a terület nagyságához képest meglehetősen kevés, 254 település található csak itt. Az urbanizáció Közép-Magyarország után e régióban a legerőteljesebb, mivel az 1,377 milliós lakosság 67\%-a él városokban. (6. táblázat)

A dél-alföldi régió településeinek megoszlása (2005)

\begin{tabular}{|l|c|c|c|}
\hline & Bács-Kiskun & Békés & Csongrád \\
\hline Megyei jogú város & 1 & 1 & 2 \\
\hline 20 Efó fölötti város & 3 & 3 & 3 \\
\hline Város & 16 & 13 & 3 \\
\hline Község & 99 & 58 & 52 \\
\hline Összesen: & 119 & 75 & 60 \\
\hline
\end{tabular}

Alföldi jellegzetesség, az egymás szomszédságában fekvő, fontosabb közlekedési artériára felfüződő, többnyire tradicionális városok által kirajzolt viszonylag fejlett, urbanizált tengelyek (a Gyomaendrőd - Szarvas - Szentes Csongrád - Kiskunfélegyháza - Kecskemét - Lajosmizse vonal, valamint a Szeged - Hódmezővásárhely - Orosháza - Békéscsaba - Gyula vonal). A feldolgozott információk és szakirodalmak szerint kiemelhetjük, hogy az országés megyehatár menti külső, valamint a jelentősebb külterületi népességgel rendelkező falucsoportokból álló, városok közé is behatoló belső falusi perifériák jelentősen kedvezőtlenebb helyzetben vannak. 
A települések $42 \%$-át kitevő, regionális viszonylatban társadalmi-gazdasági szempontból elmaradott települések között a falvak és a városok egyaránt megtalálhatók. A városoktól távolabbi tanyás települések, a Kalocsa környéki aprófalvak, s különösen Bács-Kiskun, illetve Észak- és Dél-Békés határ menti területeinek évtizedek óta tartó lassú demográfiai eróziója folytatódik. A rurális települések csoportjában kiemelendőek a Dél-alföld településhálózatának leginkább karakterisztikus vonást adó, egyre nagyobb mértékben differenciálódó tanyák, amelyek szerves részét képezik számos falunak, de városnak is, s azoktól elválasztva semmiképp sem fejleszthetôk.

\section{A régió demográfiai helyzete}

A Dél-alföldi régió az ország harmadik legnépesebb régiója. Lakónépessége 2003-ban 1.372.702 fó, mely népességszám jó tíz évvel korábban, 1990-ben 1.427.938 fó volt, 1960-ban pedig meghaladta az 1 millió 500 ezer főt. (30. ábra) A népességcsökkenés folyamatos, bár nem egyenletes mértékú.

A Dél-alföld egy négyzetkilométerére átlagosan 74 ember jut, 35-tel kevesebb, mint az ország egészében. Három megyéje közül Csongrádban a legmagasabb, a nagy kiterjedésú Bács-Kiskunban pedig a legalacsonyabb a népsürüség.

2004 elején Dél-alföld lakosságának 48 százaléka férfi, 52 százaléka nő volt, a nôk száma több mint 66 ezer fôvel haladta meg a férfiakét. A férfiak magasabb halandóságának következményeként az elmúlt években a népességen belül folytatódott a nők arányának lassú emelkedése, jelenleg 1000 férfira 1102 nő jut.

A születések számának visszaesése és az átlagos élettartam meghosszabbodása következtében a népesség korösszetétele egyre kedvezőtlenebb: a gyermekkorúak részaránya folyamatosan csökken, miközben az idősebbeké nő. 1990-ben a régiós lakosságnak még 20 százaléka volt fiatalabb 15 évesnél, 2004 elején már csak 16 százaléka. Ezzel egyidőben a 64 éven felüliek aránya 14-ről 16 százalékra növekedett. Korösszetétel szempontjából a régión belül Bács-Kiskun megye van a legkedvezőbb helyzetben, itt arányaiban több fiatal él, mint a régió többi részén. Csongrádban a középkorosztály aránya nagyobb a régiós átlagnál, míg Békésben az idősebbeké. (7. táblázat) 
A népesség megoszlása fóbb korcsoportok szerint a Dél-alföldön (\%-ban)

\begin{tabular}{|c|c|c|c|c|c|c|}
\hline \multirow{2}{*}{ Korcsoport } & \multicolumn{3}{|c|}{ Férfi } & \multicolumn{3}{|c|}{ Nő } \\
\hline & 1990 & 2001 & 2004 & 1990 & 2001 & 2004 \\
\hline Gyermekkorú (0-14 éves) & 21,4 & 17,8 & 16,9 & 19,0 & 15,6 & 14,7 \\
\hline Fiatalabb felnőtt korú (15-39 éves) & 36,4 & 36,5 & 37,1 & 33,2 & 32,1 & 32,4 \\
\hline Idősebb felnőtt korú (40-64 éves) & 30,3 & 33,0 & 33,2 & 31,3 & 33,5 & 33,5 \\
\hline Időskorú (65 éves vagy idősebb) & 11,9 & 12,7 & 12,8 & 16,5 & 18,7 & 19,4 \\
\hline ÖSSZESEN & 100,0 & 100,0 & 100,0 & 100,0 & 100,0 & 100,0 \\
\hline
\end{tabular}

Forrás: Békés Megyei Területfejlesztési Tanács honlapja, Dél-alföldi helyzetelemzés

A régió lakossága az elmúlt években valamivel lassabban öregedett, mint az országé. Ezt a folyamatot jól mutatja az öregedési index ${ }^{25}$ változása: a Délalföldön e mutató 32-vel, az ország egészében pedig 34-gyel emelkedett 1990 óta. A régió lakossága ennek ellenére még mindig kissé öregebb, mint az országé, hiszen 2004-ben a régióban 100 gyermekre átlagosan 103 idős személy jutott, az ország egészében pedig 98. E mutató Közép-Magyarország (111) és Nyugat-Dunántúl (103) után a Dél-alföldön a legmagasabb. ${ }^{26}$

1990 és 2003 között a Dél-alföldi régió pozitív vándorlási nyereséget könyvelhetett el. Feltételezhetjük, hogy a kilencvenes évek vándorlási tendenciái a mai viszonyoktól eltérôen jellemezhetők: míg a korábbi évtizedeket a faluról városba áramlás jellemezte, azonban a folyamat az 1990-es évek közepén nemcsak, hogy megállt, de meg is fordult, s ma már a dél-alföldi falvak egy része növeli népességét (Ballószög, Helvécia, Lajosmizse, Algyő, Deszk, Domaszék, Röszke, Sándorfalva, Szatymaz). Leginkább a Kecskeméthez és a Szegedhez közeli települések növelték népességszámukat és viselkednek ma már sajátos elővárosi zónaként, ám feltételezhetjük, hogy a közeljövőben Baja, Békéscsaba, de Hódmezővásárhely és Kiskunhalas körül is számolhatunk a népesség szuburbanizációs jellegú kiáramlásával. Ugyanakkor megindult egyfajta

${ }^{25} \mathrm{Az}$ öregedési index a 64 éven felüli népesség 15 éven aluli népességhez viszonyított aránya.

${ }^{26}$ Forrás: Dél-alföldi Regionális Egészségfejlesztési Program Helyzetfelmérés, EM Csoport Kht. 
újratanyásodási folyamat is (Árpádhalom, Eperjes, Kardos, Kétsoprony, Tömörkény). A leginkább tanyás vidéknek a Kecskemét-Szeged vonaltól nyugatra elhelyezkedô homoki terület és a Szentes, Szarvas, Békéscsaba, Csongrád környéki rész számít.

A régió foglalkoztatottsági szintjéről elmondható, hogy 2000-ben Csongrád megye bírt a legmagasabb foglalkoztatottsági rátával ${ }^{27}$, 2003-ra változás állt be és Bács-Kiskun megye vette át a vezető szerepet (49\%), Csongrád (47\%) és Békés (44\%) megyék előtt.

A foglalkoztatásról szólva ki kell emelnünk, hogy mindhárom megye messze elmaradt az országos átlagtól a munkahelyteremtés szempontjából, míg országosan 46,7\%-ról 50\%-ra nőt, addig a Dél-alföldön 1996 és 2003 között csekély mértékben javult csak (46,6\%-ról 47\%-ra).

A költözés témájában elmondhatjuk, hogy amellett, hogy e szempontból nyilvánvalóan a fiatal pályakezdők a legmobilabbak, ugyanakkor több rétegú összetett módon, általában a várható munkajövedelem összege, az egyéb juttatások, a lakásszerzés és -fenntartás költségei, a lakókörnyezet rendezettsége és színvonala, valamint a családi és baráti kötődések alapján dönt egy esetleges költözésről. Idevonatkozó információink alapján úgy látjuk, a belföldi vándorlás kevésbé régiónként (természetesen nem hagyható figyelmen kívül Budapest hatása), ám inkább kistérségenként történik, ugyanakkor azonos módon befolyásolhatja azt az autópálya építésének hatása, továbbá a már említett szuburbanizáció. A területfejlesztési kutatók e kérdésben általában kiemelik, hogy „a Tiszától keletre és Bács-Kiskun dél-nyugati részén a fiatalok a lábukkal szavaznak". Az elvándorlási hajlandóságot Magyarország Európai Uniós csatlakozása kitágította és felerősítette. Fokozottan érvényes ez a munkaerőpiacon jól mobilizálható szakmák és az úgynevezett felsőfokú slágerdiplomák tulajdonosaira. A fiatalok költözésének tendenciáit és a költözési hajlandóságot, úgyis, mint az egyéni karrier- és életút-tervezés egy fontos szempontját, részelemét további kutatásokkal lehet feltárni.

A régióban számos felsőoktatási intézmény múködik [Szegedi Tudományegyetem (Szeged), SZTE Mezőgazdasági Kara (Hódmezővásárhely), Kecskeméti Főiskola (Kecskemét), Tessedik Sámuel Főiskola (Szarvas, Békéscsaba),

${ }^{27}$ Foglalkoztatottsági ráta alatt a foglalkoztatottak számának a munkaképes korúak (KSH: 15-74 éves lakosság) számához viszonyított arányát értjük. A DARFT kutatói regionális helyzetfelmérésükben kiemelik, hogy szerencsésebbnek tartanák, ha a 1564 éves lakosságot tekintenék a számítás alapjának, hasonlóan, mint az Európai Unióban általában. (www.del-alfold.hu) 
és a bajai Tanítóképző Főiskolai Kar], amik nagymértékben hatnak a fiatalok életére. A három intézmény hallgatóinak létszáma meghaladja a 30.000 főt. E sajátos életstíluscsoport (az egyetemisták-főiskolások) erős fogyasztói tömbként (és célközönségként) jelenik meg a régió gazdaságában. El kell mondanunk, hogy egy régió versenyképessége szempontjából nem csak a rendelkezésre álló munkaerő mennyisége, hanem annak minősége is fontos, tehát nem hagyható figyelmen kívül a Dél-alföldi régió bemutatásakor, hogy annak milyenek a foglalkoztatottak legmagasabb iskolai végzettsége szempontjából a paraméterei. (8. táblázat)

A népesség megoszlása föbb korcsoportok szerint a Dél-alföldön (\%-ban)

\begin{tabular}{|c|c|c|c|}
\hline & $\begin{array}{c}1000 \text { lakosra } \\
\text { jutó szja- } \\
\text { adózók száma } \\
(2003)\end{array}$ & $\begin{array}{l}\text { Egyetemet, főiskolát } \\
\text { végzettek a } 25 \text { évnél } \\
\text { idősebb népesség } \\
\text { arányában (\%) (2001) }\end{array}$ & $\begin{array}{l}\text { Egyetemet, fóiskolát vég- } \\
\text { zettek aránya a foglal koz- } \\
\text { tatottakon belül a régió } \\
\text { megyéiben }(\%)(2001)\end{array}$ \\
\hline Bács-Kiskun megye & 412 & 9 & 13,9 \\
\hline Békés megye & 420 & 8,1 & 14,0 \\
\hline Csongrád megye & 433 & 12,5 & 18,3 \\
\hline Dél-alföld & 421 & 9,8 & \\
\hline Magyarország & 428 & 12,6 & \\
\hline
\end{tabular}

Forrás: Békés Megyei Területfejlesztési Tanács honlapja, Dél-alföldi helyzetelemzés

A dél-alföldi viszonylatban igen fejlettnek minősített települések csoportja a legnagyobb, valamint a tradicionális közép- és kisvárosok körébe tartozik. Közöttük található Szeged, Békéscsaba, Gyula, Orosháza, Baja, Kalocsa, Kecskemét, Hódmezővásárhely, Szentes és Szarvas, amelyek a legmagasabb iskolai végzettséggel bíró települések, vagyis a Dél-alföld azon városai, ahol a társadalmi-gazdasági megújuló képesség a népesség iskolai végzettsége alapján valós és igen fontos alapadottságként vehetô figyelembe.

A területfejlesztési kutatók általában mindezek közül kiemelik Szegedet, mint pozitív hatását már a közvetlen környezetére is kiterjesztô, a jövőben az elővárosiasodó falvak gyưrújéből összefüggő, urbanizált teret építő várost. E tendencia az urbánus népesség és tevékenységek decentralizációja és a szuburbanizáció hatásaként nyer teret. 


\section{2. A dél-alföldi régió önkormányzatainak ifjúságpolitikája}

A mai magyar közigazgatási rendszerben a közszolgáltatások döntő többségének megszervezése az önkormányzati törvényben meghatározott kötelező, illetve vállalható feladatok, illetve a különbözó ágazati törvényekben lefektetett kötelező feladatok útján történik.

Az önkormányzati törvény a szabadon vállalható önkormányzati feladatok között nevesíti a gyermek és ifjúsági feladatokat. Jelenleg egyetlen ágazati törvény sem határozza meg pontosan a fenti feladat tartalmát.

A helyi önkormányzatokról szóló 1990. évi LXV. törvény számos lehetőséget kínál a gyermek és ifjúsági érdekek megjelenítésére, képviseletére és a települési önkormányzat munkájában ezek érvényesítésére.

Az önkormányzati törvény 8. \-ának (1) bekezdése előírja a települési önkormányzatoknak a gyermek és ifjúsági feladatokról való gondoskodást, 8. \ának (5) bekezdése pedig a helyi önkormányzatok kötelességeként fogalmazza meg, hogy együttműködnek a helyi civil szerveződésekkel, támogatják azok munkáját. A 63/A $\int$ n) pontja a fővárosi önkormányzat feladatkörébe utalja többek között az ifjúsági feladatokat. A 70/A \a) a megyei önkormányzat feladatkörébe utalja a gyermeki és ifjúsági jogok érvényesítésével kapcsolatos feladatokat.

Tekintettel a gyermek és ifjúsági feladatok meghatározásának hiányára, a készülő ifjúsági törvény központi eleme lesz az ifjúsággal kapcsolatos egyes önkormányzati közfeladatok meghatározása.

Az önkormányzat gyermek- és ifjúsági feladataival foglalkozók az egyik legszélesebb kapcsolati körben mozognak: az önkormányzati intézményrendszer legnagyobb szelete a közoktatás és a szociális ügyek. A közművelődési és a sportintézmények látogatói is nagyrészt gyermek vagy fiatal korúak, s talán az ő „szervezettségük” a legnagyobb az önkormányzat hatókörében működő civil szervezeteket tekintve is. A kifejezetten korosztályi civil szervezetek mellett ott állnak az ún. támogató szervezetek (egyesületek, alapítványok), s az egyházak, a felekezetek, de még a korosztálynak termelő vagy szolgáltató gazdasági társaságok is részei annak az összetett kapcsolatrendszernek, amelyben a település gyermek- és ifjúsági ügyei történnek. 
A település, a régió területén, s illetékességi körében (tanügyigazgatás, gyámügy, gyermek- és ifjúságvédelem, művelődés, sport stb.) az önkormányzat alapvető érdeke, hogy függetlenül a szakmai érvektől és megfontolásoktól, megszervezze azt a civil-társadalmi kontrollt, amely a gyermek- és ifjúsági korosztályok érdekérvényesítési törekvéseiből ered, s amely támogatója lehet az önkormányzat törekvéseinek is.

A települések döntő többségében azonban hiányzik a tagolt gyermek- és ifjúsági szervezeti, illetve támogatói struktúra, amely kellő társadalmi és szakmai legitimációt adna az önkormányzattal tárgyaló feleknek.

A dél-alföldi régióban végzett kutatás ${ }^{28}$ keretein belül a régióban található 254 települési önkormányzat közül 235 települési önkormányzat töltötte ki a kérdőívünket, amelyben rákérdeztünk az ifjúságpolitikai kérdésekre, az önkormányzat ifjúsággal kapcsolatos tevékenységeire, és szervezeti felépítésére. A minta eloszlását a következő táblázat mutatja. (9. táblázat)

A régió önkormányzatainak megoszlása

\begin{tabular}{|l|c|c|c|}
\hline & Bács-Kiskun & Békés & Csongrád \\
\hline Megyei jogú város & 1 & 1 & 2 \\
\hline 20 Efő fölötti város & 3 & 3 & 3 \\
\hline Város & 16 & 13 & 3 \\
\hline Község & 99 & 58 & 52 \\
\hline Összesen & 119 & 75 & 60 \\
\hline
\end{tabular}

A kutatási minta megoszlása

\begin{tabular}{|l|c|}
\hline Megyei jogú város & 4 \\
\hline Város & 41 \\
\hline Község & 190 \\
\hline Összesen & 235 \\
\hline
\end{tabular}

\footnotetext{
${ }^{28}$ A kutatás 2005. augusztus 5. és 17. között Bács-Kiskun, Békés és Csongrád megyei önkormányzatoknál zajlott. A kutatást az Európai Ifjúsági Kutató, Szervezetfejlesztő és Kommunikációs Központ végezte 18 kérdéscsoportból álló kérdőívvel. Kutatásvezető: Jancsák Csaba. $\mathrm{N}=235$. E helyütt csak a kutatás idevonatkozó adatainak rövid ismertetésére van lehetôségük.
} 


\subsection{Ifjúsági intézményrendszer}

Egy település ifjúságpolitikájában az első és legfontosabb kérdés, hogy a települési önkormányzaton belül van-e olyan bizottság, amelynek a feladata az ifjúsági ügyekkel való foglalkozás. A megkeresett településeknek csak a 20,9\%a rendelkezett olyan bizottsággal, amelynek feladata az ifjúsági ügyek koordinálása. Azonban a településtípust vizsgálva nagy különbségek találhatóak. A megyei jogú városok közül mindegyik rendelkezett ifjúsági bizottsággal. A városoknak a 43,9\%-a rendelkezett ifjúsági bizottsággal, a községeknek pedig csak 14,3\%-a.

Az önkormányzatok 38,7\%-a válaszolta azt, hogy ugyan nem múködik olyan bizottság, amelynek deklarált célja lenne ifjúsági ügyekkel való foglalkozás, de más bizottságok foglalkoznak az ifjúságot is érintő kérdésekkel. Az önkormányzatnak a 40,4\%-a pedig semmilyen más bizottsága sem foglalkozik ifjúsági ügyekkel. (18. grafikon)

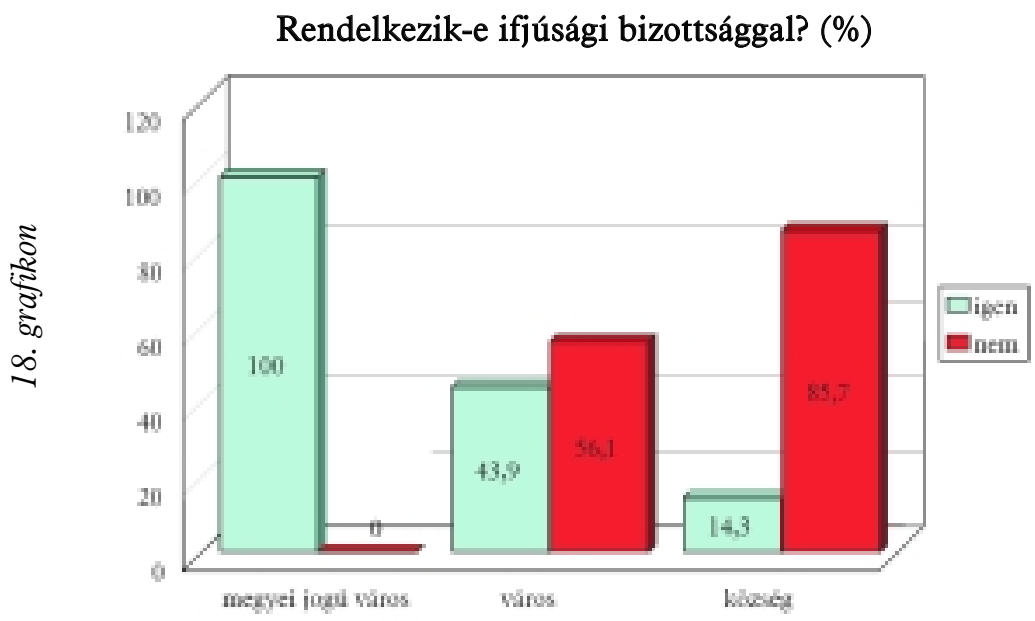

Azt azonban hozzá kell tenni, hogy sehol sem találtunk olyan bizottságot, amely kizárólag az ifjúsági ügyekkel foglalkozott volna. Leggyakrabban az ifjúsági és sport ügyeket bízták egy bizottságra, de gyakori volt, az oktatási, gyermek, egészségügyi és múvelődési bizottsággal történő összevonás. Az alábbi táblázat mutatja, hogy milyen bizottságokban fordulnak elő az ifjúsági ügyek. (10. táblázat) 


\begin{tabular}{|l|}
\hline \multicolumn{1}{|c|}{ A bizottság neve } \\
\hline Gyermek Ifjúsági és Sport Bizottság \\
\hline Ifjúsági és Sport Bizottság \\
\hline Ifjúsági, Egészségügyi és Sport Bizottság \\
\hline Ifjúsági, Sport, Kulturális és Oktatási Bizottság \\
\hline Ifjúsági, Sport, Kulturális és Szabadidó Bizottság \\
\hline Kulturális, Ifjúsági és Sport Bizottság \\
\hline Múvelődési, Ifjúsági és Sport Bizottság \\
\hline Oktatási és Ifjúsági Bizottság \\
\hline Oktatási, Ifjúsági és Sport Bizottság \\
\hline Oktatási, Ifjúsági, Múvelődési, Kisebbségi Bizottság \\
\hline Oktatási, Múvelódési, Ifjúsági és Sport Bizottság \\
\hline Oktatási, Kulturális, Sport és Ifjúsági Bizottság \\
\hline Szociális és Ifjúsági Bizottság \\
\hline Szociális és Ifjúságvédelmi Bizottság \\
\hline Szociális, Egészségügyi, Oktatási, Kulturális és Sport Bizottság \\
\hline Ügyrendi Bizottság \\
\hline
\end{tabular}

A nem kifejezetten ifjúsági bizottságok közül az alábbiak foglalkoznak ifjúsági ügyekkel. Itt is látható, hogy leggyakrabban a sport, egészségügyi, szociális, múvelődési, kulturális és oktatási bizottságok alá vannak beosztva az ifjúságot érintő ügyek. (11. táblázat)

A kutatás során rákérdeztünk arra is, hogy az önkormányzat foglalkoztate ifjúsági referenst. Csupán 36 önkormányzat (15,3\%) alkalmazott ilyen munkakörben embereket. De közülük is csak 17-an voltak fó állásban alkalmazva (47,2\%), 8-en részmunkaidőben (22,2\%), 11-en pedig egyéb jogviszonyban látták el a feladatukat (30,6\%). Szintén eltérések tapasztalhatóak a településtípus szerint. Míg a megyei jogú városok közül 75\%-ban volt ifjúsági referens, addig a városi önkormányzatok $41,5 \%$-a rendelkezett ifjúsági referenssel, a községi önkormányzatoknak csupán a 8,4\%-a.

Annak ellenére, hogy az önkormányzatok közül nem mindegyikben, múködik ifjúsági referens, vagy ifjúsági, vagy ifjúsági ügyeket is érintő bizottsága, az önkormányzatoknak a 87,2\%-a nyilatkozott úgy, hogy saját maga látja el az ifjúsági feladatokat. 9\%-uk önkormányzati társulás formájában látja el az ifjúsági feladatokat, 3,8\%-uk pedig egyéb formában. Természetesen itt is különbségek mutatkoznak településtípusok szerint, míg a megyei jogú váro- 
Ha nincs ifjúsági bizottság mely bizottság alá tartoznak az ifjúsági ügyek?

\begin{tabular}{|c|c|c|}
\hline & A bizottság neve & elemszám \\
\hline & Általános Bizottság & 1 \\
\hline & Egészségügyi és Sport Bizottság & 1 \\
\hline & Egészségügyi és Szociális Bizottság & 3 \\
\hline & Egészségügyi, Szociális és Ifjúságvédelmi Bizottság & 1 \\
\hline & Gazdasági, Kulturális, Egészségügyi és Sport Bizottság & 1 \\
\hline & Humánpolitikai Bizottság & 3 \\
\hline & Közjóléti Bizottság & 1 \\
\hline & Közmúvelődési Bizottság & 1 \\
\hline & Közmúvelődési és Sport Bizottság & 1 \\
\hline & Közmúvelődési, Oktatási és Sport Bizottság & 1 \\
\hline & Közoktatási és Közmúvelési Bizottság & 1 \\
\hline & Kulturális Bizottság & 4 \\
\hline & Kulturális és Oktatási Bizottság & 1 \\
\hline & Kulturális és Sport Bizottság & 2 \\
\hline & Kulturális, Közoktatási és Sport Bizottság & 1 \\
\hline & Kulturális, Oktatási és Sport Bizottság & 2 \\
\hline & Kulturális, Oktatási, Sport, és Faluszépítő Bizottság & 1 \\
\hline$F$ & Múvelődési Bizottság & 1 \\
\hline & Múvelődési és Közoktatási Bizottság & 1 \\
\hline & Múvelődési és Oktatási Bizottság & 1 \\
\hline & Múvelődési és Sport Bizottság & 3 \\
\hline & Múvelődési Kulturális Bizottság & 1 \\
\hline & Múvelődési, Közoktatási és Sport Bizottság & 1 \\
\hline & Múvelődési, Közoktatási és Sport Bizottság & 1 \\
\hline & Múvelődési, Oktatási és Sport Bizottság & 1 \\
\hline & Múvelődési, Sport és Idegenforgalmi Bizottság & 1 \\
\hline & Múvelődési, Sport, Szociális Bizottság & 1 \\
\hline & Múvelődési, Szociális és Sport Bizottság & 1 \\
\hline & Oktatási Bizottság & 4 \\
\hline & Oktatási és Közművelődési Bizottság & 1 \\
\hline & Oktatási és Kulturális Bizottság & 5 \\
\hline & Oktatási és Kulturális Bizottság & 1 \\
\hline & Oktatási és Múvelődési Bizottság & 2 \\
\hline
\end{tabular}




\begin{tabular}{|l|c|}
\hline Oktatási, Egészségügyi és Sport Bizottság & 2 \\
\hline Oktatási, Kulturális és Sport Bizottság & 4 \\
\hline Oktatási, Múvelódési és Sport Bizottság & 1 \\
\hline Oktatási, Múvelódési, Egészségügyi és Szociális Bizottság & 1 \\
\hline Oktatatási, Kulturális és Sport Bizottság & 1 \\
\hline Pénzügyi Bizottság & 3 \\
\hline Sport és Kulturális Bizottság & 1 \\
\hline Szociális Bizottság & 8 \\
\hline Szociális és Családügyi Bizottság & 1 \\
\hline Szociális és Egészségügyi Bizottság & 2 \\
\hline Szociális és Kulturális Bizottság & 2 \\
\hline Szociális, Egészségügyi és Kulturális Bizottság & 1 \\
\hline Szociális, Kulturális és Sport Bizottság & 1 \\
\hline Szociális, Kulturális és Ügyrendi Bizottság & 1 \\
\hline Szociálpolitikai és Egészségügyi Bizottság & 1 \\
\hline Településfejlesztési és Közszolgáltatási Bizottság & 1 \\
\hline Ügyrendi Bizottság & 7 \\
\hline Összesen & 90 \\
\hline
\end{tabular}

sok 75\%-a és a városok 97,6\%-a önállóan maguk látják el az ifjúsági feladatokat, addig ez az arány a községi önkormányzatoknál 85,2\%.

Nagyon kevés önkormányzat rendelkezik külön az ifjúsági ügyekre fordítható pénzalappal, (16 db) ez csupán az önkormányzatok 6,9\%-t jelenti. A legkisebb összeg, ami az ifjúsági alapban van. $300.000 \mathrm{Ft}$, a legmagasabb összeg pedig 8 millió forint volt.

A várakozásokkal ellentétben, azonban nem csak a megyei jogú városok, városok rendelkeztek külön ifjúsági alappal, hanem községek is, sőt a megyei jogú városok közül is csak az egyik rendelkezett külön ifjúsági pénzalappal. A mintában szereplő megyei jogú városoknak a háromnegyede rendelkezik ifjúsági alappal, a városok 14,6\%-a, a községeknek pedig a 3,7\%-a.

Az önkormányzatok 32,9\%-nak van ifjúsági ügyekre létrehozott közalapítványa. A mintában szereplő megyei jogú városok közül 75\% rendelkezik közalapítvánnyal, a városoknak 36,6\%-a alapított ifjúsági közalapítvány, a községeknél ez az arány $31,7 \%$. 


\subsection{Ifjúsági koncepció, cselekvési terv}

Az önkormányzatoknak a 12\%-a rendelkezik ifjúsági koncepcióval (28db), 77 tervezi, hogy készít majd egyet (32,8\%) és 128 önkormányzat (54,5\%) nem is tervezi az elkészítését. A megyei jogú városok közül ${ }^{29}(25 \%)$ rendelkezik elfogadott ifjúságpolitikai koncepcióval; a városoknak a 29,3\%-a és a községeknek az 7,9\%-a. Azok közül a megyei jogú városok közül, amelyek nem rendelkeznek ifjúsági koncepcióval, mindegyik tervezi a létrehozását, illetve már a Közgyúlés előtt van az anyag. A városoknak a 31,7\%-a egyáltalán nem tervezi az ifjúsági koncepció kialakítását, míg a községeknél ez az arány 60,5\%. (19. grafikon)

Van-e az önkormányzatnak ifjúsági koncepciója? (\%)

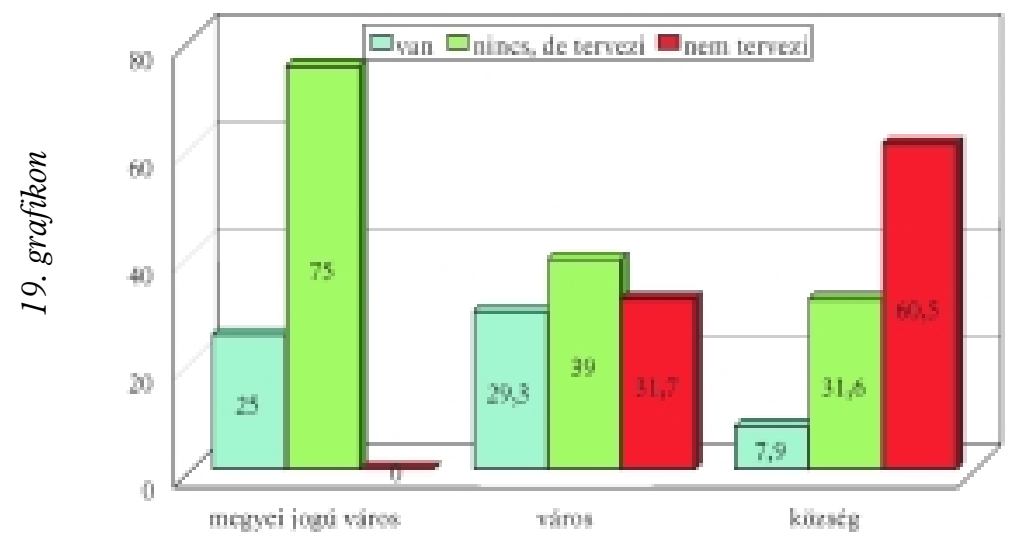

Az ifjúsági koncepció elkészítésénél - jelenleg készítése során - 37 önkormányzat vett igénybe valamilyen ifjúsági kutatást. Ez a 35,2\%-a azoknak az önkormányzatoknak, amelyek már kidolgozták, vagy tervezik kidolgozni az ifjúsági koncepciót. A kérdőívben azt kérdeztük meg, hogy az önkormányzat végzett-e kutatást, valakitől megrendelt-e kutatást, vagy a Mobilitás által végzett kutatást vették igénybe, az Ifjúság 2000 vagy Ifjúság 2004 kutatásokat. Egy olyan önkormányzat volt, amelyik 3 kutatást vett igénybe. (Ifjúság 2000, Ifjúság 2004, megrendelt kutatás) két olyan önkormányzat is volt, amelyik két

${ }^{29}$ Hódmezővásárhely: Ifjúsági és sportkoncepció (1997) 
kutatást vett figyelembe a koncepció kidolgozásánál, a többi önkormányzat pedig egy kutatást vett igénybe. Azok a városoknak - amelyek igénybe vettek valamilyen kutatást - a 68,8\%-a saját kutatást végzett, 16,7\%-a megbízott valakit, a kutatás elvégzésével, $11,1 \%$ vette igénybe a Mobilitás valamelyik kutatását, és 2 önkormányzat vette igénybe az Ifjúság 2000 kutatás adatait, és csak a $1 \mathrm{db}$ vette igénybe az Ifjúság 2004 adatait.

Azonban cselekvési terv nem készült minden esetben az ifjúsági koncepció kidolgozása után. A 28 ifjúsági koncepcióval rendelkező település közül csak $15(83,3 \%)$ települési önkormányzat készített az ifjúsági koncepcióhoz kötődő cselekvési tervet. A településeknek csak a 37\%-a tervezi azt, hogy készít cselekvési tervet is, szemben az ifjúsági koncepcióra vonatkozó 45,5\%-kal.

\subsection{Ifjúsági Önkormányzat}

A települések a 18,3\%-án múködik ifjúsági önkormányzat, de ezeket nem mindenhol vonják be az ifjúságot érintő kérdésekbe, csupán a 80,9\%-ukat.

Településtípusok szerint is különbségek találhatóak, míg a megyei jogú városok 75\%-ban múködik ifjúsági önkormányzat, addig a városok 29,3\%-ban, a községeknek pedig a 14,6\%-ban. A megyei jogú városokban és a városokban múködő ifjúsági önkormányzatokat minden esetben bevonják az ifjúságot érintő döntésekbe, addig a községekben ez az arány csak 71,9\%. (20. grafikon)

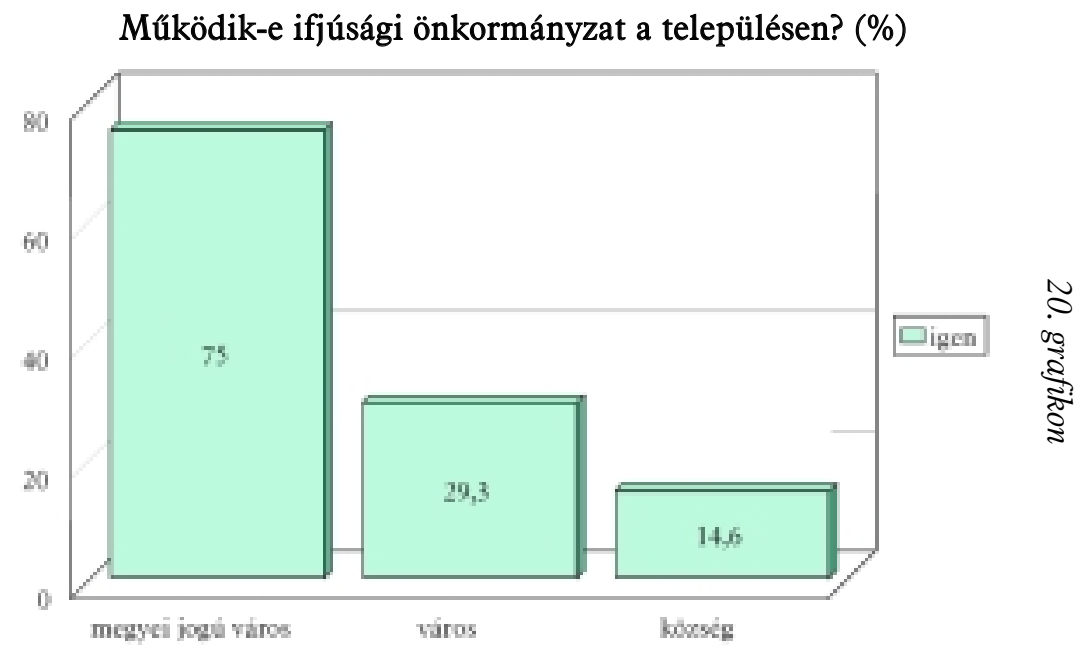


Az ifjúsági önkormányzatoknak 62,2\%-a kap pénzügyi támogatást az önkormányzatoktól, és 73,3\%-uk pedig természetbeni támogatást kap, amely leginkább az infrastrukturális hátteret jelenti.

\section{3. A régió civil szervezeti adottságai (régió-megye-település)}

A civil szervezetek általános vizsgálatakor ${ }^{30}$ azt látjuk, hogy a civil szervezetek száma és forrásfelvétele szempontjából Csongrád megye első a régióban.

Bács-Kiskun megyében aktív kistérség a bajai, kecskeméti, kiskunfélegyházi és kalocsai kistérség. Kevésbé aktív, illetve fejlesztésre szorul a bácsalmási és a jánoshalmi kistérség. Érdekes megjegyezni, hogy a KSH 2000-es adatai alapján ezekben a térségekben a civil szervezetek száma jóval a megyei átlag alatt mozog. Békésben a békéscsabai és az orosházi kistérség mutat kiugró teljesítményeket; míg a sarkadi kistérségben messze a legalacsonyabb a civil szervezetek száma. ${ }^{31}$

Csongrád megyében a megyei jogú városok mellett Szentes és térsége mutat jelentős civil és ifjúsági aktivitást. Kevésbé aktív a kisteleki kistérség, ahol a régió legkevesebb civil szervezetét találjuk ${ }^{32}$; a csongrádi és a mórahalmi. Bár ez utóbbiban 87 civil szervezet van, a terület forrásmegkötő és felhasználó képessége nagyon erős. Érdekesség Csongrád megyével kapcsolatban, hogy bár a makói kistérségben 155 bejegyzett civil szervezet volt, mégis alacsony a pályázási kedv és csekély a forrásfelvétel mértéke. (12. táblázat)

\section{3. $1 \mathrm{Az}$ ifjúsági civil szervezetek (számosságuk, tevékenységük, kapcsolataik, lehetőségeik), illetve az ifjúságot segíto civil szervezetek: tevékenységük, kapcsolataik, lehetőségeik}

E két téma része annak a kutatási programnak, amely ez év tavaszán került kidolgozásra, és melyet a DKMT Eurorégió Ifjúsági Szövetsége, a Hálózat a Szabad Információért Alapítvány, valamint a Mobilitás Dél-alföldi Regioná-

\footnotetext{
${ }^{30} \mathrm{KSH}$ : Nonprofit szervezetek Magyarországon 2000

${ }^{31}$ uo.

${ }^{32}$ uo.
} 
A civil szervezetek regionális megoszlása (db)

(KSH civil szervezet / a DARISZI-hez 2004-ben pályázó civil szervezet)

\begin{tabular}{|c|c|c|c|}
\hline Bajai & $329 / 10$ & \multirow{10}{*}{$\begin{array}{c}\text { Bács-Kiskun megye: } \\
2140 / 62\end{array}$} & \multirow{23}{*}{$\begin{array}{c}\text { A Régió összesen: } \\
5743 / 220\end{array}$} \\
\hline Bácsalmási & $58 / 1$ & & \\
\hline Kalocsai & $206 / 2$ & & \\
\hline Kecskeméti & \begin{tabular}{|l|}
$759 / 20$ \\
\end{tabular} & & \\
\hline Kiskőrösi & $195 / 2$ & & \\
\hline Kiskunfélegyházi & $170 / 5$ & & \\
\hline Kiskunhalasi & $190 / 14$ & & \\
\hline Kiskunmajsai & $60 / 4$ & & \\
\hline Kunszentmiklósi & $112 / 2$ & & \\
\hline Jánoshalmi & $61 / 2$ & & \\
\hline Békéscsabai & $898 / 13$ & \multirow{6}{*}{$\begin{array}{c}\text { Békés megye: } \\
1732 \text { / } 34\end{array}$} & \\
\hline Mezőkovácsházi & $142 / 5$ & & \\
\hline Orosházai & $237 / 4$ & & \\
\hline Sarkadi & $90 / 4$ & & \\
\hline Szarvasi & $201 / 4$ & & \\
\hline Szeghalmi & $164 / 4$ & & \\
\hline Csongrádi & $76 / 3$ & \multirow{7}{*}{$\begin{array}{c}\text { Csongrád megye: } \\
1871 / 108\end{array}$} & \\
\hline Hódmezővásárhelyi & $278 / 21$ & & \\
\hline Kisteleki & $51 / 3$ & & \\
\hline Makói & $155 / 6$ & & \\
\hline Mórahalmi & $87 / 3$ & & \\
\hline Szegedi & $1062 / 65$ & & \\
\hline Szentesi & $162 / 7$ & & \\
\hline
\end{tabular}

Forrás: KSH 2000, DARISZI

lis Ifjúsági Szolgáltató Iroda kezdeményezett és az Európai Ifjúsági Kutató-, Szervezetfejlesztő és Kommunikációs Központ végez. A kérdôíves adatfelvétel 600 civil szervezetnél (23 kérdéscsoportból álló standardizált kérdőívvel) folyik, majd interjúk és fókuszcsoportos beszélgetések következnek. A kutatási program első fázisának a kérdőíves szakasza szeptember 25-én zárult.

Most csak arra vállalkozhatunk, hogy a rendelkezésünkre álló forrásokból (a szintén e nyáron folyó Dél-alföldi Önkormányzatokat kutató vizsgálatunkból) röviden kiemeljünk néhány dolgot. (21. grafikon) 


\section{Az önkormányzati kutatási minta megoszlása (\%)}

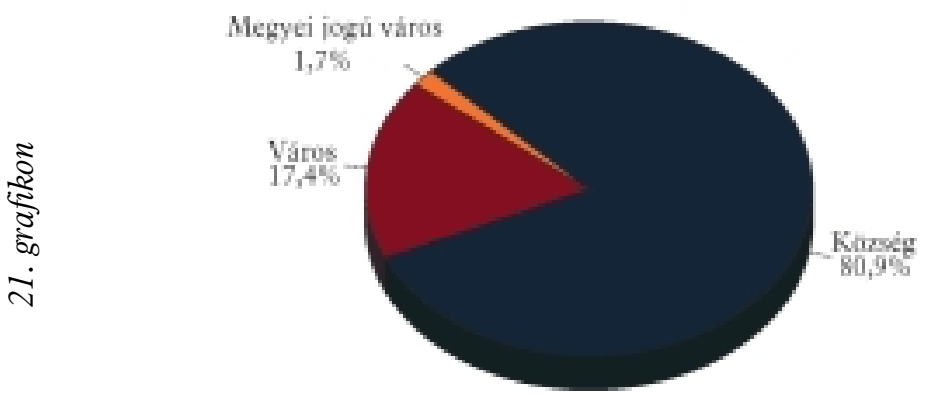

EIKKA 2005, $\mathrm{N}=235$

A minta megoszlásáról el kell mondjuk még, hogy a vizsgált településeken (235) összesen 1.303.866 fő él, melyek közül 0-14 éves gyermek összesen 688.224 fó és 14-29 éves fiatal pedig 217.926 fó.

Kutatásunkban a válaszadóktól megkérdeztük az adott önkormányzat illetékességi területén múködő gyermek- és ifjúsági ügyekkel foglalkozó (nem politikai) - nonprofit szervezetek száma, tehát ezek azok az adatok, amiket a települési önkormányzat tud, mely természetesen nem feltétlenül azonos a bírósági nyilvántartásban szereplő ilyen szervezetek számával. ${ }^{33} \mathrm{Mi}$ azonban arra voltunk kíváncsiak, hogy az önkormányzat mit tud a szektorról. A válaszadó településeken (190) összesen 1486 ifjúsági szervezetről tud az önkormányzata. Nem megyei jogú városokban 34 válaszadó összesen 194 szervezetről jelezte, hogy önkormányzat illetékességi területén múködő gyermek- és ifjúsági ügyekkel foglalkozó (nem politikai) nonprofit szervezet. A községek esetében pedig 157 válaszadó 267 ilyen szervezetet említett.

Ki kell emeljük, hogy a válaszadók szerint 0 gyermek és ifjúsági nonprofit szervezet van 47 községben és 3 városban (Mindszent, Kerekegyháza, Szabadszállás). Békésszentandráson és Kondoroson (községek) 8 szervezetrőll tettek említést, ami azonos a kecskeméti (megyeszékhely) illetve a csorvási és a gyomaendrődi (városok) önkormányzat által szolgáltatott adattal.

${ }^{33}$ A Dél-alföldi régióban 2000-ben 3.581.892 órát dolgoztak a civil szervezetekben az önkéntesek, ezzel mintegy 179,67 milliárd forint értékű munkát végeztek. Forrás: A nonprofit szervezetek önkéntes segítoinek fobb mutatói megyék és régiók szerint, Nonprofit, 2000. 168 
Az önkormányzat által szolgáltatott adatok alapján aktívnak mondható ifjúsági civil élet van a községek között Kondoroson és Békésszentandráson (8 szervezet), Ásotthalmon, Dunapatajon, Mártélyon, Földeákon (7 szervezet), Dusnokon, Szeremlén, Szegváron, Kétegyházán (6 szervezet), illetve Sarkad, Kaszaper, Lőkösháza, Zákányszék és Baks községekben (5 szervezet). A városok tekintetében az önkormányzat Szentes (30), Baja (27), Szarvas (27) és Makó (23) alkotja a civil ifjúsági szervezetek száma szerinti első csoport. (22., 23. grafikon)

Milyen önkormányzati intézmények, létesítmények szolgálják a gyermekek és a fiatalok szabadidó eltöltését (emlitések száma)

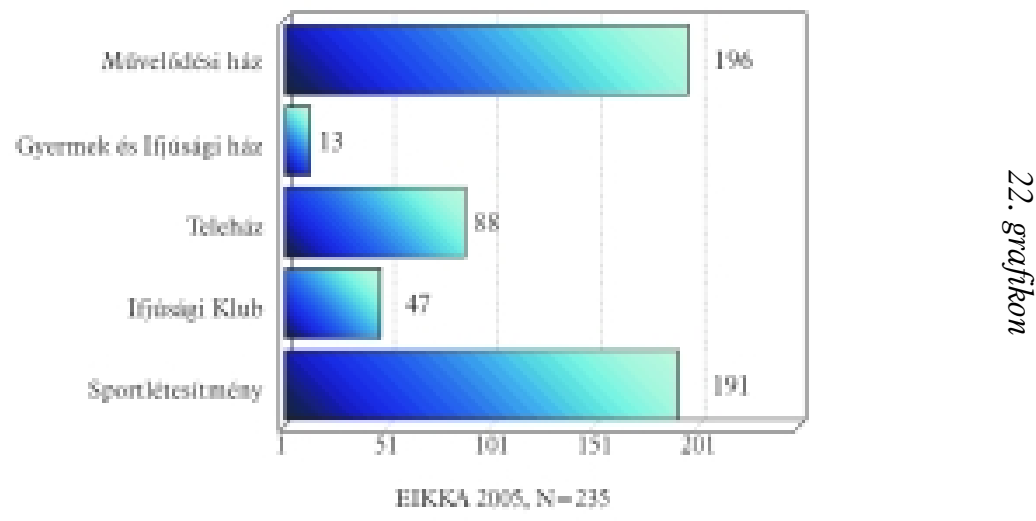

Milyen önkormányzati intézmények, létesítmények szolgálják a gyermekek és a fiatalok szabadidó eltöltését? (Az intézmények százalékos megoszlása)

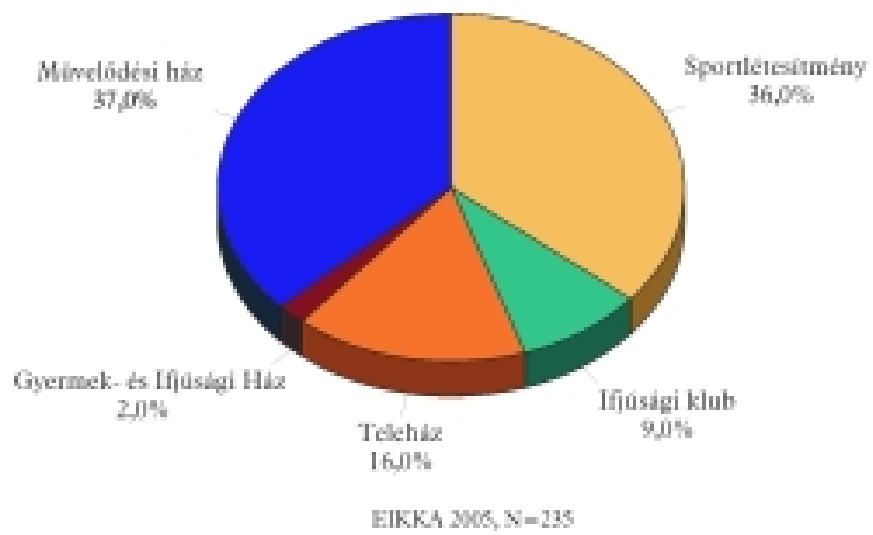

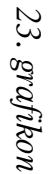


A fenti két grafikont áttekintve azt láthatjuk, hogy a régióban a fiatalok számára nem áll teljes körben rendelkezésre ifjúsági házak és ifjúsági klubok hálózata. Nem győzzük hangsúlyozni, hogy ez igen fontos kérdés, mert a szabadidő kihasználásának megtanulása és gyakorlása a személyes elégedettség központi kérdése, és éppen ezért azon a fiatalok, akiknek a fentiek szerint nem jut ki változatos szabadidős életstílus, később felnőttként sem tudják kielégítően eltölteni szabadidejüket. Az önkormányzatoknak a művelődési házak és sportlétesítmények fenntartásában kimerül a fiatalokat (is) célközönségükként fogadó intézmények köre.

A Családsegítő központok és gyermekjóléti szolgálatok szempontjából elmondhatjuk, hogy a válaszadó településeknek 27 százalékában nincs ilyen intézmény. ${ }^{34} \mathrm{Ki}$ kell azonban emelnünk, hogy a gyermekjóléti szolgálat, illetve a családsegító központ hiánya speciálisan a községek kérdésköre, ugyanis e halmazba (azon települések, ahol nincs ilyen intézmény) egy kivételtől eltekintve kizárólag községek tartoznak. Kalocsán, amely 10.001-20.000 fő közötti város, az önkormányzat információi szerint nincs gyermekjóléti szolgálat vagy önálló családsegítő központ. A továbbiakban elmondható, hogy az 5000 fó alatti községeknél (176 db) 59-ben nincs ilyen intézmény. Az 5001-10.000fó közötti lakossal bíró községeknél ( $7 \mathrm{db}$ ) egyedül Tiszaalpáron nincs gyermekjólléti szolgálat vagy önálló családsegítő intézmény. (24. grafikon)

\section{Múködik-e önállócsaládsegítő központ, vagy gyermekjólétszolgálat a településen} (A válaszadók százalékos megoszlása)

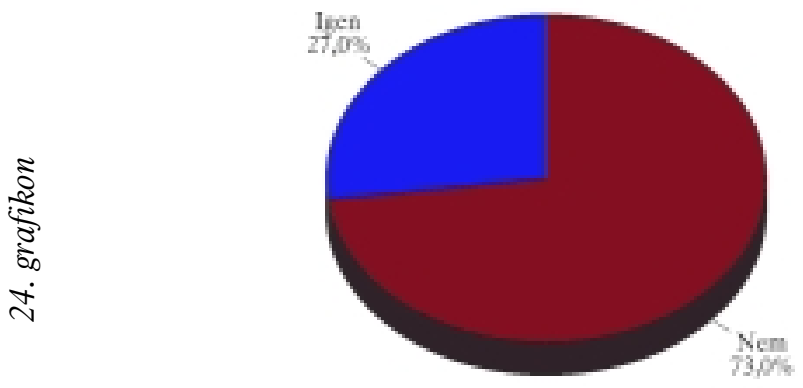

EIKKA $2000, \mathrm{~N}=235$

${ }^{34} \mathrm{Az}$ 1997. évi XXXI. törvény a gyermekek védelméről és a gyámügyi igazgatásról 40. \(1) pontja kimondja: „A települési önkormányzat a 39. \-ban meghatározott gyermekjóléti szolgáltatás szervezését, irányítását és összehangolását gyermekjóléti szolgálat múköodtetésével vagy családsegítő szolgálat keretében, illetve a külön jogszabályban meghatározott képesítési előírásoknak megfelelő személy foglalkoztatásával biztosítja.” 
Kutatásunkban arra is kíváncsiak voltunk, hogy a dél-alföldi települési önkormányzatok milyen jellegú támogatásokkal segítik a helyi ifjúsági szervezetek munkáját. 61 önkormányzat jelezte, hogy múködési költségekre való pályázatok kírásával támogatja az ifjúsági szervezeteket, 63 válaszadó szerint projektfinanszírozással történik a támogatás. Mindösszesen 81 önkormányzat jelezte, hogy rendszeres támogatás nyújt az ifjúsági szervezeteknek. Ezek százalékos megoszlását mutatja a következő grafikon. (25. grafikon)

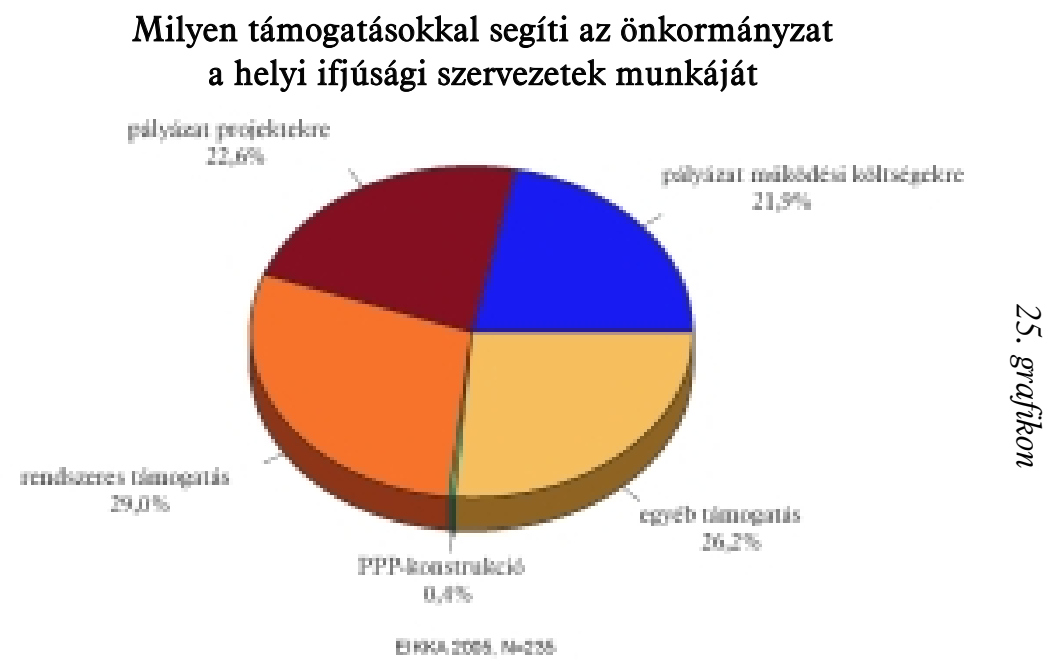

\section{4. A régió forrásfelvétele az ifjúsági munka területén 2000-2004}

\subsection{Ifjúság 2000-2006 Program}

Az Európai Unió tagállamai közösen hozták létre az Ifjúság 2000-2006 közösségi akcióprogramot, amely a jogi keretet adja az ifjúságnak szóló nem formális oktatási programok támogatásához. A program nem csupán a fiatalok saját projektjeit támogatja, hanem segíteni szeretne mindazoknak a szakembereknek is, akik fiatalokkal foglalkoznak valamilyen iskolán kívüli program megvalósításában. 


\section{Nemzetközi Programok Tanácsa}

Az Európai Unió nemzetközi ifjúsági programokra előirányzott kereteinek pályázati úton történő szétosztásáról, a felhasználás irányelveiről, az éves nemzeti prioritásokról a Nemzetközi Programok Tanácsa (NPT) dönt. A Tanács elnöke a Miniszter képviselője. Az NPT az Európai Bizottság ifjúsági programjára beérkező pályázatok elbírálását végzi, a Tanács titkára által előterjesztett értékelések figyelembe vételével. A támogatások odaítéléséről a Miniszter dönt.

A Tanács múködését a 13/2002. (X.11) számú GYISM határozat, és saját ügyrendje szabályozza. A titkársági feladatokat a Mobilitás Képzési és Kutatási Igazgatósága látja el. (forrás: www.mobilitas.hu)

A Program keretében nemzetközi ifjúsági cserék, ifjúsági találkozók, Fejlesztő Projektek, leginkább helyi szintű Ifjúsági Kezdeményezések megvalósítására, Európai Önkéntes Szolgálatban való részvételre van lehetôség. A program nem kizárólag anyagi támogatásokat nyújt, hanem képzési, információs, szakmai, módszertani szolgáltatásokat is. A legutóbbi időszak statisztikája a következőképpen néz ki a program dél-alföldi vetületéről. (13. táblázat)

Az Ifjúság 2000-2006 Program pályázatai a legutóbbi időszakban

\begin{tabular}{|c|c|c|c|c|c|}
\hline Időpont & $\begin{array}{c}\text { Beadott } \\
\text { pályázatok } \\
\text { száma }\end{array}$ & $\begin{array}{c}\text { Támogatott } \\
\text { pályázatok } \\
\text { száma }\end{array}$ & $\begin{array}{c}\text { A DARISZI } \\
\text { által } \\
\text { figyelemmel } \\
\text { kísért }\end{array}$ & $\begin{array}{c}\text { A DARISZI } \\
\text { által } \\
\text { figyelemmel } \\
\text { kísértek közül } \\
\text { nyertes } \\
\text { pályázatok }\end{array}$ & $\begin{array}{c}\text { A DARISZI } \\
\text { által } \\
\text { figyelemmel } \\
\text { kísértek közül } \\
\text { nem nyertes } \\
\text { pályázatok }\end{array}$ \\
\hline 2004.02 .01 & 16 & 9 & 0 & - & - \\
\hline 2004.04 .01 & 16 & 5 & 0 & - & - \\
\hline 2004.06 .01 & 12 & 5 & 5 & 4 & 1 \\
\hline 2004.09 .01 & 9 & 9 & 5 & 5 & 0 \\
\hline 2004.11 .01 & 21 & 7 & 6 & 3 & 3 \\
\hline 2005.02 .01 & 24 & 12 & 15 & 10 & 5 \\
\hline 2005.04 .01 & 26 & 16 & 13 & 9 & 4 \\
\hline 2005.06 .01 & 9 & 5 & 7 & 5 & 2 \\
\hline
\end{tabular}

Forrás: DARISZI 
$\mathrm{Az}$ összesített statisztika kibontása után a következüket mondhatjuk el. A fenti időszak alatt a pályázatok összesen 380.200 Euró-t $(95.050 .000 \mathrm{Ft}$ ) nyertek. A programra mindösszesen 133 pályázó jelentkezett. A pályázók közül, 37 településről 69 lett nyertes.

A leadott pályázatok (133) közül összesen 63 érkezett valamely megyeszékhelyről (Békéscsaba: 13; Kecskemét: 15; Szeged: 35), s közülük 31 nyert (Békéscsaba: 10; Kecskemét: 8; Szeged: 23). A nem megyeszékhely települések pályázati megoszlása 70 (beadott), 38 (nyert). A nyertes pályázók fele tehát a három megyeszékhelyrôl származott.

A DARISZI a pályázatok során az információadástól (információs napok), képzések szervezésén, és személyes tanácsadáson keresztül, a partnerkeresésben való segítségnyújtásig látott el feladatokat. A nyertes pályázatok 55\%ának volt valamilyen szintû kapcsolata a DARISZI-vel. (26. grafikon)

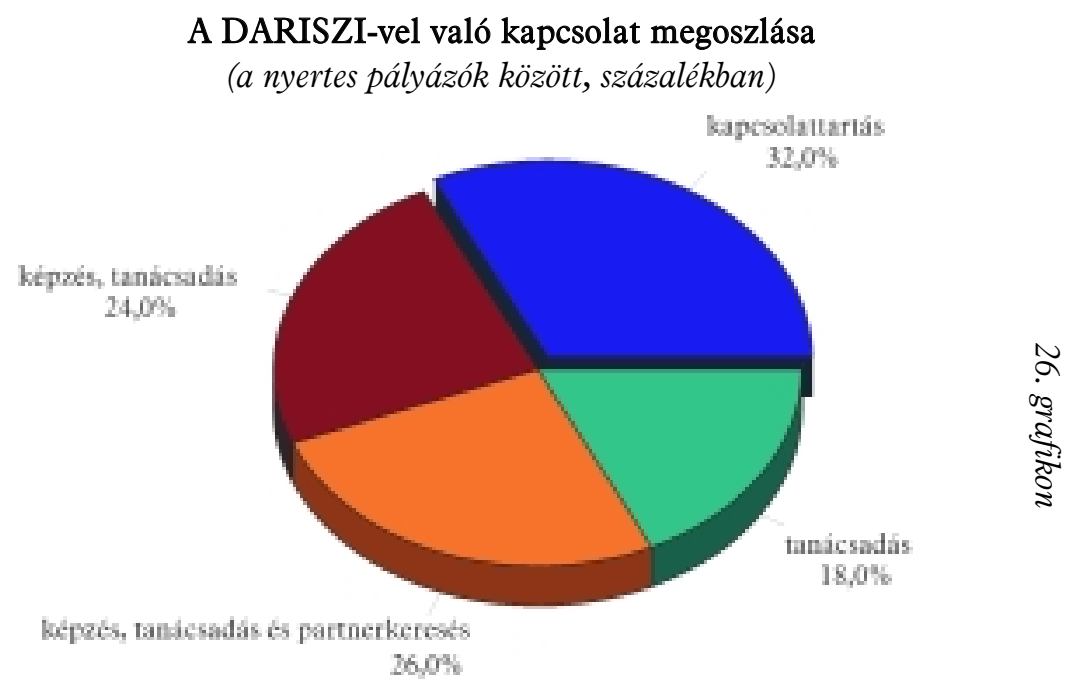

EIKKA 2005, Ferris DARIs]

A regionális irodával kapcsolatba került nyertes pályázók összesen 226.068 Euró-t nyertek. Az egy nyertes pályázóra (69 db) eső átlag Euró 5510 (1.377.000 Ft). Elmondható az is, hogy az iroda szolgáltatásait igénybe vevő pályázók átlagban nagyobb összeget nyertek (5.949: 4.972 Euró; $1.487 .250: 1.243 .000 \mathrm{Ft})$, amiből a DARISZI fejlesztő tevékenységnek minőségére következtethetünk. 
Amikor az Ifjúság 2000-2006 Program 2004 és 2005. évi pályázatainak időbeli sorait vizsgáljuk, akkor azt kell mondanunk, hogy lanyhább a pályázói aktivitás szeptember (2004) és július (2005) hónapokban, ilyenkor kevesebb, mint a felére esik vissza. A többi (2004. évi 4 db és 2005. évi $2 \mathrm{db}$ ) pályázati forduló alatt pedig kiegyenlített.

\subsection{GYISM, ICSSZEM, GYIA, RIT}

\section{Minisztérium}

Az ifjúsági korosztállyal összefüggő kormányzati tevékenységek koordinálásáért 1999-től az Ifjúsági és Sportminisztérium volt felelős. A miniszter feladatés hatáskörét a 113/1999. (VII. 16.) Kormányrendelet szabályozta. Az Ifjúsági és Sportminisztérium 2002-ben Gyermek-, Ifjúsági és Sportminisztérium néven, kibővült felelősségi körrel lett felelős a kormányzat gyermek és ifjúsági korosztállyal összefüggő tevékenységének koordinálásáért. A kibővült feladatés hatáskört a 157/2002. (VII. 11.) Kormányrendelet szabályozta. 2004 őszén megalakult az Ifjúsági, Családügyi, Szociális és Esélyegyenlőségi Minisztérium. A minisztérium az ifjúsági, szociális, családügyi és esélyegyenlőségi miniszter számára a Magyar Köztársaság Alkotmányáról szóló 1949. évi XX. törvényben és más vonatkozó jogszabályokban meghatározott feladat- és hatáskör gyakorlásához szükséges döntés-elókészítő, koordináló, végrehajtási és ellenőrzési feladatokat végzi. (forrás: www.icsszem.hu)

\section{Gyermek és Ifjúsági Alapprogram Tanácsa}

1999-ben a Magyar Köztársaság akkori ifjúsági és sportminisztere a 2/1999. (IX.24.) ISM számú rendelettel átalakította a Gyermek és Ifjúsági Alapprogramot. A rendelet 12. \-ának értelmében az Alapprogram kezelője a MOBILITÁS lett, evvel összefüggó feladatainak tekintetében a MOBILITÁS a Gyermek és Ifjúsági Alapprogram Titkárságának jogutódja. A Pályázati Igazgatóság vezetóje egyben a GYIA Tanács titkára.

A GYIA kereteiből a rendelet 2.』 (2) bekezdésében hivatkozott 1995. évi LXIV tv. 4. \-ában meghatározott célokat lehet támogatni. A támogatások elosztása a rendelet $2 \$$ (3) bekezdésében foglaltakkal összhangban, döntően- pá- 
lyázati rendszer keretében történik, az országos hatáskörú pályázatokat a GYIA Tanács (az éves keretösszeg kb. 20\%-a), a regionális hatáskörú pályázatokat a Regionális Ifjúsági Tanácsok írják ki (az éves keretösszeg kb. 70\%-a). 1995. évi LXIV. törvény 4.\$ (1)

4.S (1) Az Alap bevételi forrásaiból a következő célokat lehet támogatni:

A gyermekek testi, lelki, szellemi fejlődését segítő programokat, azon belül különösen:

- a gyermekek egészséges szabadidő eltöltésével kapcsolatos tevékenységeket,

- a gyermekek iskolán kívüli nevelésével összefüggő tevékenységeket,

- a gyermekek testi és lelki egészségét veszélyeztető jelenségek elleni fellépéssel kapcsolatos kezdeményezéseket,

- a honismereti, a helyismeretet elősegítő, a haza szeretetére nevelő programokat,

- természeti és épített környezet megóvását, védelmét segítő programokat, az ifjúság közösségi kezdeményezéseit, saját szervezeteik és csoportjaik kezdeményezéseit és tevékenységét,

- az ifjúság érdekében tevékenykedő intézmények, nem-kormányzati szervezetek olyan programjait, amelyek építenek a részvételre, a demokratikus döntéshozatalra, az együttmúköóésre,

- a demokráciára neveléssel, a demokratikus múködés gyakorlásával és az állampolgári neveléssel kapcsolatos programokat és kezdeményezéseket,

- a fiatalok saját problémamegoldó képességének erősítését elősegítő programokat,

- az európai integrációs folyamatban való ifjúsági részvételt, valamint az európai kapcsolatok kiépítését segítő kezdeményezéseket,

- a kábítószer, az alkohol, a dohányzás és más egészségkárosító szerek fogyasztásának veszélyeivel kapcsolatos megelóző, figyelemfelhívó programokat,

- hátrányos helyzetben lévő gyermekek és fiatalok felzárkóztatását segítő programokat,

- az ifjúság társadalmi helyzetének változásait nyomon követni képes információs és elemző rendszer kiépítését és múködését. (forrás: www.mobilitas.hu) 


\section{Regionális Ifjúsági Tanácsok}

A regionális ifjúsági szolgáltató irodák mellett fontos ifjúságpolitikai feladattá vált Magyarországon a regionális szintú támogatási rendszer kiépítése, megerősítése. A kormányzati ifjúságpolitika 2000-től nem központosított módon, hanem a régióközpontokon keresztül kívánja ösztönözni és támogatni a regionális és települési szintû́ ifjúsági munkát. Ezen célok megvalósításáért jött létre a 7 regionális ifjúsági tanács. Ez azért fontos, mert így az igényfelmérés, a helyzetfeltárás, a problémák orvoslása, az új kezdeményezések megismerése közelebb került a döntést hozókhoz. Ez által a tanács a rendelkezésére álló forráskeretének felhasználási módját, a támogatandó célokat, a pályázati kategóriákat, a támogatottak körét önmaga határozhatja meg.

A Gyermek és Ifjúsági Alapprogram forrásalapiából a 7 regionális ifjúsági tanács differenciált módon jut továbbosztandó támogatási keretösszeghez (a GYIA forrásalapjának 70\%-a a 7 régió között osztódik fel). Különböző gazdasági és társadalmi mutatók alapján a hátrányos helyzetú régiók nagyobb támogatási összeghez jutnak, mint a fejlettebb, kedvezőbb helyzetben lévő régiók.

\subsection{A DARIT $^{35}$ helye és szerepe a Dél-alföldön}

A Dél-alföldi Regionális Ifjúsági Tanács által meghirdetett múködési, programés eszköztámogatási pályázatok jellegének megoszlását és egymáshoz viszonyított súlyát jól megfigyelhetjük a pályázati keretösszegek változásán. Múködési támogatásra 2,7 millió Ft-os, eszköztámogatásra 11,5 millió Ft-os és programfinanszírozásra 194,9 millió Ft-os keret kiosztása történt meg. A programfinanszírozási források változásait jól nyomon követhetjük az alábbi ábrán.

A DARIT az iroda indulásakor (2000-ben) hirdetett meg először és utoljára múködés-támogatási pályázatot. Kétszer (2002-ben, illetve 2003-ban) pedig eszköztámogatási pályázatot. A múködési és az eszközvásárlási pályázatok során a pályázók valamivel több, mint $1 / 3$-a nyert.

A múködési és az eszközvásárlási pályázati fordulók fejlesztő hatása kétséges, noha el kell ismernünk, hogy a régió elmaradottabb, forráshiányosabb te-

\footnotetext{
${ }^{35}$ A DARIT-pályázatokra vonatkozó szövegek az iroda munkatársainak közlései alapján keletkeztek, adatkérés és interjúkésztés technikájával, illetve múhelybeszélgetéseken, értekezleteken, tájékoztató napokon elhangzottak alapján. Segítségükért külön köszönet illeti Árvai Marát, Kökény Szabolcsot és Vincze Józsefet a RISZI munkatársait, illetve Döbör Andrást a RIT alelnökét és Dr. Balogh Ádámot a RIT elnökét.
} 
rületein pozitív hatást fejthet ki, ám az hosszú távon csekély, például az átlagban 82.000 forintot elnyert 33 szervezet esetében a múködési támogatás. A múködési pályázati kategória szükségtelenségének kérdését árnyaltabbá teszi a nemzeti Civil Alapprogram (NCA) létrejötte. ${ }^{36}$ (27. grafikon, 14. táblázat)

\section{A DARIT által programfinanszírozásrakiosztott keretek}

(millió forintban)

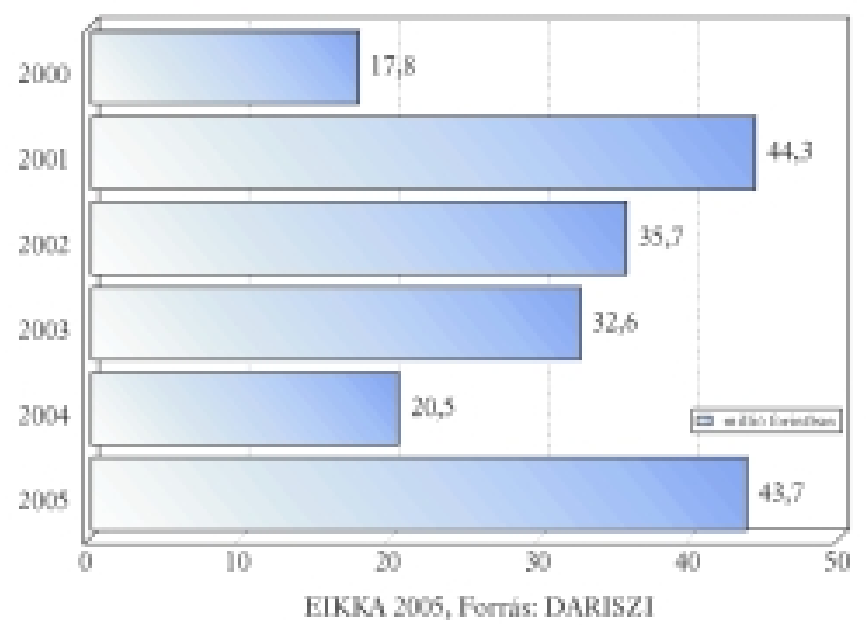

Az NCA 2004. évi statisztikája a dél-alföldi régióban hirdetett pályázatokról

\begin{tabular}{|c|c|c|c|c|c|c|c|}
\hline $\begin{array}{l}\text { Pályázati } \\
\text { fordulók }\end{array}$ & $\begin{array}{c}\text { Benyújtott } \\
\text { pályázatok } \\
\text { száma } \\
(\mathrm{db})\end{array}$ & $\begin{array}{c}\text { Támogatott } \\
\text { pályázatok } \\
\text { száma } \\
\text { (db) }\end{array}$ & $\begin{array}{c}\text { Támogatott } \\
\text { pályázatok } \\
\text { aránya } \\
(\%)\end{array}$ & $\begin{array}{c}\text { Igényelt } \\
\text { támogatások } \\
\text { összege } \\
\text { (millió Ft) }\end{array}$ & \begin{tabular}{|c} 
Odaítélt \\
támogatások \\
összege \\
(millió $\mathrm{Ft}$ )
\end{tabular} & $\begin{array}{l}\text { Megkötött } \\
\text { szerzódések } \\
\text { (db) }\end{array}$ & $\begin{array}{c}\text { Utalt } \\
\text { összeg } \\
\text { (millió Ft) }\end{array}$ \\
\hline 2004/I & 877 & 532 & $60,7 \%$ & 1010 & 300 & 529 & 298 \\
\hline 2004/II & 450 & 208 & $46,2 \%$ & nincs adat & 79 & 196 & 65 \\
\hline összesen & 1327 & 740 & - & - & 379 & 725 & 363 \\
\hline
\end{tabular}

Forrás: Magyar Államkincstár, www.nca.hu

${ }^{36}$ Az Országgyưlés 2003. június 23-án fogadta el a Nemzeti Civil Alapprogramról szóló 2003. évi L. törvényt, melynek fó célja a civil szervezetek pályázati támogatások útján történő támogatásával azok működésének megerősítése, a civil szektor fejlődésének elősegítése. Az első pályázatok 2004 májusában jelentek meg, és rendkívül nagy érdeklődést váltottak ki a pályázni jogosult szervezetek között. Az első évben több, mint 6 milliárd forint (24 millió Euro) vissza nem térítendő támogatás jutott el a sikeresen pályázó alapítványokhoz, egyesületekhez. (forrás: www.nca.hu) 
A DARIT közel ötezer, pontosan 4.747 pályázatból 1.819 projektet tudott támogatni, ez 38,3\%-os finanszírozási arányt jelent a beérkezett pályázatok számához viszonyítva. Az érvényes pályázatok számának arányában 51,2\%-os a támogatási mutató.

A 2003-as évig magas volt az érvénytelen pályázatok száma, ezen javított az a döntés, amely alapján 2004-től egyszeri hiánypótlásra nyílt lehetőségük a pályázóknak. Ez az új lehetőség jelentôs pozitív véleményt váltott ki a pályázók részéről, természetesen ez pályázatkezelői, bírálati szempontból újabb, plusz terhek megjelenését jelentette. A még meglévő, pl. 2004-ben $53 \mathrm{db}$, 2005-ben 76 db, érvénytelen pályázatok számát most már inkább a pályázásra nem jogosult kör pályázatait jelenti (általában figyelmetlenségből, kisebb mértékben „szándékosan” az adott pályázati felhívásban nem engedélyezett jogi státuszú pályázatbeadás okozza, és ebben az esetben továbbra sincs lehetőség hiánypótlásra). A bevezetett hiánypótlási lehetőség folytán a korábbi 30$40 \%$-os érvénytelenségi arány $10 \%$ körülire csökkent, pl. 2000-ben 44,2\%, 2001-ben 28,8\%,2002-ben 15,3\% (ami a legalacsonyabb szám volt a hiánypótlás bevezetése elött), 2003-ban újra 38,5\% volt, majd ezt követően 2004-ben 10,7\%, 2005-ben 10,8\% lett.

Természetesen az adott év igényelt összegeit, beérkezett pályázatok számát mindig befolyásolták az adott év kírási témakörei, illetve az adott felhívásnál meghatározott pályázói kör. Az évek alatt sok esetben kifogásolták az adott felhívásokból kizárt szervezetek, hogy ők miért maradtak ki a pályázatot beadhatók köréből. A Tanács döntéseit igazolják az így is jelentkező, kategóriánként is megjelenő többszörös igények, illetve bizonyos kírások meghatározott célcsoport számára születtek. Az igényelt több mint 1 milliárd Ft még több is lehetne, ha a kiírásokban nem lennének korlátozva, maximalizálva az egy szervezet által igényelhető összegek. Az évek alatt volt olyan kiírás, ahol pl. 40.000 Ft-nál (IFJ-GY-DA-03-I), vagy 75.000 Ft-nál (IFJ-GY-DA-04-D) nem lehetett többet kérni, a jellemző igényelhető összeg 150.000, 200.000, és 300.000 Ft között szóródott leginkább. A Tanács természetesen tisztában volt, illetve van azzal, hogy jóval nagyobb az igény minden évben a meghirdetett pályázati kiírásokra, de a központilag, különböző mutatók (gyermek és ifjúsági korosztály száma, gazdaság fejlettség stb.) alapján meghatározott véges, rendelkezésre álló, kiosztható régiós keret miatt cselekszik így (témakörök meghatározása, kategória keretösszegeinek meghatározása, pályázók körének meghatározása az adott felhívásokban, igényelhető összegek maximumának meghatározása, stb.). 
A nyertes pályázatok számát jelentős mértékben befolyásolta a keretösszeg mellet a Tanács adott évi támogatási elve (sok pályázatot támogatni, az igényelt összegnél jóval kevesebb összeggel vagy kevesebb pályázatot támogatni az igényelt összeghez közelítve), pl. a 2005-es évben (630-ból 407 támogatott, ami 64,6\%-s támogatási arány az érvényes pályázatok arányában) a sok pályázatot támogatni viszonylag kisebb összegekkel elv érvényesült a döntési folyamat során. A 2004-es évben viszont inkább a „kevesebb pályázatot támogatni, az igényelt összeghez közelítve" elv érvényesült, amit a támogatási arány is jól mutat (41,5\%, Nyertes pályázatok száma 184 db/Érvényes pályázatok száma $443 \mathrm{db})$.

A 2004-es év viszonylag alacsony keretösszege, illetve alacsony beérkezett pályázati száma azzal is magyarázható, hogy egyedül ebben az évben 2 központi pályázati kiírásnál a DARIT véleményezése, gyakorlatilag teljes kompetenciájú döntése alapján történt a beérkezett pályázatok elbírálása, a támogatási döntések meghozatala. A táboros kategóriában (régiós táboros kírás külön nem volt a központi keretösszeg nagysága miatt), csak a Dél-alföldi régióban, 43.700.000 Ft, az értékközpontú programok címú kategóriában 6.300.000 Ft került szétosztásra a Tanács javaslatai alapján.

A 2005-ben regionális szinten is bevezetett internetes pályázati rendszer (központi pályázatoknál 2004-ben került bevezetésre) lényegesen nem (kisebb mértékú csökkenés történt a korábbi évekhez képest) befolyásolta a beérkező pályázatok számát. A 2005-ös évben a kizárólag az internetes pályázati rendszerben beadható pályázati kategóriában volt megfigyelhető jelentősebb csökkenés. A későbbiekben érdemes lenne minden kategóriában biztosítani a „vegyes" (papíralapú és internet alapú) beadási módot, mert nagyon sok szervezet (főleg újak), itt tudják elsajátítani a pályázás alapjait, melyet később más kiíróknál is hasznosíthatnak, illetve nem mindenki rendelkezik megfelelő infrastruktúrával az internetes pályázatkészítéshez, és a választási lehetőséggel az esélyegyenlőség teljes mértékben megvalósulna.

Az évente megjelenő felhívásokban jól megfigyelhető egy tudatos folytonosság az újra ismétlődő ugyanazon kategóriák kiírásával (leginkább 2003-óta). Ennek okai többek között, hogy a régió szervezetei jónak találták az adott témájú kiírásokat, és elônyös abból a szempontból is, hogy rendszeresen ismerős űrlapokkal, követelményekkel találkozhattak az évek során. Az 5000 fó alatti és feletti települések programjainak a támogatására kiírt kategóriák esetén az esélyegyenlőség is kiemelten megvalósult az alacsonyabb lakosságszámú, „kevésbé profibb” pályázatkészítők és a gyakorlottabb, 5000 fő feletti la- 
kosságszámú települések pályázatíróinak a különválasztásával, és így mindig biztosítva volt kiosztható támogatási keretösszeg az 5000 fő alatti lakosságszámú települések gyermek és ifjúsági programjaira is.

\section{5. Regionális jellegzetességek, sajátosságok}

„A Dél-alföld jelenleg az ország egyik legkedvezőtlenebb demográfiai helyzettel jellemezhető régiója. Ebben meghatározó szerepe van az időskorúak kimondottan magas, a fiatalkorúak alacsony arányának, az évtizedek óta jellemző természetes fogyásnak, a válások gyakoriságának, az alacsony gyermekszámnak, a népesség kedvezőtlen egészségi állapotának, a rossz halálozási mutatóknak, az öngyilkosságok magas arányának. A problémákat tovább fokozza a hátrányos helyzetű határmenti (ország-, megyehatár) területeken és a belső perifériák kisebb falvaiban a kedvezőtlen aktivitási arány, a szociálisan veszélyeztetett társadalmi csoportok és a társadalom perifériájára szorulók számának növekedése és a régió egyes területein kimondottan magas munkanélküliségi ráta. Mindez figyelembe véve az állam által nyújtott ellátások (nyugdíj, munkanélküli ellátások, jövedelempótló támogatás, családi pótlék, stb.) színvonalát - a települési önkormányzatok által nem vagy csak rendkívül nehezen megoldható szociális és társadalmi feszültségeket okoz."”7

A Dél-alföldi régiót, mint Magyarország egyik legnagyobb kiterjedésú régióját sajátos sokszínúség jellemzi. E sokszínűség az ifjúsági szcenáriót is áthatja, mind az ifjúsági életmód és életforma, mind a személyes életkarrier-tervek és civil szervezetben kifejtett aktivitás, mind a jövőről való vélekedés és közéleti érdeklődés és motiváltság területén, ami meghatározza a régió különböző részein a fiatalok sebezhetőségét oktatásbeli, munkaerő-piaci és szabadidő téren egyaránt. A régióban 25 kistérség van, ami speciális feladatokat adhat a RISZI számára, ezen a téren nélkülözhetetlen a szoros együttmúködés a Teleházakkal, a Civil Házakkal és a kistérségi civil szervezetekkel.

A régiót a rendszerváltás utáni gazdasági és munkaerő-piaci átrendeződés erôteljesen megváltoztatta. Földrajzi (geopolitikai) elhelyezkedése szempontjából az „Európa Kapuja” szerep, a Budapesttól való távolság, azonosan esik latba, mint a Balkán (az olcsó munkaeró és ugyanakkor a folyamatos polgár-

${ }^{37}$ Csatári - Lengyel - Nagy - Nagy: A Dél-alföldi Régió Területfejlesztési koncepció felülvizsgálata. 2005 
háborús állapotok) közelsége. Mindezt bonyolítja, hogy a régió négy nagy városa (Szeged, Kecskemét, Békéscsaba, Hódmezóvásárhely) mellett a határok túloldalán hasonló méretű és fejlettségú települések (Temesvár, Szabadka, Újvidék, Arad, Zenta) vannak. A régiót egy sajátos gazdasági egységként értelmezni ma még nem lehet, ám a nemzetközi gazdaság napjainkban is már jelentôsen befolyásolja a magyarországi fiatalok munkaerô-piaci lehetőségeit.

A hármashatár (Triplex Régió, DKMT Eurorégió) az ifjúsági szervezetek kapcsolati hálózatát nemzetközi együttmúködésben erőteljesen meghatározza, amit árnyal az, hogy a két szomszédos állam közül egy az EU-hoz csatlakozó státuszban van, a másik pedig még távol áll a szándékától. A régiót ugyanakkor a határokon átívelő magyar-magyar kapcsolatok is erőteljesen jellemzik (a földrajzi értelemben vett Dél-alföld, Temesköz, Bácska, Tiszamente).

A régiónak sajátja, amit modern kifejezéssel multikulturalitásnak, más szavakkal a nemzetiségi kultúrák békés, elfogadó egymás mellett élésének és szimbiotikus egymásra hatásának nevezhetünk. A régió nemzetiségeinek történelme, boldog időszakai és tragédiái elválaszthatatlanul összeforrottak. A régiót alkotó számos kisebbség közül a román, a szerb és a szlovák a legnagyobb. E tényezők a fiatalok kulturális hagyományait, gyökereit meghatározzák, ugyanakkor színesítik a régió kulturális életét és a civil szervezetek alkotta palettát.

A régióban számos felsőoktatási intézmény múködik [Szegedi Tudományegyetem (Szeged), SZTE Mezőgazdasági Kara (Hódmezővásárhely), Kecskeméti Főiskola (Kecskemét), Tessedik Sámuel Főiskola (Szarvas, Békéscsaba), PTE Tanítóképző Fơiskolai Kar (Baja)], amik nagymértékben hatnak a fiatalok életére. E sajátos életstíluscsoport (az egyetemisták-fóiskolások) erős fogyasztói tömbként (és célközönségként) jelenik meg a régió gazdaságában. 


\section{Összegzés}

- A legfontosabb megállapítani, hogy a tanuló fiatalok aránya növekedett a régióban. Ez a tény kihatással van a többi vizsgált dimenzióra is. Ebből következik, hogy csökkent az aktív, dolgozó fiatalok aránya és növekedett a tanuló fiatalok aránya. Általánosságban elmondható, hogy a fiatalok helyzete rosszabbodott, mert anyagilag és a lakáshelyzet tekintetében rosszabb helyzetben vannak, mint négy évvel ezelőtt. Ezt tetézi még a növekvő munkanélküliség is. A lakáshelyzetben bekövetkezett változás mutatja, hogy a fiataloknak egyre nehezebb a lakáshoz jutás, azonban a tanuló fiatalok arányának növekedése is előidézhette a változásokat. Főleg a felsőfokú tanulmányok folytatásához sok esetben el kell költözni egy másik városba, ez magyarázhatja azt, hogy csökkent a lakással rendelkező és a szülőknél lakó fiatalok aránya is.

- A fiatalok nem rendelkeznek több szabadidővel annak ellenére, hogy a tanuló fiatalok aránya növekedett. Ez azt mutatja, hogy olyan versenyhelyzet alakult ki az oktatásban, és a munkaerőpiacon, amely megköveteli, hogy a formalizált oktatási rendszeren kívül is képezzék magukat a fiatalok, ezt pedig a szabadidejükben teszik meg.

- Az objektív mutatók alapján (anyagi helyzet, lakáshelyzet, munkaeró-piaci státusz) megállapítható, hogy romlott a fiatalok helyzete, azonban a fiatalok jövőképén ez nem látszik meg. Sokkal optimistábbak akár az ország gazdasági helyzetét tekintve, akár a saját jövőjüket tekintve, mint négy évvel ezelőtt voltak. Ennek egyik magyarázata lehet, a tanuló fiatalok arányának a növekedése, akik még bizalommal tekintenek a jövőbe.

- A szektort megcélzó pályázatokkal kapcsolatos tapasztalok alapján öszszességében elmondható, hogy kiemelt igény jelentkezik a programfinanszírozásra, a tárgyieszköz-fejlesztésre és a speciális programokra, például táboros témakörökben. A legnagyobb igény e célokkal kapcsolatban mutatkozott és valószínúleg fog is mutatkozni a gyermek és ifjúsági korosztállyal foglalkozó szervezetek részéről.

- A régióban múködő nonprofit szektort vizsgálva megállapítható, hogy a civil szervezetek többsége elszigetelten múködik, az együttmúködések, a települési/kerületi, kistérségi és regionális szintú érdekképviselet még nagyon gyenge alapokon áll. Egyes településeken az önkormányzat vezetôsége azonban már belátta, hogy a szúkös források miatt nem marad más lehetőség, mint az ifjúságügyek „kihelyezése” a településen múködő civil ifjúsági szer- 
vezetek hatáskörébe. Sajnos ez is csak ritkán látszik megoldani az ifjúsággal kapcsolatos teendőket, hiszen ma hazánkban jellemzően bizonytalan pénzügyi helyzetben van a nonprofit szektor. A múködési költségeket és a programok szervezéséhez szükséges kiadásokat többnyire pályázati forrásokból és adományokból tudják finanszírozni, ami kiszolgáltatottá teszi a szervezeteket és elbizonytalanítja múködésüket.

- Az önkormányzatok esetében is a fó problémát az anyagiak hiánya jelenti. Bár a szemléletmód határozott javulást mutat és egyre több település tekint az ifjúságra, mint erőforrásra, a rendelkezésükre álló lehetőségek meglehetősen szúkösek. Ahhoz, hogy az ifjúságügy ne problémaként jelentkezzen, elengedhetetlen egy kiszámítható finanszírozási rendszer kidolgozása.

- Megyénként nemcsak a megyei jogú városok jelentősek, de Kiskunfélegyháza, Szentes és Orosháza is kiemelkedő civil teljesítményekkel rendelkezik. Ha térképen ábrázoljuk az pályázatokhoz kapcsolódó szervezeti adatokat, akkor láthatjuk, hogy a bácsalmási, jánoshalmi és kunszentmiklósi (Bács-Kiskun); sarkadi, mezókovácsházi (Békés); csongrádi, kisteleki, makói (Csongrád) kistérségekben fontos, további feladatai vannak a regionális irodának. Az irodának kitüntetett figyelemmel kell fordulnia az ezekről a területekről érkező igények felé, akár egyéni kérésekről (európai önkéntes szolgálat); akár szervezetfejlesztéssel, akár forrásfelvétellel kapcsolatban érkezik.

- Elmondható, hogy dél-alföldi régió civil bázisa nagyon erôs és motivált, amit megerősítenek a Mobilitás és az NCA múködésének és pályázatainak információi és adatai is; bár a regionális különbségek itt is jellemzőek. Megoldást azonban önmagában egy regionális cselekvési-fejlesztési terv, az ifjúsági szcenárió szolgáltató rendszerének szorosabb, network-szerú együttmúködése és komolyabb állami források hiányában nem hozhat. Ezen együttmúködésben az úgynevezett hazai és nemzetközi mintaprojektek által (és alapján) történő fejlesztés, de serkentés és lendületbe hozás időszerúsége megkérdőjelezhetetlen. A „felnőtt világnak” a fejlesztési tervek kidolgozásába komolyabban be kell vonni az ifjúsági szcenárió résztvevőit, tulajdonképpen magát az ifjúságot. (E tematikában nem szúkíthetók le a fejlesztés irányai a turizmus és a szabadidő szcenárióra.)

- A regionális ifjúsági szolgáltató feladatokat ellátó iroda jelenlegi infrastruktúrája nagy vonalakban kielégítőnek mondható, a kubatúra azonban felvet némi problémát, elsősorban a helyigény (helyiségigény) megoldása a sürgető feladat (képzőtér, megfelelóen kialakított tájékoztató-ügyféltér nincs, s a jelenlegi irodai térszerkezet mellett azokat szinte lehetetlen létrehozni). 
- Az ifjúsági szolgáltató irodák (helyi és regionális) múködésének szakmai fejlesztési irányait meghatározhatják az úgynevezett Civil Szolgáltató Központokkal, a Teleházakkal és a települési önkormányzatokkal való fokozott kapcsolati rendszer kialakítása, és a helyi ifjúsági munka koordinációs szereplőjévé válás (katalizátor szerep). Mindehhez azonban az önkormányzatoknak (bizottsági, közgyúlési és polgármesteri szinten) és a politikai szereplőknek (egységesen) fokozott figyelmet kell fordítania a szervezett és a szervezeten kívüli ifjúságra egyaránt, a megfelelő és állandó források, tervezhető és kiszámítható pályázati lehetőségek biztosítására és ugyanakkor a hiányzó közösségi terek megteremtésére, fejlesztésére.

- Az önkormányzatok ifjúságpolitikai szervezeti felépítését vizsgálva megállapítható, hogy nagy különbség mutatkozik a településtípusok szerint. A nagyobb településeken sokkal jobban kiépültek az ifjúságpolitika szervezeti keretei.

- Megdöbbentő viszont azoknak a településeknek a magas aránya, akik nem is tervezik ifjúságpolitikai koncepció kialakítását. Az gyanítható, hogy az önkormányzatok a forráshiányos finanszírozás miatt nem tudnak energiát és pénzt fektetni az ifjúságpolitika szervezeti keretének kialakítására, ifjúsági koncepció kidolgozására. Ezt mutatja az a tény is, hogy azoknak az önkormányzatoknak a fele sem támogatja pénzzel az ifjúsági önkormányzatokat, amelyek múködési területén múködnek ilyenek.

- Általánosságban elmondható, hogy az ifjúságpolitika szervezeti kereteinek, koncepcióinak kiépítettsége még nem érte el a nyugat-európai szintet. 


\section{Swot-analízis}

Szerettük volna, ha a statisztikai adatok elemzésén túl, már az első verziókban is megfogalmazódnának az ifjúsági szakma számára fontos problémák, alapelvek, a szakemberek véleménye, elképzelései. Ezért a helyzetelemzést kiegészítettük a régió mindhárom megyéjéből érkező mintegy 50 szakember részvételével megrendezett regionális ifjúsági helyzetelemző múhelyben elkészített régiós ifjúsági SWOT-elemzéssel, az ott megfogalmazott főbb problémákkal, és kitörési pontokkal, amiket az iroda fejlesztő munkatársai kiegészítettek.

A DARISZI által szervezett Regionális Szakmai Múhely munkájába magas számmal csatlakoztak a Dél-alföldi Régió érintett szakemberei; önkormányzati munkatársak, ifjúsági referensek, ifjúsági civil szervezetek, ifjúság segítők, animátorok, ifjúsági, múvelődési intézmények munkatársai, teleház vezetők, KEF koordinátorok, szabadidő-szervezők, regionális tervezők, ifjúság kutatók, a DARISZI munkatársai. Aktivitásuknak köszönhetően szakmailag egy jó kezdetnek lehettünk részesei, jól alapozható kérdés - és problémakörök fogalmazódtak meg. A múhely menete a helyzetelemzés vitaanyagának bemutatása, a régiós helyzet közös elemzése, a főbb problémák, majd a lehetőségek mentén, a főbb kitörési pontok vázolása

A SWOT analízisben megfogalmazottak is alátámasztják azt a szakemberek által felvázolt kutatási eredményeket, melyeket a múhelymunkák előtt ismertettek a szociológus kutatók.

Néhány érdekes kérdéskörre, mint a média ereje, szerepe, lehetősége, civil szektor sajátosságai, kapcsolhatóság, szakmai szektor szerepe, lehetőségei... mégis rávilágít, amelyeket érdemes a későbbi kutatások folyamán felhasználni, elemezni.

Ennek eredményeként a résztvevő szakemberek a Dél-alföldi Régióban az alábbiakat tartják gyengeségnek, erősségnek, veszélynek és lehetőségnek ifjúsági kérdéskörben: 


\begin{tabular}{|c|c|}
\hline GY & \\
\hline $\begin{array}{l}\text { - általánosan, illetve ifjúsági téren is a } \\
\text { koncepciók hiánya: az önkormányzatok } \\
\text { nagy része problémaként kezeli az ifjú- } \\
\text { ságot, az ifjúság nem önálló szakágazat, } \\
\text { - a fiatalok közéleti passzivitása, a sze- } \\
\text { mélyiségfüggő aktivitásuk, a motiváció } \\
\text { és kommunikáció hiánya, a nyelvtudás } \\
\text { hiánya } \\
\text { - az önkormányzatok forráshiány miatt } \\
\text { jelentkező kényszerpályája e kérdéskör- } \\
\text { ben, a célcsoportra vetített forráshiányt } \\
\text { - az ifjúsági közösségi terek száma megle- } \\
\text { hetősen alacsony, gyenge a települések } \\
\text { megtartó erő (munkahely,...) } \\
\text { - a vegetáló civil szervezetek, } \\
\text { - a hálózati együttmúködés hiányát, illet- } \\
\text { ve az „régió tudat” hiánya (tervezési el- } \\
\text { lentmondások, ellenérdekeltségek...) } \\
\text { - a nem a valós célokkal/célcsoportokkal } \\
\text { foglalkozó civilek jelenléte, } \\
\text { - az oktatási intézmények közösségi neve- } \\
\text { lésre vonatkozó értékeinek hiánya. } \\
\text { - a régióban jelenlévő rossz közlekedés, a } \\
\text { fóvárostól való nagy távolság, (a földraj- } \\
\text { zi szinten megközelített) keleti határ- } \\
\text { mentiség, a tanyavilág megléte, } \\
\text { - az érdekképviselet hiánya középiskola } \\
\text { - atán, az ifjúsági irodák hiánya, } \\
\text { mánányzati ifjúsági bizottságok száma } \\
\text { liek száma, }\end{array}$ & 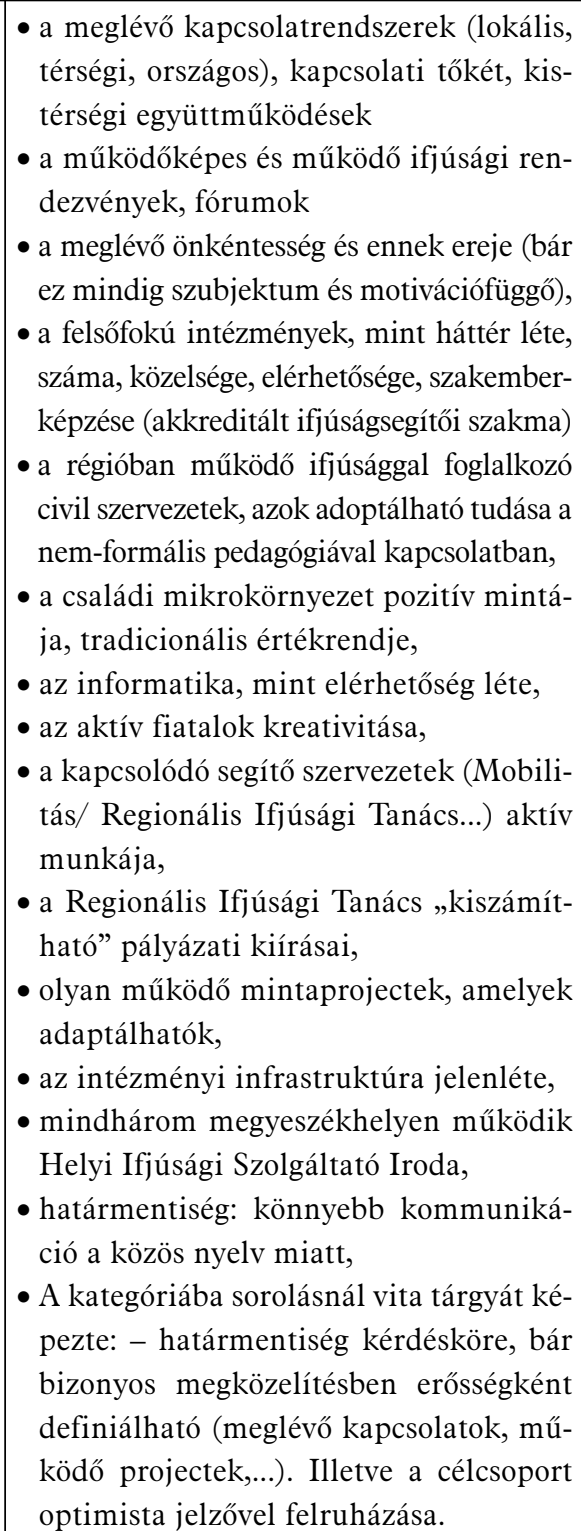 \\
\hline
\end{tabular}




\begin{tabular}{|c|c|}
\hline VESZÉLYEK & LEHETŐSÉGEK \\
\hline $\begin{array}{l}\text { - a MÉDIA, (mint a „megcsinált” } \\
\text { sztárok, a diszkók és a presztízsfo- } \\
\text { gyasztásra épülő áruvilág által alko- } \\
\text { tott, és folyamatosan fejlesztett, be- } \\
\text { határolt tér múködtetője), } \\
\text { - felülről irányítottan átpolitizált az } \\
\text { ifjúsági szektor (polarizáció) } \\
\text { • individualizált fiatalok, a kapcsola- } \\
\text { tok személytelenné válása (piacoso- } \\
\text { dás), a korosztályi elkülönülés (álta- } \\
\text { lános, közép, felsőfok, munka...) } \\
\text { - a fejlett országok/régiók elszívó ha- } \\
\text { tása (agyelszívás), nem itt hasznosul } \\
\text { a befektetett tudás, } \\
\text { - általánosan romló mentális állapot, } \\
\text { - a források rossz hasznosulása, } \\
\text { - középületek centralizáltsága, } \\
\text { • vidék elnéptelenedése. }\end{array}$ & $\begin{array}{l}\text { - a határmenti együttmúködést, } \\
\text { - a természeti értékeink kihasználásá- } \\
\text { val egyedi programok biztosítását, } \\
\text { - az ifjúsági irodák (Mobilitás), mint } \\
\text { információ szolgáltató központ akti- } \\
\text { vizálása, } \\
\text { - a civil háttér hatékony kihasználása, } \\
\text { - építeni és hatékony kihasználást ge- } \\
\text { nerálni a meglévő infrastruktúrák- } \\
\text { ban, } \\
\text { - a mintaprojectek adaptálása, nép- } \\
\text { - szerúsítése, elterjesztése, } \\
\text { - a testvérvárosi kapcsolatok erósítése } \\
\text { ifjúságpolitikai szempontból, } \\
\text { - az élethosszig tartó tanulás (LLL), } \\
\text { - és lehetôséget a MÉDIÁBAN, mint } \\
\text { a követendő példák, jó megoldások } \\
\text { népszerúsítóje. }\end{array}$ \\
\hline
\end{tabular}

A régió ifjúsági munkája szempontjából legégetőbb problémákat a résztvevők az alábbi két fő problémakörre osztották:

\begin{tabular}{|c|c|}
\hline Törvény és finanszírozás & Szervezés, Tervezés, marketing \\
\hline $\begin{array}{l}\text { - önkormányzati törvényból hiányzik } \\
\text { az ifjúsági feladatokról rendelkezố } \\
\text { rész (normatív támogatás hiánya } \\
\text { - ehhez rendelt források biztosítása } \\
\text { (forrásteremtés/elosztás) } \\
\text { - ifjúsági célú feladatok ellátása } \\
\text { (szakemberek) } \\
\text { - szakmásítás (felsőfokú) (módszer- } \\
\text { tanban!) } \\
\text { - tisztázatlan kompetenciák (párhu- } \\
\text { - zamok/átfedések) } \\
\text { - jogharmonizáció }\end{array}$ & $\begin{array}{l}\text { - közösségnélküliség (csatlakozás, be- } \\
\text { vonás) } \\
\text { • információ és hálózati együttmúkö- } \\
\text { dés hiánya } \\
\text { - motiválatlanság } \\
\text { - az önkormányzatok problémaként } \\
\text { kezelik az ifjúságot } \\
\text { - tisztázatlan szerepek, „régiótudat” } \\
\text { (érdekellentétek) } \\
\text { - leszakadó rétegek } \\
\text { - az oktatási rendszerek rugalmatlan- } \\
\text { sága a munkaeró piacon. }\end{array}$ \\
\hline
\end{tabular}




\section{KITÖRÉSI PONTOK}

Ebben a pontban a helyzetelemzésből kiolvasható, valamint regionális helyzetelemző múhelyben megfogalmazott kitörési pontokat egészítettük ki a RISZI fejlesztői munkatársainak véleményével. Figyelembe véve a vázolt, és kifejtett problémákat, az azokra adható válasz-lehetőségeket, a régió ifjúsági munkájának gyenge és erős pontjait, az alábbi kitörési pontokat fogalmazzuk meg.

A múhelymunkában résztvevők által megfogalmazott Kitörési pontok:

\section{Jogszabályi háttér megteremtése}

- Önkormányzati törvény módosítása. (Kötelező ifjúsági szakfeladatok, ifjúsági célok-normatív támogatás)

- Alkossa meg a parlament az ifjúsági törvényt. Rendeljen hozzá forrásokat!

A szakma ismertségének elismertségének erősítése

- Egyértelmú szakmai kompetenciák meghatározása (ifjúsági referens, ifjúság segítő, pedagógus...). A szakmai fogalomrendszer egyértelmú definiálása, ismertté tétele

- Az ifjúsági munka aktív médiajelenlétének megteremtése, erősítése.

- Kötelezni, kiszélesíteni a pozitív ifjúsági kezdeményezések propagandáját (sikeres közösségek bemutatása, lehetőségek, jó megoldások, programok ...).

- Pozitív sajtóvisszhang által az ifjúsági szervezetek presztízsének emelése (elfogadás önkormányzati, lokális szinten)

- Önkéntesség elismerése (motiváció)

- (bemutatni a fiatalok értékét, erősíteni)

- Szakmai elismerés lokális szinten, az adott település vezetői szintjén bevonás, érdekeltség felkeltése, elismerés.

Részben a múhelyben is elhangzottakat kiegészítve az alábbi kitörési pontokat tartjuk fontosnak leírni a dél-alföldi ifjúsági helyzetelemzésében:

\section{Helyi társadalom fejlesztése}

A helyi közélettől való elfordulás, a kormányzati, önkormányzati intézményrendszerből való kiábrándultság kezelésére alkalmas lehet olyan programok kezdeményezése és támogatása, amely az ifjúság bevonására irányul minden helyi társadalomfejlesztési folyamatba, amely a helyi generációs híd kiépíté- 
sére alkalmas fejlesztések, helyi kezdeményezések támogatásával együtt az öregedô dél-alföldi társadalom társadalmi összetartását is segíti, amelyhez a fiataloktól a társadalom részéről egyaránt elvárt, innovációs készség és a hagyományok ismeretének, tiszteletének egyensúlyát megteremtő programok támogatása erősít.

\section{A fiatalok aktív részvétele, ifjúsági kezdeményezések}

A tanulmány szerint a dél-alföldi fiatalok megdöbbentően jelentős része otthon (nagy valószínúséggel passzívan) tölti szabadidejének nagy részét.

Támogatni kell az olyan programok, rendezvények létrejöttét, ahol a fiatalok interaktív, alkotó módon vonódnak be az eseményekbe, nem pedig passzív, „fogyasztói” magatartást erősítik. Ez utóbbi veszély tapasztalható az ifjúsági fesztiválok, egyen-szolgáltóvá váló program kínálatában is.

\section{Települési és regionális identitás}

A 2000-ben létrehozott regionális ifjúsági szolgáltató iroda hálózat öt éve része a régió fejlesztő életének, beágyazottsága erős, regionális gondolkodása a tervezésben, fejlesztésben, a forráselosztási rendszerében is megmutatkozik. Mindezek miatt a RISZI az RFÜ-k komoly regionális társadalomfejlesztési tapasztalatokkal rendelkező, támogató partnere lehet a regionális tervezési prioritások közül a regionális identitás erôsítése prioritás programok nyelvére történő lefordításában.

Egészséges települési, és regionális identitás kialakítására lehetőséget biztosító, a fiatalok aktív részvételével zajló fejlesztő programok erősítése, újak kezdeményezése.

\section{Regionális ifjúsági és civil hálózatok erősítése.}

A régió fejlesztési tervének egyik prioritása a hálózatok létrejöttének támogatása, fejlesztése. Az ifjúsági terület regionális szinten múködő szakemberi, szervezeti, és szolgáltatási hálózattal rendelkezik (multiplikátorok, EuroDesk hálózat, ifjúsági referensek), és számos civil hálózattal tart folyamatos szakmai kapcsolatot (teleházak, ifjúsági irodák, CISZOK, Esélyek Háza). A RISZI-ben külön feladatként munkatárs foglalkozik a hálózatok fejlesztésével. Az iroda koordinálásban múköodik a Dél-alföldi Regionális Hálózatfejlesztôi Fórum. Mindezek jó alapot teremtenek ahhoz, hogy a regionális hálózatépítésben az említett hálózatokon és a RISZI-n keresztül az ifjúsági szervezetek is részt vállalhassanak. 
Ahogy a múhelyben is elhangzott, fontos feladat a

- szakértői hálózat generálása, fejlesztése;

- regionális hálózatok aktivizálása;

- szakmai egyeztetések az ifjúsági szakma képviselói között;

- regionális konzorciumi partnerségek erősítése.

\section{Nem-formális pedagógia megerősítése}

Az utóbbi évek kutatásaiból nyilvánvalóvá vált, hogy a munkaerôpiac igényeire, a társadalmi változások generálta képzési, nevelési kihívásokra az oktatási rendszer egyedül, önmagában képtelen megfelelni. Az oktatási intézmények szerepe gyengül, míg a kortárscsoportoké felerősödik. Számos a munkaerôpiacon, és az éltben nélkülözhetetlen egyéni és szociális kompetencia elsajátítására a kortárscsoportokban, iskolarendszeren kívül nyílik lehetőség. Ilyen az együttmúködés, tolerancia, érdekérvényesítés, tervezés, projektmenedzsment, interkulturális tanulás...stb

Erősíteni kell mindazon szereplőket (ifjúságsegítők, animátorok, nem-formális képzők, képző intézmények, szabadidő pedagógusok), tágítani a rendelkezésükre álló múködési teret, akik megteremtik a nem-formális tanulás környezetét. A kockázatvállalás erősítése (biztonságosabb közegben, kis lépésekkel), a tapasztalati tanulás útján, a nem-formális pedagógia, az ifjúságsegítés eszközeivel megtapasztalható. Az alkotó projekteken át megélt ifjú kort minden fiatal számára biztosítani kell.

\section{Információs társadalom}

A korosztály képviselői jórészt már az un. „screenager” generáció tagjai. Ügyesen, és nagy gyakorlattal használják az információtechnológia adta eszközöket. Elérésük, fejlesztésük egyik eszköze a virtuális közösségek építése, fejlesztése, amelyre az ifjúságsegítő szakembereket fel kell készíteni. Ez már most a jelenben is hatalmas kiaknázatlan kapcsolati és tudáshálózatokat jelent. Ez a folyamat az információhoz nehezen hozzáférók (kis települések, hátrányos helyzetû fiatalok) számára hordoz komoly veszélyeket. Itt az egyéni hozzáférések és a nyilvános közösségi hozzáférések támogatásával, fejlesztésével lehet előrelépni. Fontos, hogy az ezeket a feladatokat ellátó szervezetek, intézmények (Teleházak, eMagyarország pontok, könyvtárak) rendelkezzenek ifjúságsegítői ismeretekkel.

A DARISZI a DARFÜ-vel együttmúködésben fejlesztett regionális ifjúsági portálját tovább kell fejleszteni az ifjúsági szakemberek virtuális közösségi 
találkozási helyeként, ugyanakkor segíteni kell maguk a fiatalok virtuális közösségbe szerveződését is. Mindezeket szükséges lenne megjeleníteni a régió Információs Társadalomfejlesztési Stratégiájában.

\section{Eurorégió}

Régiónk egyik fó kitörési pontja a „Balkán kapuja” szerepkör. A jelenlegi is élő határokon átnyúló ifjúsági és civil kapcsolatok ennek a fejlesztési folyamatnak erős gerincét fogják képezni a jövőben, így ezeket meg kell erősíteni.

A Duna-Körös-Maros-Tisza Eurorégió széleskörú határmenti kapcsolatok építését teszi lehetővé. A kapcsolatteremtést erősíti a közös nyelv megléte. Az eurorégiós kapcsolatépítés lehetőségeit a jelenleginél nagyobb mértékben lehet kihasználni, ezt segíti a DKMT Eurorégió stratégiája, amelyhez jelen helyzetelemzés alapján készülő regionális ifjúsági koncepciót igazítani kell, hogy azzal egymás hatását erősíthessék. Építeni kell a határon átnyúló, már meglévő ifjúsági civil szervezeti hálózatra, a DKMT Eurorégió Ifjúsági Szövetségére.

Az ifjúsági szakemberek, a fiatalok között kiépülő kapcsolati, szervezetei hálózat, később gazdasági versenyelőnyöket is jelenthet. A kapcsolatépítési folyamat megerősítésének az Ifjúság 2000-2006 program a jelenleginél nagyobb mértékủ kihasználása is egyik eszköze.

Ezzel a kitörési ponttal a régió fejlesztési tervében is szereplő, határmenti, euroregionális együttmúködés erősítése kitörési lehetőséghez csatlakozna az ifjúsági terület.

Az eurorégiós civil kapcsolati hálózatot erősíti az a tény is, hogy a dél-alföldi régióhoz hasonlóan mind a vajdaságban, mind az erdélyi megyékben megtalálhatóak a teleházak, és az ifjúsági információs és tanácsadó irodáknak hálózatai. Ezek remek lehetőséget teremtenek az un. „tükör programok” lebonyolítására.

\section{Nemzetközi mobilitás}

A nemzetközi mobilitás nagyobb mértékú kihasználása, egyéni és közösségi szinten a régió fiataljai előtt már jelenleg is nyitva álló lehetőség. A fiatalok ezen a téren a testvér-települési kapcsolatokat, is újabb tartalommal tölthetik meg. Ez a kapcsolati tóke 5-10 éven belül a települések javát szolgáló, gazdasági előnyre váltható. Fontos lenne elérni, hogy a testvér-települési látogatások során, fiatalok, ifjúsági szakemberek, helyi ifjúsági párbeszédrendszerek 
képviselői is résztvevői legyenek egy-egy delegációnak. Az ehhez vezető út az ifjúsági munka önkormányzatokkal történő megismertetése, és hasznosságának elismertetése lehet.

Ezen a kitörési ponton belül kell erősíteni az ifjúsági szakemberek idegen nyelvtudását (különösen az angolt), számos nemzetközi programba emiatt félnek belevágni a szervezetek.

\section{Ifjúsági intézményi hálózat}

A meglévő ifjúsági intézményi hálózat erősítése nélkülözhetetlen a célok eléréséhez. Ilyen módon a regionális ifjúsági iroda mellett, szükséges minden nagyobb városban, a kistérségi központokban, kistérségi ifjúságfejlesztői identitással rendelkező ifjúsági információs és tanácsadó iroda létrehozásának, fejlesztésének támogatása. Ez részben az információhoz, mint a fiatalok életében nélkülözhetetlen tőkéhez való hozzáférés egyenlőbb és igazságosabb eloszlását tenné lehetôvé, másrészt befogadói lehetnének a legalább minden kistérségben múködő ifjúsági referensnek, egyben katalizátorai a kistérségi szintú ifjúsági kezdeményezéseknek.

\section{Forrásbővítés}

Az elemzés adataiból egyértelmúen kiderül, hogy az ifjúsági szervezetek forrásfelvevő képessége, a régióban lényegesen nagyobb, mint a jelenleg rendelkezésre álló keretek. Ezen a területen tehát van még szabad kapacitás, amire a jövőben építeni lehet.

Az Ifjúság 2000-2006 program népszerúsítésével részben az eseti ifjúsági kezdeményezések, több hónapon átívelő fejlesztési folyamatban való megerôsítése a cél, részben a nemzetközi mozgás elősegítése, a jó példák cseréje, partnerkapcsolatok kiépítése.

Továbbra is törekedni kell arra, hogy a Program forrásait a hátrányos helyzetû kistérségek is egyre inkább ki tudják használni, illetve, hogy a pályázó, pályázni tudó szervezetek köre bővüljön. A Youth Program keretében a kistérségi együttmúködésekben megvalósult ifjúsági kezdeményezéseken kialakult kapcsolati hálózatok később vidékfejlesztési programoknak alapjait is képezhetik, illetve érdemes lesz majd ezekbe bevonni a kistérség fiataljait. Ilyen szempontból érdemes megvizsgálni a Leader program és az ifjúsági kezdeményezések együttmúködési felületeit. 


\section{Ifjúsági közösségi terek fejlesztése}

A települési ifjúsági munkát vizsgálva a helyzetelemzés az elmúlt időszak beszúkölő intézményi lehetôségeiről beszél, a közösségi terek megszúnéséről. A korosztálynak a közéleti bevonódáshoz, a szabadidő kultúra fejlesztéséhez elkülönült korosztályi térre van szüksége. Ezeket az ifjúsági közösségi tereket újrateremteni, a meglévőket fejleszteni kell, mégpedig az ifjúsági szakma kritériumrendszerének szigorú érvényesítésével; alacsony küszöb, igazodó nyitva tartás, fiatalok bevonása, ergonómiai, biztonsági elóírások betartása, saját kezdeményezéseket támogató hely.

\section{Civil utánpótlás}

A régióban múködő civil szervezetek forrásfelvevésének egyik korlátja, a szervezeten belüli humánerőforrás utánpótlásának hiánya. Ez különösen a nagyobb forrásfelvevő potenciállal bíró szervezetekre igaz, így közvetve hatással van a régió forrásfelvételére is. Az szervezetek fejlesztése, a fiatalok e feladatra történő képessé tétele a régió ifjúsági szakembereinek fontos feladata. Ez az egyik legjelentősebb együttmúködési felület a RISZI, és az NCA között.

\section{Duna alsó szakaszának interregionális fejlesztése}

Az országos elemzések szerint a Duna alsó szakaszának kistérségei kevésbé fejlettek mindkét teljes régió (dél-alföld, dél-dunántúl) viszonylatában. Itt érdemes az ifjúságot is bevonva helyi társadalomfejlesztési folyamatokat kezdeményezni a dél-dunántúli régióval közösen. Ezen a folyamaton a DDRISZI, és a DARISZI közötti, több éves ifjúságfejlesztési szakmai kapcsolat sokat lendíthet.

\section{A tanyavilág fiataljai}

A régió egyik jellegzetessége a tanyán élők nagy száma, különösen Bács-Kiskun megyében. A tanyán élő fiatalok összetartozásának, közösségének erősítése, tanyai ifjúsági közösségi terek teremtésével lehetséges. Meglévő, „volt Klebelsberg iskolaépületek" felújításának, közösségi térré, tudásházzá alakításának támogatása, ezekben teleházak, és nem-formális képző helyek kialakítása szükséges. 


\section{A tanyavilág fiataljai}

A régió egyik jellegzetessége a tanyán élők nagy száma, különösen Bács-Kiskun és Csongrád megyében. A tanyán élő fiatalok összetartozásának, közösségének erősítése, tanyai ifjúsági közösségi terek teremtésével lehetséges. Meglévő, „volt Klebelsberg-iskolaépületek” felújításának, közösségi térré, tudásházzá alakításának támogatása, ezekben teleházak, és nem-formális képző helyek kialakítása szükséges. ${ }^{38}$

\footnotetext{
${ }^{38}$ A tanyán elszigetelten, nagyon nehéz szociális körülmények között élő családok esetében a gyermekszegénység tetézve az ingergazdag környezet hiányával, illetve a kulturális és szabadidős tevékenységek tartalmas végzése helyének hiányával és általában az elszigeteltséggel különösen komoly következményekkel jár a jelenre és a jövőre nézve egyaránt. Nagyon fontosnak tartjuk mindezen sajátos problémák orvoslását. Szükség van speciális programokra, mint például a tanyai iskolabusz járatok indítása, a tanyai szolgáltató központok kialakítása, valamint a szociális szolgálatok fejlesztésére, a hatékony működés feltételeinek megteremtésére. A speciális programok szükségességét ezek az adatok és az eddigi tapasztalatok is alátámasztják, hosszútávon azonban célszerú bizonyos feladatok nem programszerü, hanem folyamatos biztosítása. E helyütt mondunk köszönetet Matula Anikónak a Homokhát Eurointegráció Kht. ügyvezetőjének, e témakörben tett megjegyzéseiért.
} 


\section{Felhasznált irodalom}

[1] Azzopardi, A. - Furlong, A. - STALder, B.: Sebezhető ifjúság. Sebezhetóség az oktatásban, a munkavállalásban és a szabadidóben Európában. Belvedere, 2003

[2] Bódi GYÖRGY - Jung AdrIENN - LAKROvits ElvíRA: Civil parterség. KJK-Kerszöv, 2003

[3] Csatári Bálint - Lengyel Imre - Nagy Imre - Nagy Gábor: A Dél-alföldi Régió Területfejlesztési koncepció felülvizsgálata. DARFT - MTA, 2005

[4] Clarke, J. - JefFerson, T:: A munkásosztály ifjúsági kultúrái. Gábor Kálmán: A középosztály szigete. [szerk. Jancsák Csaba] Belvedere, 2000, 2001, 115-117

[5] DÉL-ALFöLDI Regionális Egészségfejlesztési Program Helyzetfelmérés, EM Csoport Kht.

[6] DÉL-ALFöldi Régió Helyzetelemzés. 2005.05.06 (2. számú munkaanyag) (www.del-alfold.hu)

[7] GábOR Kálmán: A középosztály Szigete. [szerk. Jancsák Csaba], Belvedere, 2000, 2001

[8] Gábor Kálmán: Fesztiválok ifjúsága és a drog. [szerk. Jancsák Csaba és Tarnay István], Belvedere, 2005

[9] Gábor Kálmán - KABAi ImRE - MATiscsák AtTila: Információs társadalom és az ifjúság. Belvedere, 2003

[10] IfJúsÁG 2000 Gyorsjelentés [szerk. Bauer Béla et. al.], 2001

[11] IfJúsÁg 2004 Gyorsjelentés [szerk. Bauer Béla et. al.], 2005

[12] IfJúsáG 2004 kutatás összefoglaló adatai (a Mobilitás hozzájárulásával)

[13] Ifjúsági korszakváltás - Ifjúság az új évezredben. [szerk. Gábor Kálmán és Jancsák Csaba] MTA SZKI - PH FOK - Belvedere, 2004

[14] Ifjúságpolitikák. [Szerk.: Tamás Pál és Tibori Tímea] ÚMK - MTA SZKI, 2005

[15] MANDA EszTER: Alkohol-, nikotin és drogfogyasztás alakulása a fiatalok körében Szegeden. www.mave.hu

[16] NaGY LÁsZLÓNÉ: Önpusztító szenvedélyek veszélye a középiskolások között mért kutatási adatok tükrében In: Egészségnevelés 2000/41, 127-131

[17] NÉPSZÁmLÁLÁsI adatok, 2001 (KSH)

[18] NonProfiT szervezetek Magyarországon. KSH, 2000

[19] Szabó Andrea - Kovács Szilvia - Bitter Brúnó - Bauer Béla: Gyermek-, múvelődési és ifjúsági házak. 2001, 2002

[20] TAmás PÁL: Gyökerek és szárnyak. Avagy a szolidaritás átrendeződése. In.: Ifjúságpolitikák. Új Mandátum - MTA SZKI, 2005, 240-251

[21] Társadalmi átalakulás és ifjúság - A szabadság mint esély. [szerk. Gábor Kálmán], Belvedere, 1999, 2000

[22] A társadalmi búnmegelózés nemzeti stratégiája (Melléklet a 115/2003. (X.28.) OGY. határozathoz

[23] JogSZABÁlYoK: www.mkogy.hu; NÉPESSÉGi ÉS REgIONÁlis STATISZTIKÁK: www.nepszamlalas.hu; www.ksh.hu; REGIONÁLIS ADATOK: www.del-alfold.hu; www.dkmt.hu; www.bacskiskun.hu; www.bekesmegye.hu; www.csongrad-megye.hu; www.mave.hu; www.nca.hu; istar.nkom.hu; MOBILITÁS DARISZI adatbázisai 


\section{A kötet szerzői}

Jancsák Csaba (Tatabánya, 1972): A Juhász Gyula Tanárképző Főiskolán magyar-történelem és pedagógia szakon végez $(1995,1998)$, majd a Szegedi Tudományegyetem szociológia szakán 2000-ben. A szegedi Kiss Ferenc Erdészeti Szakközépiskolában nevelőtanár (1995-96), JGYTF Hallgatói Önkormányzat elnöke (1996-99), SZTE Egyetemi Hallgatói Önkormányzat elnöke (2000-2002), majd a Hallgatói Iroda vezetője (20022004). 2004-től a Szegedi Tudományegyetem oktatója. Az Európai Ifjúsági Kutató-, Szervezetfejlesztő és Kommunikációs Központ igazgatója. Az MTA Szociológiai Kutatóintézet, a Felsőoktatási Kutatóintézet és a Belvedere Meridionale „Ifjúsági korszakváltás” címú könyvsorozatának szerkesztőbizottsági tagja. A madridi székhelyú Nemzetközi Szociológiai Társaság (ISA) tagja.E-mail: jancsak@jgytf.u-szeged.hu

Tarnay István (Szeged, 1980): A Szegedi Tudományegyetem Bölcsészettudományi Karán szociológia szakon végzett 2004-ben. 2003-tól az Oktatáskutató Intézet, majd 2004tôl a Felsőoktatási Kutatóintézet ifjúságkutató csoportjának gyakornoka, 2005-től az Európai Ifjúsági Kutató-, Szervezetfejlesztő és Kommunikációs Központ kutatója. A Magyar Szociológiai Társaság tagja.E-mail: tarnay.istvan@ifjusagkutatas.hu

Vajda Árpád (Dunaújváros, 1967): A József Attila Tudományegyetem Természettudományi Karán végez biológia-kémia szakon 1967-ben, majd 1997-ben, a szegedi Euromenedzser Vezetőképző Intézetben humánerőforrás menedzser szakképzettséget szerez. 1992-től a Szegedi Ifjúsági Házban kulturális menedzser. 1997-től a szegedi SZITI iroda vezetője. 1999-tôl humánerőforrás vezető a Szilánk üvegipari vállalatnál. 2001-től tanácsadói-hálózatvezető a Magyar Teleház Szövetségnél. 2004-től a Mobilitás Dél-alföldi Regionális Ifjúsági Szolgáltató Iroda irodavezetője. E-mail: vajda.arpad@mobilitas.hu

Závogyán Magdolna (Szarvas, 1970): A Szegedi Juhász Gyula Tanárképző Főiskola Müvelődésszervező Szakán művelődésszervező, menedzser, média szakirányon, és a Debreceni Egyetem Bölcsésztudományi Karán művelődésszervező, felnőttoktatási és felnőttképzési szakon végzett. 1992-től a Faluszépítő Baráti Társaság elnöke, 2001-től a Dél-alföldi Regionális Ifjúsági Szolgáltató Iroda, 2004-tôl Gyermek- ifjúsági és Sportminisztérium pályázati szakértője. 2004-től a Magyar Teleházszövetség Egyesület Délalföldi regionális tagozat Felügyelő Bizottságának elnöke, mentora. 2004-től a Nemzeti Civil Alapprogram Dél-alföldi Kollégiuma tagja, 2005-től Civil Közösségi Házak Országos Egyesületének az elnöke.E-mail: kondorositelehaz@freemail.hu 


\section{Summary}

As a part of the second National Development Plan concerning the period between 2007 and 2012 several planning procedures of great importance are proceeding, for which the „Hálózat a Szabad Információért Alapítvány” [Network for Free Information Foundation], „Duna-Körös Maros-Tisza Eurorégió Ifjúsági Szövetsége” [Youth Alliance of the Euroregion Danube-Kris Mures-Tisa], „Európai Ifjúsági Kutató-, Szervezetfejlesztő és Kommunikációs Központ” (EIKKA) [European Youth Centre of Research, Organisation Development and Communication] and the „Mobilitás Dél-alföldi Regionális Ifjúsági Szolgáltató Irodája” (DARISZI) [Youth Service Office of Mobility in the Region Southern Great-Plain] have established a research consortium, and it has taken up the job to analyse the situation of the youth in the region with the cooperation of youth experts of the region.

One of the most important goals of the research was to achieve that the problems and chances that were discovered during the situation analysis shall be presented in the planning procedures in a systematized way. This way we would have liked to achieve - in a broader sense - that the civil organisations, local governments, institutions and experts that deal with the youth obtain more help and resources in the future so that they could manage their job, which enables the generation that is growing up to responsibly form their own future.

The situation analysis was carried out partly by second-analysing the relevant literature, database and statistics, furthermore, by using the results of the great model youth research called Ifjúság 2000 [Youth 2000] and Ifjúság 2004 [Youth 2004], while the questionnaire regarding the local youth work and the youth civil scenario was carried out by the help of the EIKKA and the DARISZI.

In addition to the sociological analysis, we intended to outline the problems, principles and the opinion and ideas of the experts that are relevant to the science of youth just right at the beginning. In order to achieve this goal, the situation analysis was expanded by the outlined main problems, by the break-out points and by a regional youth SWOT-analysis, which was carried out by 50 experts from all three counties of the region (employees at local governments, youth referents, representatives of the Harmonizing Forum for Drug Affairs, free-time organizers, regional planners, researchers).

As a result of this, the analysis of the situation of the youth in this region has pointed out that the processes relating to the youth are similar to the social changes that are proceeding in the European Union in this field. The aging society, the expanded time spent studying, the higher number of young people that study, and on the other hand, the lower number of the active young people who are employed, the requirements of the labour market, the youth education, the vulnerability regarding the labour market and free-time, the disappointment about the institutional system and the fact that the young people have explicitly turned away from playing an active role in public life put the Member states of the European Union to redefine the governmental actions in connection with the youth in the so called "White Paper on Youth Policy”.

The features of the region Southern Great Plain that are outlined in the analysis show warning results that the young people in this region are in a worse situation in more fields as compared to the youth in the other regions of the country.

The study points out the higher number of students by presenting the situation of the young people in this region, which affects the other dimensions that were examined, resulting in the lower number of the active young people who work and the increasing number of young students. It can be said that the situation of the young people has deteriorated in general, because they are in a worse situation regarding their financial state and their living facilities than four years ago. In addition, the number of the youth unemployed has been increasing. The change in the living facilities points out that it is more and more difficult for a young person to get a flat; however, the increase in the number of students might have caused the above-mentioned changes, as well. Especially in order to be able study in the higher education, students have to move into another town, and this fact may be a reason for the decline in the number of young people who own a flat or who live with their parents.

The young people do not have more free-time, even though the number of the students has increased. This shows that a kind of competition has developed in the education and on the labour market, which forces the students to train themselves outside the formalized educational system, too, which they do in their free-time. 
On the basis of the experience obtained in connection with applications aiming at this sector it can be stated that there is an extremely huge demand for programme financing, for the assets development as well as for the specific and camp ones among the programmes. We have found that the demand was the hugest in relation to these goals, and similar demands must be expected to appear on the part of the organisations dealing with child and youth policy.

It can be stated that the civil base of the Southern Great Plain Region is in general quite strong and motivated, which is confirmed by the information and data obtained from the operation and the applications of the „Mobilitás” [Mobility] and the „Nemzeti Civil Alapprogram” (NCA) [National Civil Base-programme], and the regional differences were obviously characteristic in this field, as well. However, no solution can be achieved without a regional action-development plan, without the stronger and network-like cooperation of the service system of the youth scenario and without state resources. In this cooperation it is indisputable that it is high time that the so called national and international model projects (in addition, on the basis thereof) developed, stimulated and gave an impulse. The "adults” shall take the representatives of the youth scenario into the working-out of the plans, actually the youth itself. (In this thematic, the fields of the development cannot be limited to the scenario of tourism and free-time.)

The up-to-date infrastructure of the office that carries out the regional youth service tasks is more or less satisfactory; however, the cubage raises some problems, first of all the demand for space (demand for room), and it is a really urgent task to solve this problem (there is no training room, no adequately established room for dealing with and informing the clients, and considering the actual office place structure it is almost impossible to establish these rooms).

The professional development orientation according to which the youth service offices (local and regional) operate could be determined by establishing a more intensive contact system with the so called Civil Service Centres [Civil Szolgáltató Központ], the Tele-houses [Teleház] and the municipal local governments, that is, by becoming a coordinating participant in the local youth work (role of a catalyzer). In order to achieve all this, the local governments (on the level of the committees, the general assembly and the mayor) and the representatives of the politics should pay attention to both the youth in organisations and outside an organisation, to provide the adequate and permanent resources, the application opportunities that one can plan and compute, furthermore, to establish and to develop the missing community rooms.

By analysing the organisational structure of the youth policy of the local governments it can be stated that there is a great difference between the municipalities on the basis of the type of the municipality. In the big municipalities the organisational frameworks of youth policy are better established. However, the high number of the municipalities that do not plan to establish their youth policy concepts was rather astonishing. It can be assumed that the local governments cannot spend the required energy and time establishing the organisational frameworks of their youth policy, a concept for youth policy in the lack of financial resources. This is also confirmed by the fact that less than $50 \%$ of those local governments provide financial support for youth policy governments that operate within the territory thereof. In general it can be stated that the organisational frameworks of youth policy and the level on which its concepts are established has not reached the WesternEuropean level yet.

The experts of the youth in this region have divided the field of youth into two major types of problems. On one hand, there is a lack of regulations that define the regulation more unambiguously than the law does it at the moment how the local governments shall carry out their tasks related to youth policy. On the other hand, the profession concerning the youth is not well-known and acknowledged to a small extent, and the ability of the profession to represent its interests is not of great importance.

Among the break-out points defined in the situation analysis we would like to highlight the importance of involving the young people and the people dealing with the youth in the local society development processes, supporting the organisations and experts that establish an atmosphere which stimulates international mobility and studying outside the educational system.

Special areas within the region are the young people living in the suburbanizing municipalities, on the detached farms in the country and in the lower part of the Danube. Joining the most important break-out point of the Southern Great Plain region, it is important for the profession dealing with the youth, as well, to catalyze the cooperation in the Danube-Kris-Mures-Tisa Euroregion. 